Bryn Mawr College

Scholarship, Research, and Creative Work at Bryn Mawr College

Classical and Near Eastern Archaeology Faculty

Research and Scholarship

Classical and Near Eastern Archaeology

1990

\title{
The Nemea Valley Archaeological Project: A Preliminary Report
}

James C. Wright

Bryn Mawr College, jwright@brynmawr.edu

J.F. Cherry

J.L. Davis

E. Mantzourani

S. B. Sutton

See next page for additional authors

Let us know how access to this document benefits you.

Follow this and additional works at: http://repository.brynmawr.edu/arch_pubs

Part of the Classical Archaeology and Art History Commons, and the History of Art, Architecture, and Archaeology Commons

\section{Custom Citation}

Wright, James C., John F. Cherry, Jack L. Davis, Eleni Mantzourani, Susan B. Sutton, and Robert F. Sutton Jr. 1990. The Nemea Valley Archaeological Project: A Preliminary Report. Hesperia 59:579-659.

This paper is posted at Scholarship, Research, and Creative Work at Bryn Mawr College. http://repository.brynmawr.edu/arch_pubs/95

For more information, please contact repository@brynmawr.edu. 
Authors

James C. Wright, J. F. Cherry, J. L. Davis, E. Mantzourani, S. B. Sutton, and R. F. Sutton 


\section{THE NEMEA VALLEY ARGHAEOLOGIGAL PROJECT}

\section{A PRELIMINARY REPORT}

(Plates 93-97)

\section{INTRODUCTION}

\section{HE FOCUS OF ARCHAEOLOGICAL RESEARCH on regions rather than sites has a long history in Greece, ${ }^{1}$ beginning around the turn of the century with work in}

${ }^{1}$ The Nemea Valley Archaeological Project is sponsored by Bryn Mawr College and has worked under the auspices of the American School of Classical Studies at Athens with permissions from the Ministry of Culture and Sciences from 1984 through 1989.

For advice and support we thank Dr. Ioannis Tzedakis, Director of Prehistoric and Classical Antiquities; Professors Stephen G. Miller and William D. E. Coulson, successive Directors of the American School of Classical Studies; Dr. Phani Pachygianni, Ephor of Prehistoric and Classical Antiquities, Nauplion Museum, and Ms. Eleni Palaeologou, who served in that capacity during the early years of the project. Ms. Zoe Aslamatzidou and Ms. Eleni Korka facilitated our research in the field, while Mr. Andreas Vakrinakis, Head Guard at the Nemea Museum, and his staff of guards extended to us every courtesy in use of the museum. Professor William R. Biers generously facilitated our work at Phlius. Special thanks are due also to the villagers of Ancient Nemea and Ancient Kleonai for their unstinting philoxenia and to successive mayors of Ancient Nemea, Evangelis Zaimis and Nikolaos Papadopoulos, and the Secretary of the village, Andreas Mouschouras.

The project has received major funding from the National Endowment for the Humanities (matching grant RO 20731 and outright grant RO 21715), the Institute for Aegean Prehistory (grants in 1984, 1985, 1986, 1987), and the National Geographic Society (Grants 2971-1984, 3265-1986). Generous private donations were made by Mr. William Broekhuysen in honor of his wife Elizabeth and by Alwyn Carus, Elisabeth Carus, Frances F. Jones, Lucien Levy, Rueben Resnick, James H. and Margaret G. Wright, and Carl Youngdale.

Acknowledgments for assistance are given below under appropriate sections. All illustrations except Figures 4 and 11 were drawn or inked by Julia E. Pfaff. Photographs are by Taylor Dabney except for Plate 94:f and $\mathrm{g}$, which are from the archives of James P. Harland.

The following abbreviations for archaeological phases are used:
$\mathrm{A}=$ Archaic
$\mathrm{BA}=$ Bronze Age
Byz = Byzantine
$\mathrm{HL}=$ Hellenistic
$\mathrm{C}$ = Classical
$\mathrm{L} \quad=$ Late
$\mathrm{E} \quad=$ Early
$\mathrm{F} \quad$ = Final
$\mathrm{G} \quad=$ Geometric
$\mathrm{H}=$ Helladic
$\mathrm{M}=$ Middle
$\mathrm{N}=$ Neolithic
Ott = Ottoman
$\mathrm{P} \quad=$ Proto
$\mathrm{R}=$ Roman
$\mathrm{T}=$ Turkish

In discussing phases, an en dash is used for inclusive phases, e.g., A-C, R-Byz, and a solidus when ambiguity in the phase is expressed, e.g., A/C, R/Byz.

Works frequently cited are abbreviated as follows:
Biers, 1969
Biers, 1971
= W. R. Biers, "Excavations at Phlius, 1924," Hesperia 38, 1969, pp. 443-458
Binford
=W. R. Biers, "Excavations at Phlius, 1924: The Votive Deposit," Hesperia 40, 1971, pp. 397-423
Blegen, 1931
$=$ L. R. Binford, "A Consideration of Archaeological Research Design," American An- tiquity 29, 1964, pp. 425-441 = C. W. Blegen, "Gonia," Metropolitan Museum Studies 3, 1931, pp. 55-80 
Melos, Lakonia, Thessaly, and elsewhere. ${ }^{2}$ These researches established archaeological sequences, defined regional artifact and settlement types, and provided an overview of settlement from prehistoric times on. After World War II a series of extensive, but more systematic, surveys in many areas of the country was conducted by R. Hope Simpson and colleagues. ${ }^{3}$ Meanwhile a continuing tradition of geographic studies described natural as

Blegen, 1975

Cherry et al., 1988

Cherry et al., Archaeological Landscape

Cook

Dickinson

Edwards

Faraklas

French

Harland

Kolodny

McGrew

Miller, 1975

Miller, 1976

Miller, 1980

Miller, 1982

Mouzelis

Pritchett

Redman

Russell

Rutter

Wagstaff

Wiseman

Wright et al., "Early Mycenaean Settlement"
= C. W. Blegen, “Neolithic Remains at Nemea," J. L. Caskey, ed., Hesperia 44, 1975, pp. 251-279

$=$ J. F. Cherry, J. L. Davis, A. Demitrack, E. Mantzourani, T. F. Strasser, and L. Talalay, "Archaeological Survey in an Artifact-Rich Landscape: A Middle Neolithic Example from Nemea, Greece," AJA 92, 1988, pp. 159-176

= J. F. Cherry, J. L. Davis, and E. Mantzourani, The Archaeological Landscape of Northern Keos in the Cyclades, UCLAMon, forthcoming

= J. M. Cook, “Mycenae 1939-1952, III. The Agamemnoneion,” BSA 48, 1953, pp. 30-68

$=\mathrm{O} . \mathrm{T} . \mathrm{P} . \mathrm{K}$. Dickinson, "Parallels and Contrasts in Mycenaean Civilisation on the Mainland," Oxford Journal of Archaeology 1, 1982, pp. 125-137

$=$ G. R. Edwards, Corinth, VII, iii, Corinthian Hellenistic Pottery, Princeton 1975

$=$ N. Faraklas, Ancient Greek Cities, XI, Phleiasia, Athens 1972

= E. French, "The Figures and Figurines," in The Archaeology of Cult, A. C. Renfrew, ed. (BSA Suppl. 18), London 1985, pp. 209-280

$=\mathrm{J}$. P. Harland, "The Excavations of Tsoungiza, the Prehistoric Site of Nemea," AJA 32,1928 , p. 63

$=$ E. Kolodny, La population des îles de la Grèce, Aix-en-Provence 1974

= W. W. McGrew, Land and Revolution in Modern Greece, 1800-1881, Kent, Ohio 1985

= S. G. Miller, “Excavations at Nemea, 1973-1974," Hesperia 44, 1975, pp. 143-172

= S. G. Miller, "Excavations at Nemea, 1975," Hesperia 45, 1976, pp. 174-202

= S. G. Miller, "Excavations at Nemea, 1979," Hesperia 49, 1980, pp. 178-205

= S. G. Miller, "Excavations at Nemea, 1981," Hesperia 51, 1982, pp. 19-40

$=$ N. P. Mouzelis, Modern Greece: Facets of Underdevelopment, New York 1978

= W. K. Pritchett, Studies in Ancient Topography, Part II (Battlefields). (University of California Publications in Classical Studies 4), Berkeley 1969

= C. Redman, "Surface Collection, Sampling and Research Design: A Retrospective," American Antiquity 52, 1987, pp. 249-265

= A. G. Russell, "The Topography of Phlius and the Phliasian Plain," University of Liverpool Annals of Archaeology and Anthropology 11, 1924, pp. 37-47

$=$ J. B. Rutter, "Pottery Groups from Tsoungiza of the End of the Middle Bronze Age," Hesperia 59, 1990, pp. 375-458

$=\mathrm{M}$. Wagstaff, The Development of Rural Settlements, London 1982

$=\mathrm{J}$. Wiseman, The Land of the Ancient Corinthians (SIMA 50), Göteborg 1978

$=$ J. C. Wright, J. F. Cherry, J. L. Davis, and E. Mantzourani, "Early Mycenaean Settlement in the Nemea Region," in The Prehistoric Aegean and Its Relations to Adjacent Areas, Proceedings of the Sixth International Colloquium on Aegean Prehistory, G. Korres, ed., Athens, in press

${ }^{2}$ E.g., D. Mackenzie, “Ancient Sites in Melos," BSA 3, 1897, pp. 71-88; R. M. Dawkins et al., "Laconia," $B S A 13,1906-1907$, pp. 1-284; 14, 1907-1908, pp. 1-182; 15, 1908-1909, pp. 1-213; 16, 1909-1910, pp. 1-75; and A. J. B. Wace and M. Thompson, Prehistoric Thessaly, London 1912.

${ }^{3}$ R. Hope Simpson, "Identifying a Mycenaean Site," BSA 52, 1957, pp. 231-259; H. Waterhouse and R. Hope Simpson, "Prehistoric Laconia: Part One," BSA 55, 1960, pp. 67-107; eidem, “—_, Part Two," 


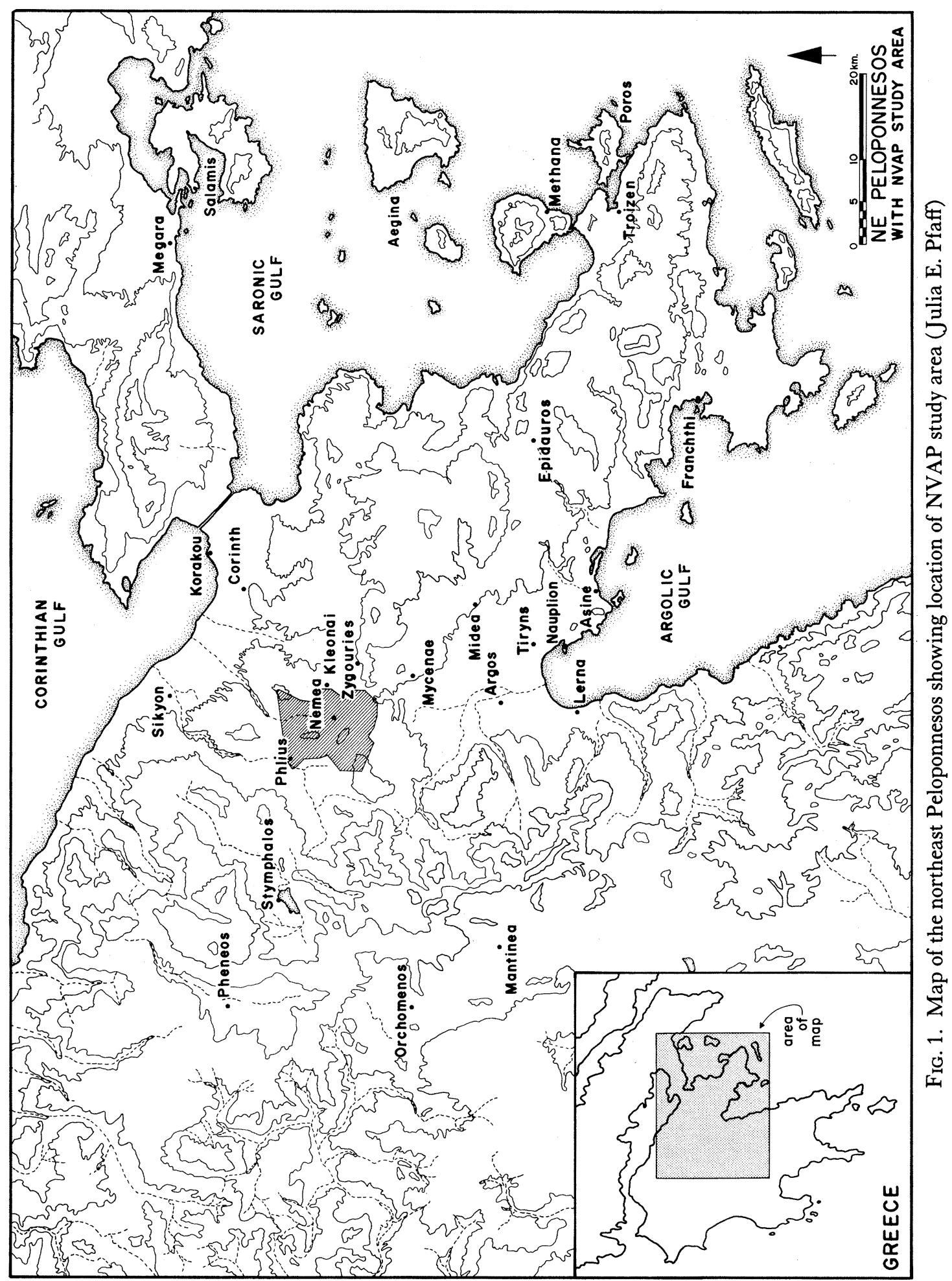


well as cultural landscapes and studied the impact of the distribution of resources on the demographic and economic basis of settlement in Greece. ${ }^{4}$ Recent work has been strongly influenced by advances in method, theory, and research design made outside Greece during the 1960's and 1970's, ${ }^{5}$ and it is now normal to attempt to integrate socio-economic, political, geographical, and ecological variables. Such work assumes that an understanding of human behavior can benefit from looking beyond single settlements and that regional studies enable us to see the wider context of many activities concerned with land use and settlement. The resulting information on variations in long-term exploitation of local resources, the varied relationships of different settlements within a region to one another, and the interaction between the region and the outside world does much to help us disentangle the causal factors of the settlement and land-use patterns which are a primary concern of much archaeological research.

Central to many recent regional studies is the concept of cultural ecology, namely the identification and study of the processes by which a human group adapts to a particular environment, both natural and social. ${ }^{6}$ Such an approach to regional studies stresses the study of exploitative and productive technologies and the analysis of behavioral adaptations to the natural environment, as manifest, for example, in patterns of settlement and land use. All natural landscapes have some potential for exploitation, yet the technological means for doing so do not remain constant and are conditioned by an ever-changing social matrix. ${ }^{7}$ Archaeologists have thus been challenged to devise research strategies that result in comprehensive explanations of culture change. One consequence of these new approaches to regional archaeology is the need for sensibly and unambiguously delimited study areas, the use of appropriate sampling schemes, and a strong emphasis on recognizing recurrent patterns of archaeological evidence which emerge clearly only over the long duration. The building of models to understand such patterns can often be significantly advanced by the anthropological and ethnohistorical study of more recent adaptations to the same region. ${ }^{8}$

$B S A$ 56, 1961, pp. 114-175; W. A. McDonald and R. Hope Simpson, "Prehistoric Habitation in the Southwestern Peloponnesos," $A J A$ 65, 1961, pp. 221-260; eidem, "Further Exploration in the Southwestern Peloponnesos," AJA 68, 1964, pp. 229-245; and eidem, "Further Exploration in the Southwestern Peloponnesos," AJA 73, 1969, pp. 123-177; R. Hope Simpson, A Gazetteer and Atlas of Mycenaean Sites (BICS Suppl. 16), London 1965. For a general discussion, see J. Bintliff, "The History of Archaeo-geographic Studies of Prehistoric Greece, and Recent Fieldwork," in Mycenaean Geography, J. Bintliff, ed., Cambridge 1979, pp. 3-16.

${ }^{4}$ E.g., H. Lehmann, Argolis, Athens 1937; A. Philippson, Die griechische Landschaften, E. Kirsten, ed., vols. 1-5, Frankfurt 1959; Kolodny; J. Bintliff, Natural Environment and Human Settlement in Prehistoric Greece (BAR Supplementary Series 28), Oxford 1977; Wagstaff.

${ }^{5}$ Binford; C. Redman, "Multistage Fieldwork and Analytical Techniques," American Antiquity 28, 1973, pp. 61-79; Redman.

${ }^{6} \mathrm{~J}$. Steward, Theory of Culture Change, Urbana 1955, pp. 40-42.

${ }^{7}$ L. R. Binford, “Archaeology as Anthropology," American Antiquity 28, 1962, pp. 217-225; Binford; A. C. Renfrew and J. Wagstaff, edd., An Island Polity, Cambridge 1982.

${ }^{8}$ For research design and sampling, see Binford; Redman; for ethnoarchaeology, see T. W. Jacobsen, "Another Modest Proposal: Ethnoarchaeology in Greece," in Contributions to Aegean Archaeology. Studies in Honor of William A. McDonald, N. C. Wilkie and W. D. E. Coulson, edd., Minneapolis 1985, pp. 91-107. 
While many projects in the Americas and the Near East have taken this new methodology to heart, ${ }^{9}$ archaeology in Greece has been slower to respond to the challenge. The influential Minnesota Messenia Expedition, however, laid the foundations for more scientific and interdisciplinary regional studies in Greece, ${ }^{10}$ while the more recent Melos project has squarely met the goals of a cultural ecological approach within a manageable and coherent study area. ${ }^{11}$ There a probabilistic sampling strategy for an intensive survey significantly advanced regional studies in Greece, ${ }^{12}$ while the attention paid to the systemic nature of inter- and intra-regional activities and to the response of the Melians to economic and political changes both on and beyond the island since its first settlement has strongly influenced our own work at Nemea as well as a number of other large-scale projects that have just been completed or are in progress. ${ }^{13}$ In addition to these developments, cooperation with social anthropologists, geoarchaeologists, and historical ecologists has now become a regular feature of such studies.

The primary goal of NVAP has been to document and explain changes in patterns of settlement and land use at all times in the past within a small region of approximately 80 sq.km. in southern Greece, centered on the Nemea Valley. ${ }^{14}$ Although best known as the location of the Classical sanctuary of Zeus, Nemea has a long history of occupation, extending far back into prehistoric times. Our decision to explore this area was greatly influenced by previous archaeological and historical research that suggested that the Valley and its surroundings have rarely been the locus of an independent polity but more often were drawn under the domination of neighbors. Nemea appears to have been exploited by a variety of external centers and to have been incorporated into political economies of differing organization and complexity at various times in its history.

It was this demonstrable vulnerability to the powers of the outside world that, in our eyes, made the Nemea Valley an ideal candidate for a study of long-term change in the

${ }^{9}$ E.g., R. McC. Adams, Heartland of Cities, Chicago 1981, in southern Mesopotomia; R. E. Blanton, S. A. Kowaleski, G. Feinman, and J. Appel, Ancient Mesoamerica: A Comparison of Change in Three Regions, Cambridge 1981, in the Valley of Oaxaca, Mexico; and J. R. Parsons, "The Development of a Prehistoric Complex Society: A Regional Perspective from the Valley of Mexico," JFA 1, 1974, pp. 81-108, in the Valley of Mexico.

${ }^{10}$ W. A. McDonald and G. R. Rapp, Jr., edd., The Minnesota Messenia Expedition, Minneapolis 1972.

${ }^{11}$ Renfrew and Wagstaff (footnote 7 above).

${ }^{12}$ J. F. Cherry, "A Preliminary Definition of Site Distribution on Melos," in Renfrew and Wagstaff (footnote 7 above), pp. 10-23.

${ }^{13}$ E.g., T. H. Van Andel and C. N. Runnels, Beyond the Acropolis: A Rural Greek Past, Stanford 1987; T. H. Van Andel and S. B. Sutton, Excavations at Franchthi Cave, Fascicule 2, Landscape and People of the Franchthi Region, T. W. Jacobsen, ed., Bloomington 1987 (southern Argolid); D. A. Davidson and C. Tasker, "Geomorphological Evolution during the Late Holocene," in Renfrew and Wagstaff (footnote 7 above), pp. 82-94 (Melos); D. A. Davidson, "Geomorphological Studies," in C. Renfrew, M. Gimbutas, and E. S. Elster, Excavations at Sitagroi (Monumenta Archaeologica 13), Los Angeles 1986, pp. 25-40 (the Drama Plain); J. L. Bintliff and A. M. Snodgrass, "The Cambridge/Bradford Boeotian Expedition: The First Four Years," JFA 12, 1985, pp. 123-161 (Boiotia).

${ }^{14}$ In order to be consistent in the use of place names, we use the term Nemea Valley to refer to the valley of the village of Ancient Nemea (Heraklion) and Phliasian Valley to refer to the valley of modern Nea Nemea. 
northeast Peloponnesos. Such an orientation would allow us to describe and compare the changing nature and extent of settlement and land use in the area at many stages of the past. A particular interest was to discover when settlement in the region probably had functioned autonomously and when it had been incorporated within larger social systems. It was further hoped that recognizing recurring patterns in the archaeological record would allow the construction of general models that might shed light on the dynamics of Peloponnesian society in periods of the past as yet poorly understood, both prehistoric and historic, by documenting the archaeological consequences of different types of political and economic organizations in those periods for which historical documentation is relatively ample.

A four-pronged research strategy was adopted by the project. A surface survey would record evidence useful for the reconstruction of past settlement and land use within the designated study area. Concurrent geomorphological investigations would focus on the formation of Holocene land forms and, especially, on the effects of human exploitation on cycles of erosion, deposition, and soil formation. An anthropological study would document patterns of settlement and land use since the Greek Revolution and would concentrate on the local consequences of incorporation of the Nemea area into the modern nation-state of Greece and into the world economy of which Greece is now a part. Finally, re-investigation of the prehistoric settlement on the hill of Tsoungiza at the head of the Nemea Valley, apparently the major prehistoric settlement in the area, would provide, together with the results of the recent excavations of the Sanctuary of Zeus, ${ }^{15}$ a detailed sequence of local types of artifacts, spanning most periods since the Neolithic. Excavation of Tsoungiza would permit a more complete reconstruction of the prehistoric settlement system in the Nemea area by uncovering a substantial part of what was apparently its largest settlement. The extent of interaction between the major prehistoric site and external areas could be evaluated independently and conclusions compared to those from the survey. For example, patterns of population growth or decline and trends toward greater or lesser socio-economic complexity at Tsoungiza could be compared with the picture reconstructed from surface finds alone.

Lofty goals of this sort demand clearly structured procedures for the documentation of data, especially to register precisely the location of surface and sub-surface artifacts. At Nemea computerized data storage and handling systems have regularized recording methods and facilitated the efficient retrieval of data, both in and out of the field. ${ }^{16}$ In the museum, specialized personnel examined artifacts and organic remains soon after their discovery. Such on-the-spot feedback fueled a constant interchange among members of the project that not infrequently influenced the course of subsequent fieldwork. ${ }^{17}$

${ }^{15}$ S. G. Miller, "Excavations at Nemea, 1984-1986," Hesperia 57, 1988, pp. 1-20, with references to earlier work.

${ }^{16}$ M. K. Dabney, "The Computerized Archives of the Nemea Valley Archaeological Project," AJA 92, 1988, pp. 249-250 (abstract). The formation of this aspect of the project has largely been the work of Dr. Mary Dabney, who has been responsible for museum studies and record systems. She coordinated the writing of recording formats for object analysis. Professor Robert F. Sutton, Jr. developed in concert with Cherry and Davis the computer files for the survey.

${ }^{17}$ Day-to-day processing of finds in the museum was overseen by Mary Dabney, assisted by Aileen 
The report that follows is based on active fieldwork and study of finds in the museum at Nemea between 1984 and 1989. Although preliminary, it is intended to present a fairly comprehensive view of over-all trends in settlement and land use in the Nemea area and to integrate results of studies conducted by all four arms of the project. For several periods of the past, political and economic relationships between the area and more extensive regional systems, both in the northeast Peloponnesos and beyond, are considered in light of available archaeological, historical, and ethnohistorical data. In conclusion, the analysis of these interactions suggests explanations for the changing fortunes both of the Nemea region and of the larger areas that affect it and provides a good illustration of the value of regionally oriented archaeological studies.

\section{THE ENVIRONMENTAL SETTING}

\section{Geographical Factors}

The Nemea Valley is one of a number of basins in the northeast Peloponnesos which are flanked to the southeast by the massif of Psyli Rachi, which divides the Corinthia from the Argolid, and to the west by the Kyllini range (Mt. Zeria), which borders Arkadia (Figs. 1 and 2). Immediately to the east is the Longopotamos Valley, containing the polis of Kleonai and the prehistoric settlement of Zygouries, while to the west the upper reaches of the Asopos river forms the extensive plain of Phliasia, in which lies ancient Phlius and a number of other prehistoric and later sites. ${ }^{18}$ Further west is the basin of Lake Stymphalos and the plain of Pheneos, upland regions with which Nemea has had very close connections, at least in recent centuries (see pp. 596-599 below). Access northward along any of these river courses to the Corinthian Gulf is generally steep and difficult, so that the role of passes through the hills and mountains has exerted an important influence on the patterns of settlement in the valleys, which command historically documented routes, particularly into the Argolid. From the Phliasian Plain, for instance, the anciently named Kelossa Pass leads southeast to the upper end of the Argive plain (Xenophon, Hellenica 4.7.7), and a steeper route crosses the hills at the west to ancient Stymphalos, whence originates the Roman aqueduct that runs through the area on its way to Corinth. ${ }^{19}$ Skirting the Nemea Valley to the southeast is the major route of communication in this area today, the Tretos Pass, now followed by the National Highway and by the railroad from Corinth to Argos. Two other routes lead from it to the Argolid, one above modern Agios Vasilios (and prehistoric

\footnotetext{
Ajootian (1985) and Wendy Thomas (1986-1987); Professor Jeremy Rutter supervised the study of prehistoric finds for both excavation and survey. Taylor Dabney was project photographer; Julia Pfaff supervised the drawing of artifacts, assisted by Julie Perlmutter (1985), Lyla Pinch (1986-1987), and Rosemary Robertson (1987). Finds were conserved by Tamsen Fuller (1984), Helen Alten (1984-1985), Alexandra Trone (1985-1987), and John Maseman (1986).

${ }^{18}$ For studies of ancient topographical accounts of this area, see Russell; G. Roux, Pausanias en Corinthie, Paris 1958; M. Sakellariou and N. Faraklas, Ancient Greek Cities, III, Corinthia-Cleonaea, Athens 1971; Faraklas; Pritchett, pp. 96-111; Wiseman, pp. 110-111; K. Adshead, Politics of the Archaic Peloponnese: The Transition from Archaic to Classical Politics, Aldershot 1986, pp. 1-18.

${ }^{19}$ Pausanias, 2.3.5; W. R. Biers, "Water from Stymphalos?" Hesperia 47, 1978, pp. 171-184.
} 


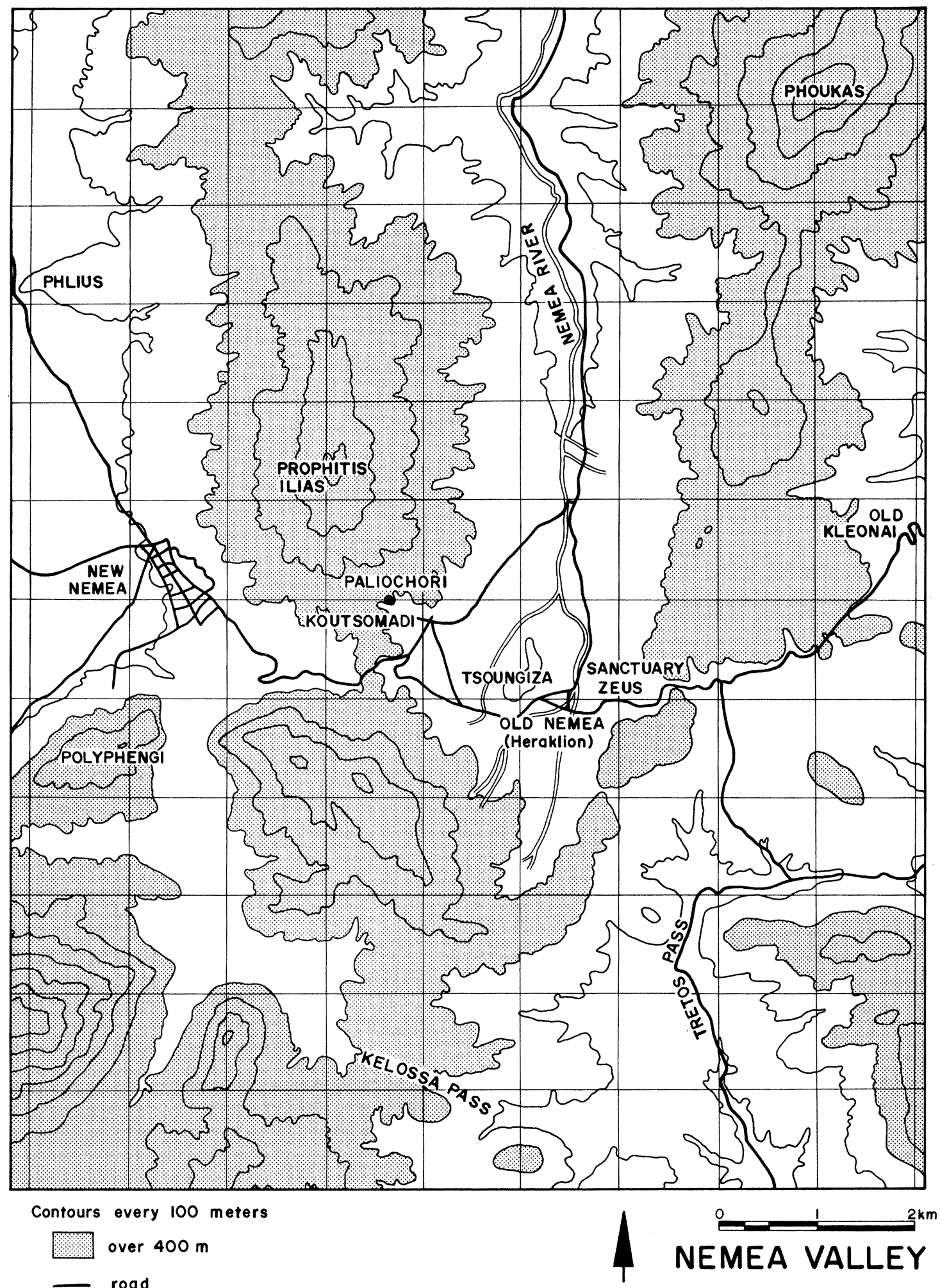

FIg. 2. Topographic map of the Nemea region (Julia E. Pfaff) 
Zygouries) to Mycenae, the other over Dervenakia. A yet more easterly road runs through Agion Oron, near modern Chiliomodi (ancient Tenea), down to modern Prosymna. ${ }^{20}$

The Nemea Valley is smaller than its neighbors, and although it lies near these passes, it is not linked directly to them. Rather, it is separated from them by a series of high hills (crossed by low passes) that ring the valley in a horseshoe shape at its southern end; these hills rise northward to Mt. Phoukas (ancient Mt. Apesas) on the east, and to Mt. Prophitis Ilias (ancient Mt. Trikaranon) on the west (Fig. 2, Pl. 93:a). Topographic factors thus serve to give strong definition to the valley proper, while at the same time making possible communication and interaction with regions both immediately adjacent and farther afield (as the existing historical and archaeological information already seemed to indicate). NVAP was formed to take advantage of this unusual geographical circumstance. Such a wellbounded landscape offered the chance of isolating forces acting on it, and its known history of settlement seemed to permit an integrated and detailed study of long-term variations in human occupation in a clearly defined region.

\section{Geological and Geomorphological Studies}

The investigation of the history of Late Quaternary alluviation in the NVAP study area is a first step towards understanding the impact man has made on the ancient Nemean landscape and the effects such alterations have had on his use of it. ${ }^{21}$ Most of the Nemea Valley and all the adjacent Xerokampos Valley have now been examined; study of the upland area between the Nemea Valley and the Tretos Pass remains to be undertaken. Principles of soil stratigraphy have guided our research. Since soils record hiatuses in deposition as they develop on stable landscape surfaces, which can be exposed to weathering for intervals of hundreds or thousands of years, it is possible to "fingerprint" each soil and then map its distribution throughout a landscape. ${ }^{22}$ If, as is often the case, a soil either buries or incorporates chronologically diagnostic cultural material within it, these artifacts can be used for dating. Ultimately it is possible to form a picture of which parts of the present surface of the landscape existed at particular times in the past. Results so far indicate that at least three times since the Early Neolithic period the hill slopes around the main valley became unstable and shed alluvium into a drainage network which was unable to transport all of it, and the result was aggradation on the valley floor. For some time during the Early or Middle Holocene, drainage in the valley was sluggish, and the valley floor may have been flooded for much, or even all, of the year. These events must (and can) be more closely dated, but it is already clear that the landscape of Nemea has been periodically unstable and that the environment has changed considerably since humans first settled there.

\footnotetext{
${ }^{20}$ Pausanias (2.15.2) describes the Tretos and Agios Sostis passes; Xenophon (Agesilaos 2.17) probably refers to the pass through Agion Oron; see Wiseman, pp. 121-125; L. E. Lord, "Watchtowers and Fortresses in Argolis," AJA 43, 1939, pp. 80-83.

${ }^{21}$ This section of the report is the work of Dr. Anne Demitrack. Tina Niemi served as general field assistant, and Sriyan Pietersz, Nicholas Ceh, and Elliott Lax helped with augering in the summer of 1986.

${ }^{22}$ P. W. Birkeland, Soils and Geomorphology, New York 1984.
} 
The slopes of the Nemea and Xerokampos valleys consist almost exclusively of Pliocene marl, with associated sandy marl, sandstone, and loose pebbly conglomerate. The marl is soft and easily eroded after it has been cleared of vegetation and is thus capable of supplying abundant alluvium to the valleys. A resistant, well-cemented Pliocene conglomerate (forming broad peaks and table platforms) caps the marl association. In the southernmost part of the study area, marly terrain gives way to older Pelagic limestones (upper Cretaceous) and a minor component of shale-chert-silicified limestones (Jurassic) which, even over a small area, vary spectacularly in color from green to purple. Valley bottoms are filled with Quaternary alluvium and are well watered by springs forming where the easily infiltrated, cemented conglomerate meets the more watertight marl. Drainage follows a regional fracture system northward to the Corinthian Gulf. ${ }^{23}$ A superficial network channels water from the main valley via a single stream (the Nemea River) which flows for more than $13 \mathrm{~km}$. in a narrow marl canyon. If it is blocked, drainage is impeded.

We have identified four soil-stratigraphic units, between Late Pleistocene and Late Holocene, in the Nemea Valley and five in the adjacent Xerokampos Valley (Fig. 3 and Table 1). ${ }^{24}$ The late Pleistocene was mainly a period of fan building (unit Pl). At least three successive fan alluvia were deposited, each followed by a long interval of non-deposition during which a soil formed on the exposed fan surfaces. The oldest alluvium in unit Pl developed a calcic soil with prominent $10-\mathrm{cm}$. nodules; in contrast, the succeeding alluvia are non-calcic. Climate and the contribution of air-borne calcareous dust govern the presence or absence of calcium carbonate in a soil; a slight change in either of these variables could have created the calcic-noncalcic soil sequence. ${ }^{25}$

During the Holocene (especially in the more recent past), fan building has been less important than stream deposition and colluviation for filling in the valley. At least three phases of stream deposits, separated by long intervals of no deposition and soil formation, occur in the early, late, and latest Holocene $\left(\mathrm{H}_{1}, \mathrm{H}_{2}\right.$, and $\mathrm{H}_{3}$ sets). The $\mathrm{H}_{1}$ unit contains Early Neolithic pottery, and it is clear that it began to be deposited at some stage after that period. The precise end of $\mathrm{H}_{1}$ deposition is as yet not fixed, but in the Xerokampos Valley an Early Bronze Age site (Site 512) sits on the $\mathrm{H}_{1}$ surface. After the $\mathrm{H}_{1}$ phase ended, there was a period without any deposition, when the streams cut into the valley floor and into the Pleistocene fan surfaces. There followed a period of no deposition which lasted into the Late Holocene, when the $\mathrm{H}_{2}$ phase appeared. Again, archaeological evidence suggests approximately when it was laid down: at the Sanctuary of Zeus, an earlier $\mathrm{H}_{2}$ phase buried the surface of the Classical Greek landscape and later buried Byzantine walls. Deposition in the latest Holocene $\left(\mathrm{H}_{3}\right.$ set $)$ is not voluminous, although the modern practice of bulldozing terraces out of the soft marl slopes and cultivating them without building terrace walls has already caused thin but widespread colluviation downslope. Modern streams in the valley are deeply incised.

${ }^{23}$ British Naval Intelligence Division, Handbook to Greece III, London 1945.

${ }^{24}$ The Quaternary stratigraphy of the Xerokampos Valley fits the model for the Nemea Valley, with minor modifications as noted in Table 1.

${ }^{25}$ L. H. Gile, F. F. Peterson, and R. B. Grossman, "Morphological and Genetic Sequence of Carbonate Accumulation in Desert Soils," Soil Science 101, 1966, pp. 347-360. 


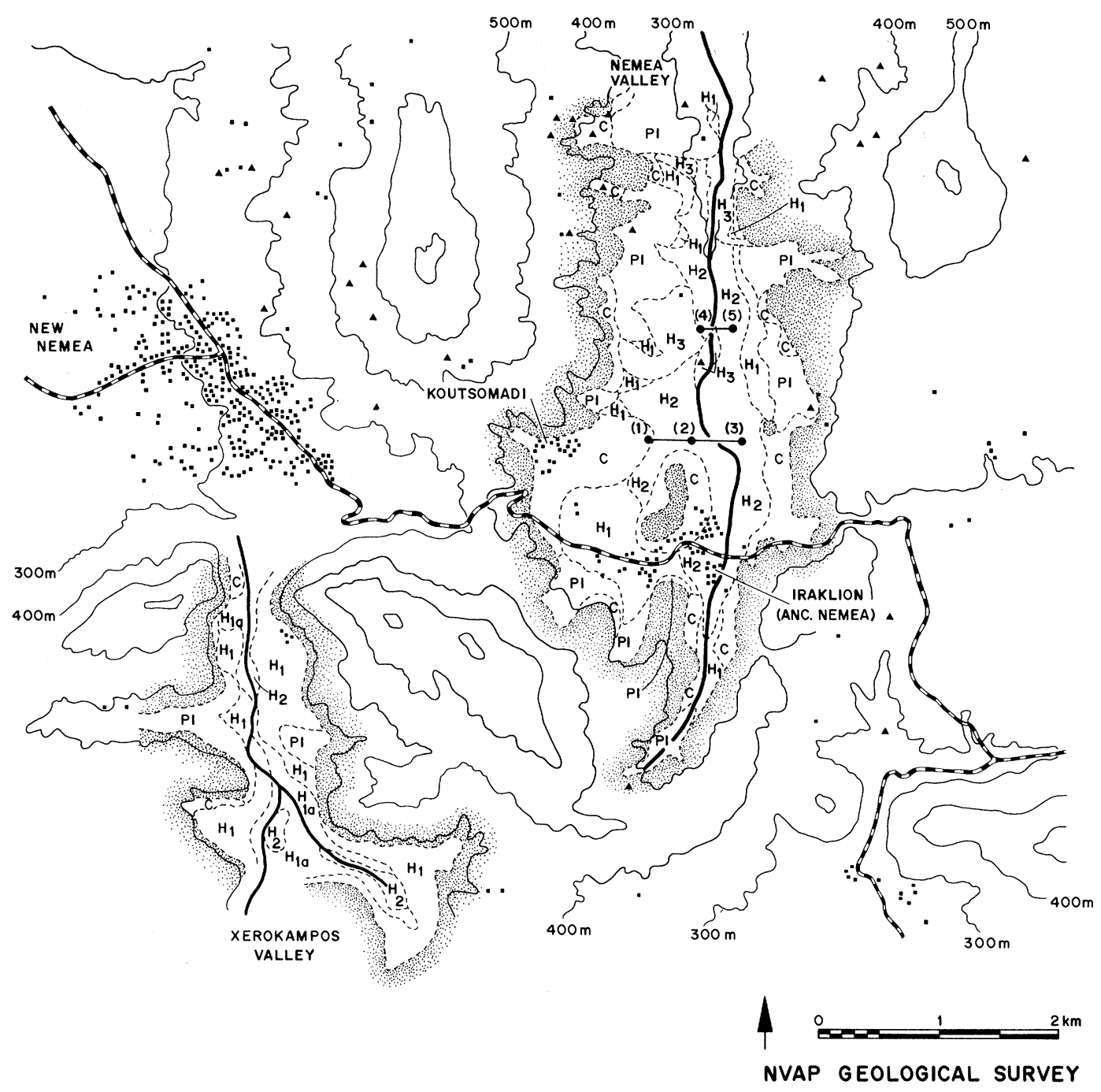

HOLOCENE

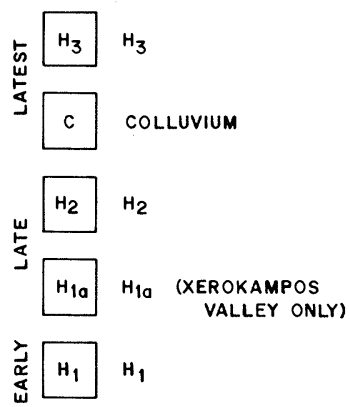

PLEISTOCENE

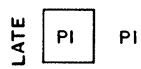

PLIOCENE OR OLDER

MARL, CONGLOMERATE, LIMESTONE, ETC.

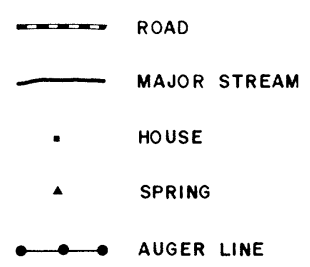

FIG. 3. The Quaternary geology of the NVAP study region (Anne Demitrack and Julia E. Pfaff) 


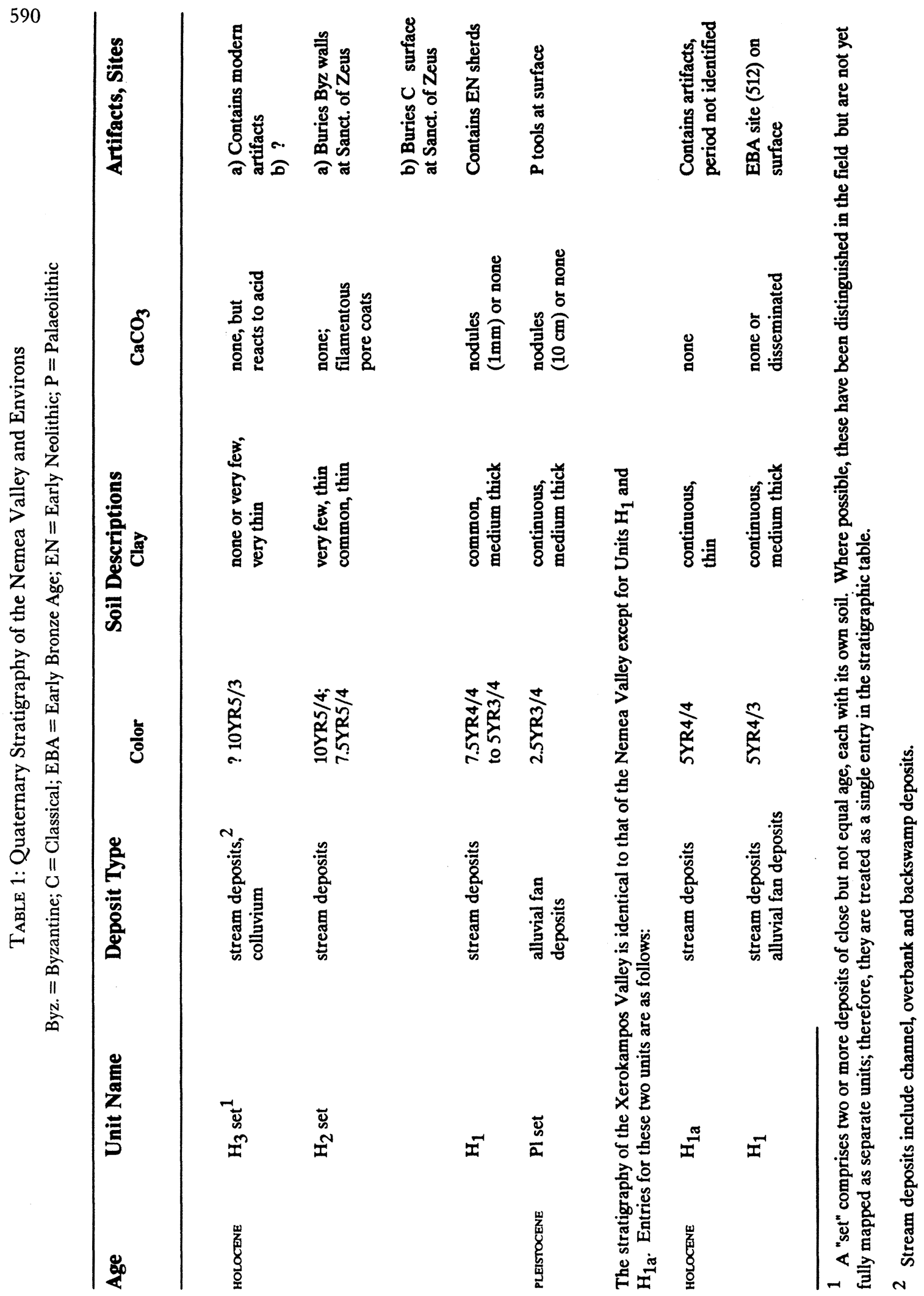


Sluggish drainage created seasonal or perhaps year-round swampy conditions sometime in the Early or Middle Holocene. Five auger cores in two east-west, cross-valley transects all show the same pattern. An upper 75-150 cm. of well-drained, brown silt loam (with $\mathrm{H}_{2}$ soil development) grades downward into $175-500 \mathrm{~cm}$. of predominantly silty clay or clay. $\mathrm{H}_{2}$ soil development on the brown silt loam indicates that it has been exposed to weathering for some time and, together with the absence of mottling in the deposit, suggests that the (stream) flooding which deposited the loam was not sustained for any long period. In contrast, the very fine texture, gley coloring, and poor or nonexistent soil development on the underlying silty clay/clay in three of the five cores points to seasonal or longer term swamp conditions. In the other two cores, a buried $\mathrm{H}_{1}$ soil at the stratigraphic level of the silty clay/clay shows that in post-Neolithic times some parts of that horizon had been exposed to surface weathering. Thus, while there has been a long-term evolution towards the better-drained conditions seen today, the distribution of micro-environments on the valley floor has shifted over time in a complex pattern. The role of man in these changes, in both recent and prehistoric times, remains to be determined.

\section{Historical Egology and Palynology}

During the 1985 field season, an investigation of aspects of the modern and ancient vegetation of the Nemea region was undertaken. ${ }^{26}$ There were two main goals: 1 ) to locate and core several sites likely to produce ancient pollen; 2) to study the modern vegetation with a view to understanding the historical ecology of the wider region within which the NVAP study area lies. Almost fifty locations were visited in the Nemea, Phliasian and Kleonai valleys, together with their surrounding mountain slopes, as well as places farther afield in the north-central Argolid and in the Arkadian-Lakonian-Argolic corner.

Nemea lies close to the dividing line between the wetter, western and drier, eastern sides of Greece, a division corresponding roughly to areas with more or less than $600 \mathrm{~mm}$. annual rainfall. ${ }^{27}$ As in other parts of Greece, the regime of vegetation in the valley appears to be determined mainly by moisture (i.e., not only by rainfall but also by the water-retaining properties of soils and rocks). The mosaic of maquis, garigue, and steppe vegetation on hard limestone (e.g. Mt. Daouli) is replaced by lusher, more nearly continuous maquis on soft limestone and marl, but massive, unfissured rocks (e.g. the conglomerate of Mt. Polyphengi) have only garigue and steppe, with little maquis. The hills around Nemea are well vegetated with dense but patchy maquis of Quercus coccifera (prickly oak) and other trees in the form of shrubs. Among indicators of relatively high rainfall, Arbutus unedo (strawberry tree) is locally abundant, but Arbutus andrachne (andrachne) is somewhat rare, and Quercus ilex (holm oak) is to be found no nearer than the eastern Argolid. The vegetation

${ }^{26}$ By Dr. Oliver Rackham (University of Cambridge), Dr. Margaret Atherden (College of Ripon and York), Dr. Jennifer Moody (University of Minnesota), and Elliott Lax. The present account, a select summary drawn from a report submitted by this team, is the work of Atherden, Moody, and Rackham.

${ }^{27}$ Nemea is also close to another frontier, namely the southwesterly limit of the Pinus halepensis (Aleppo pine) woods of the Isthmus and northern Peloponnesos. Here, as in Boiotia, their distribution is poorly understood, not being obviously linked either to rainfall or particular soil types. 
changes abruptly as one moves southeastward from Nemea: Mycenae, only $10 \mathrm{~km}$. distant over the hills, is much more arid. The sibljak (deciduous maquis) of Lakonia, and the lowland deciduous woods of Lakonia and western Crete, are poorly represented here. There are no mountain pines, and the nearest montane vegetation is to be found in the firwoods and the remains of deciduous woods on Mts. Pharmakas and Oligyros and in the basin of Lake Stymphalos, some $25 \mathrm{~km}$. to the west.

Well over half the Nemea region is now under cultivation, which, most unusually for Greece (see pp. 594-603 below), is more extensive now than a century ago. Very little remains of the fens in the plains, and even Lake Stymphalos has been much reduced by drainage. The modern wild vegetation is limited partly by the availability of moisture and partly by browsing of ovi-caprids and burning. ${ }^{28}$ Woodland is now increasing, at least in the upland regions, through the growth into trees of Quercus coccifera and other maquis shrubs. This is in part a result of the decline in sheepherding, which has reduced browsing that has in the past maintained the wood as shrubs. The decline in the sheep and goat population, however, is not yet great, and woodland is increasing no more rapidly than in Boiotia and much less quickly than in Lakonia. ${ }^{29}$ In general the cliffs around Nemea are not remarkable botanically (as they are in Lakonia and Crete) as refugia of trees sensitive to browsing. There is also a southwestward advance of Pinus halepensis (Aleppo pine) and, on a small scale, a downward advance of the mountain firs.

Although the history of vegetation must await analysis of our pollen samples and the detailed study of historical sources, it is apparent that the structure of the present landscape is very dependent on human activities. Except for the spread of cultivation, it appears not to have changed much in the last 2000 years. To judge from the little that contemporary authors tell us, the landscape of the northeast Peloponnesos in Classical times was already much closer to the present balance of land uses than to the original wildwood. Woodland was already rare; sacred groves were often not the natural woods but plantations of cypress (the traces of one of which have been excavated in the Sanctuary of Zeus at Nemea). ${ }^{30}$ Another surviving detail of the Classical landscape is the wild celery, which plays a part in

\footnotetext{
${ }^{28}$ Burning is on the increase, largely because the maquis becomes more combustible as it gets taller; it has been possible to study the effects of several fires that have occurred in the study region since 1983. Maquis appears to be more combustible and to recover more easily from a fire than garigue; all the evergreen trees and shrubs sprout from the base. Pinus halepensis is killed by fire, but fire stimulates germination of its seeds, and it seems that a pinewood could still be maintained even if it burned every 15 years. See O. Rackham, "Observations on the Historical Ecology of Boeotia," BSA 78, 1983, pp. 291-351, esp. pp. 325-326.

${ }^{29}$ Boeotia: Rackham, op. cit.; Lakonia: field studies by Rackham in 1984 (final report in preparation).

${ }^{30}$ Pausanias, 2.15.2; S. G. Miller, "Excavations at Nemea, 1976," Hesperia 46, 1977 (pp. 1-26), p. 11; idem, "Excavations at Nemea, 1977," Hesperia 47, 1978 (pp. 58-88), p. 65 and pl. 11 (the evidence for a sacred grove in the sanctuary is being published by Professor Darice Birge for the University of California at Berkeley project in the Sanctuary of Zeus). The team visited places where Pausanias mentions trees and woods. Among them is Skotitas (sacred to Zeus Skotitas), between Agios Petros and Arachova in the northern Parnon; it represents the oldest named wood lot known in Europe. It is a coppice wood chiefly of Quercus frainetto (deciduous oak), which appears to be the special oak of ancient woods in the Peloponnesos, and it has a rich flora full of relict species from a more northerly climate.
} 
TABLE 2: Radiocarbon Dates from the Kleonai Core

Sample No.

AA-2739

AA- 2740

AA-2741

AA-2742

AA-2743

AA-2744

AA-2745
Radiocarbon Age B.P.

$3345.0 \pm 70.0$

$3820.0 \pm 50.0$

$4770.0 \pm 70.0$

$6150.0 \pm 70.0$

$7495.0 \pm 60.0$

$7475.0 \pm 60.0$

$9030.0 \pm 100.0$
Calibrated Ages B.c. (Maximum Minimum)

1735 (1685 1673165716551638$) 1530$

$2429(229222462235) 2146$

$3643(361935763531) 3383$

$5227(52005170513951025082) 4949$

$6431(638763116311630762756267) 6187$

6423 (6379 63196248$) 6183$

Not Available

Nemean mythology and which was used to crown the victors in the Nemean games. The species, still growing by the local springs, is Apium nodiflorum, not certainly recorded elsewhere in Greece.

Erosion is a spectacular feature of the northeastern Peloponnesian landscape, although it is confined to marls and schists. It dates, at least in part, from after the Roman period, but the process is now dormant almost everywhere, unless reawakened by modern agriculture. Our observations suggest strongly that the lack of plant cover has not been responsible for erosion; tectonic movement is the most probable cause.

The study of palaeo-vegetation has been approached by means of prospection for sites likely to produce ancient pollen. After much searching, three sites were selected for vibrocoring: 1) in the Nemea Valley itself, about $1 \mathrm{~km}$. north of the Sanctuary of Zeus; 2) southeast of the village of Kephalari, at the foot of Mt. Kyllini; and 3) in the Kleonai Valley, between Kondostavlos and Chania. All three cores were sampled at $5-\mathrm{cm}$. intervals for pollen, shell, and soil, but so little pollen was preserved in the cores from the first two locations that their analysis was abandoned as unproductive. The Kleonai core, however, is $329 \mathrm{~cm}$. long and preserves at least 19 stratigraphic units, defined on the basis of color and soil texture, some of which contain significant organic matter, including satisfactory quantities of palaeo-pollen and micro-mollusca. ${ }^{31}$ It is already clear that the vegetational story of the region accords generally with that seen at other sites in southern Greece, although radiocarbon dates (Table 2) suggest an earlier appearance of some indicators of human presence than previously thought. ${ }^{32}$ For example, the presence at a depth of $172 \mathrm{~cm}$. of pollen of Castanea (sweet chestnut), a tree thought to have been introduced by man from $c a$. 3500-3200 B.P. onwards, is here dated to $c a .8380-8136$ B.P. (at one standard deviation). ${ }^{33}$

${ }^{31}$ The mollusca have been analyzed by Dr. Hartwig Schütt. All species from the core are known from present-day freshwater contexts in Greece, and no evidence has been recognized that suggests any alteration in the climate (personal communication, 27 March 1989).

${ }^{32}$ H. E. Wright, Jr., "Vegetation History," in McDonald and Rapp (footnote 10 above), pp. 188-199.

${ }^{33}$ Contra W. Van Zeist and S. Bottema, "Vegetational History of the Eastern Mediterranean and the Near East during the Last 20,000 Years," in Palaeoclimates, Palaeoenvironments, and Human Communities in the Eastern Mediterranean Region in Later Prehistory (BAR International Series 133), J. L. Bintliff and W. Van Zeist, edd., Oxford 1982, pp. 277-321, esp. p. 287. 


\section{ANTHROPOLOGICAL STUDIES}

The project has supported a detailed anthropological study of the valley's contemporary condition, a study which has explored not only those aspects of past technology still practiced in the present but also those features of modern life which have few antecedents. ${ }^{34}$ As a way of fulfilling the project's general goals the anthropological component has aimed at producing a systemic, regional understanding of contemporary settlement and land use.

\section{Methods and Approaches for Understanding the Modern Period}

This research strategy, which compares the full round of modern life to various periods of the past, sees more in the present than simply the occasional remains of practices also found in antiquity. A sizable body of research on modern Greece now exists, ${ }^{35}$ yet the full power of this corpus has seldom been used in the study of the Greek past. Indeed, anthropological work often has been used to identify technological practices that are believed not to have changed from antiquity to the present. In this process, other aspects of contemporary life are disčarded as not comparable to the past. Such endeavors, however well intentioned, both underutilize the ethnoarchaeological information available and reflect a misunderstanding of the historical context of contemporary Greek life. They reflect an implicit assumption that current Greek villages are carriers of an unbroken agricultural tradition only recently transformed by the processes of industrialization, urbanization, and tourism. This assumption is only heightened by the tendency of most village studies to emphasize the deleterious effects of recent out-migration, thus giving the misleading impression that these settlements have long been stable.

This sense of untouched and timeless rural Greek life exists, however, in the face of considerable evidence to the contrary. There is every indication that Mediaeval and modern Greek villages were shaped by the same forces of change as ancient ones. The rural Greek

${ }^{34}$ This section of the report is the work of Susan B. Sutton. In this study I have been helped by six excellent research assistants. William Alexander threw himself into all aspects of this research with skill, good humor, and a remarkable ability to converse with villagers about their lives; Anastasia Karakasidou undertook the delicate task of eliciting local political opinions; Mary Stender, Janine Beckley, Marytheresa Fagan, and Will O'Daix diligently turned our scraps and pieces of notes into usable computer files. Archaeological survey teams also painstakingly recorded tract-by-tract data on modern land use.

Several families, including those of Theodosios and Vasiliki Zavitsas, Katina Papadopoulos, Panayiotis and Panagoula Schoinochoritis, Ritsa Pitterou, Photis Chiotis, and Vasilis Zaimis, were constant sources of advice and information. Officials of near-by villages, the National Statistical Service, and the Corinthian Agricultural Ministry were similarly forthcoming with public records.

${ }^{35}$ Anthropological and sociological studies of modern Greece might best be sampled by beginning with classic works such as J. Campbell, Honour, Family and Patronage, Oxford 1964; E. Friedl, Vasilika, New York 1962; I. Lambiri, Social Change in a Greek Country Town, Athens 1965; and I. T. Sanders, Rainbow in the Rock, Cambridge 1962 and then moving on to more recent studies such as M. Herzfeld, The Poetics of Manhood, Princeton 1985; Regional Variation in Modern Greece and Cyprus (Annals of the New York Academy of Sciences 268), M. Dimen and E. Friedl, edd., New York 1976; and Gender and Power in Rural Greece, J. Dubisch, ed., Princeton 1986. Important geographical studies are J. Baxevanis, Economy and Population Movements in the Peloponnesos of Greece (National Centre of Social Research), Athens 1972; B. Kayser, P.-Y. Péchoux, and M. Sivignon, Exode rural et attraction urbaine en Grèce, Athens 1971; Kolodny; and

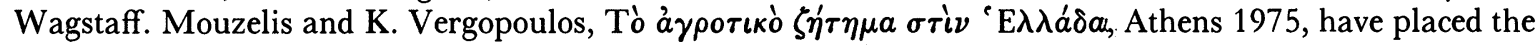
study of the Greek political economy on an equal footing with these other concerns. 
population has quite literally been in motion for centuries. ${ }^{36}$ The well-known Slavic and Albanian migrations of the Middle Ages provide but one example. The disproportionate growth of mountain villages in the 17th century, followed by the reappearance and development of lowland ones in the 19th, provides yet another. Indeed, even the most seemingly isolated villages today have long been affected by the marketization of the Greek economy and the transformation from an imperial system to a nation-state that occurred on the heels of the Greek Revolution. To assert that contemporary villages are only just now becoming aware of, or involved in, the forces of change is to follow a very selective application of historical principles.

If Greek villages have indeed been in a state of flux for many centuries, what is one to make then of the points of similarity which sometimes seem to exist between these settlements and those of antiquity? The simple answer would be to say that some aspects of life have survived intact throughout time while others have changed. This may sometimes be true, but a more complex, and probably more accurate, answer allows for traits to appear, disappear, and then reappear, depending on the circumstances in which a particular region finds itself at various points in history. The periodicity of settlement, a unifying theme of NVAP, is consistent with such assumptions. Times of population concentration in the Nemea Valley may be discovered to have something in common with each other such that even when they occur at widely separated dates no direct continuity need be documented. Conversely, a particular agricultural practice may have continued throughout times of both population growth and decline but has taken on a very different meaning in each of these contexts.

The ethnoarchaeological study of the Greek present must, therefore, be more than a search for artifactual relics and residual cultural practices. ${ }^{37}$ A complete study of the contemporary situation can reveal both the interpretive context of isolated traits and the causal factors behind current settlement and economic strategies. Such insights, in turn, indicate which periods of the past most resemble the present and are thus most suitable for drawing parallels. When such complete analyses are undertaken for all periods within a particular region, enough factors may be held constant to reveal the forces behind both recurrent and unique patterns of settlement and economy in that region.

Our attempt to gain a systemic understanding of modern settlement has been guided by particular attention to the transformation from the imperial, largely feudal system of the Ottoman Empire to a centralized nation-state greatly involved in international, capitalized networks. ${ }^{38}$ Understanding how the Nemea Valley fared in this process has required several

${ }^{36}$ For a more detailed discussion of such historical migration patterns, see H. Antoniades-Bibicou, "Villages désertes en Grèce: un bilan provisoire," in Villages désertes et histoire economique, XIe-XVIII e siècles (École Pratique des Hautes Études), Paris 1965, pp. 343-417; Kolodny; McGrew; V. Panayiotopoulos,

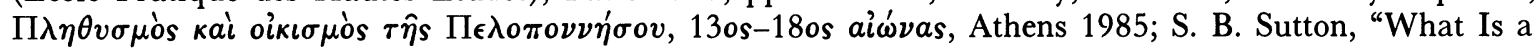
'Village' in a Nation of Migrants?" Journal of Modern Greek Studies 6, 1988, pp. 187-215; Wagstaff.

${ }^{37}$ One might, therefore, take issue with the position recently espoused by Jacobsen ([footnote 8 above] pp. 92-93).

${ }^{38}$ While some may feel that not all modern Greek villages have participated in this process, Mouzelis (passim) has convincingly argued that Greece's subordinate position in international networks has produced a disarticulated economy in which labor-intensive, familial economic strategies exist alongside industrialized 
lines of inquiry. Some of this work has involved the identification of changing agricultural and housing patterns by dating existing structures and settlements, compiling agricultural production statistics from official records, collecting data on current agricultural land use from the tract records of the archaeological survey, comparing a series of aerial and hilltop photographs of the valley taken over the last 60 years, and undertaking discussions and historical research concerning land tenure, village formation, and changing agricultural strategies. This information has been placed even more firmly in its human context through intensive interviews with a representative sample of valley residents, together with a detailed genealogical analysis of local population records. Observations and discussions of relationships with other settlements have also been made. The preliminary results of this research have identified the Nemea Valley as an area of demographic growth during the modern period, and indeed one that illustrates well the processes of village formation and the development of an agricultural system oriented toward export.

\section{Modern Settlement Growth in the Nemea Valley}

The last two centuries of Ottoman rule in Greece witnessed a gradual depopulation of lowland areas in favor of mountainous ones. ${ }^{39}$ The feudal systems of the Ottoman Empire increasingly came to supply raw materials and foodstuffs to the economically expansive nations of western Europe. ${ }^{40}$ As this happened, Turkish landowners extracted larger and larger payments from the Greek peasants working on their estates. Many peasants subsequently fled the plains, where Turkish rule was more firmly established, and sought refuge in the mountains. While exact dating of such movement for the Nemea area must await further analysis, it is already clear that the area did lose population sometime prior to the modern period. Survey data (Fig. 11) suggest the Nemea Valley was well populated and farmed in Byzantine times, but both travelers' accounts and oral history indicate that it was very sparsely inhabited just prior to the Greek Revolution. A few Stymphalian and Arkadian shepherds wintered their flocks there, and a small village of some twenty families was perched on Prophitis Ilias, the western hill bounding the valley. ${ }^{41}$ This village, then known

ones. Both types are nevertheless part of the same system, and the products and migrant labor produced by villages with low levels of mechanization find their way into the markets and workplaces of Athens. To view these less mechanized villages as unconnected to the rest of the modern Greek economy is to misunderstand how that economy works. Thus to extract the occasional use of older agricultural techniques from this context and treat them as indicating only a locally oriented economy is dubious at best.

${ }^{39}$ McGrew; Panayiotopoulos (footnote 36 above).

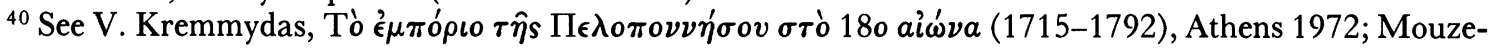
lis, pp. 5-8.

${ }^{41}$ Descriptions of the Nemea Valley at this time may be found in E. D. Clarke, Travels in Various Countries of Europe, Asia and Africa, London 1814, p. 714 and F. C. H. L. Pouqueville, Voyage de la Grèce, Paris 1826, V, p. 182. The latter quotes population figures from the Turkish cadastre in use in the early 19th century. According to oral history there was also a second small village, Groutsi, located on the eastern flank of Prophitis Ilias, toward the extreme northern end of the valley. Since this region lies outside the study area, it was not included in this analysis. Its history is somewhat parallel to that of Koutsoumadi, since no village is located there today, and most of its former inhabitants are said to have moved either to the villages in the Phliasian Plain or to Chalki. 
as Koutsoumadi but today abandoned and referred to as Palaiochori (directly above Koutsoumadi in Figure 2), ${ }^{42}$ pursued a mixed economy of grain farming, wine making, and sheepherding. Only the remains of the temple of Zeus, scattered shepherds' shelters, and the village's wine-making structures were on the valley floor, which was often flooded and marshy in the spring and summer.

While research began with the assumption that the modern Nemea Valley was always part of a settlement system oriented toward the Corinth-Argos road, such ideas were soon overturned. Mounting evidence has shown that the old village of Koutsoumadi looked not eastward but westward toward the town of Agios Georgios (now Nea Nemea) in the Phliasian Plain. Agios Georgios, a settlement of 600 inhabitants in 1800, was closely aligned with the near-by monastery of the Panagia tou Vrachou Nemeas (on Mt. Polyphengi: Fig. 2; Fig. 4, site 900), both of which had strong seasonal relationships with the shepherd communities of the mountains even further west. Together, they served as an agricultural, marketing, and political center for a settlement system bordered by Lake Stymphalos and Pheneos on the west and the old village of Koutsoumadi on the east (Fig. 1). This settlement system was connected, in turn, to the much larger market town of Argos, not by the Tretos Pass but rather by a road exiting the southwestern corner of the Phliasian Plain (the Kelossa Pass of Classical antiquity).

Older residents of the Nemea Valley still recall that late into the 19th century their families transported wine and other produce to Argos via this road, often using the services of merchants from Agios Georgios. They also confirm that the place of origin of the shepherds who used the valley for winter pasturage was the mountains near Lake Stymphalos and beyond.

The Nemea Valley thus began the modern period as a thinly inhabited side pocket of a regional system centering around the Phliasian Plain and extending westward into the mountains. Agricultural production for sale was at fairly low levels throughout this system, the valley was little farmed, much of the land was given over to pasturage, and its only village was located as close to the Phliasian Plain as possible. The scant Turkish remains found in the Nemea Valley indicate that it may also have served as a buffer zone between the strongly controlled Turkish farming estates found closer to Corinth and the more independent upland areas to the west.

The forces set in motion by the Greek Revolution soon transformed such settlement patterns. With the expulsion of the Ottomans, small family farms came to predominate over feudal forms of land tenure in Greece, ${ }^{43}$ while local political systems began to look toward the centralized national government in Athens. ${ }^{44}$ Additionally, the direct involvement of

${ }^{42}$ The change of place names in this region can be confusing. The old village of Koutsoumadi, now abandoned, is called Palaiochori. The new village of Linoi eventually took on the name Koutsoumadi. It and the new village of Heraklion form the koinotes now officially called Archaia Nemea but hardly ever referred to as that by the local residents. Agios Georgios is now officially Nea Nemea, and referred to by everyone, including residents of Archaia Nemea, simply as Nemea.

${ }^{43}$ Mouzelis, pp. 11-16; McGrew.

${ }^{44} \mathrm{~J}$. A. Petropoulos, Politics and Statecraft in the Kingdom of Greece, 1833-1843, Princeton 1968. 


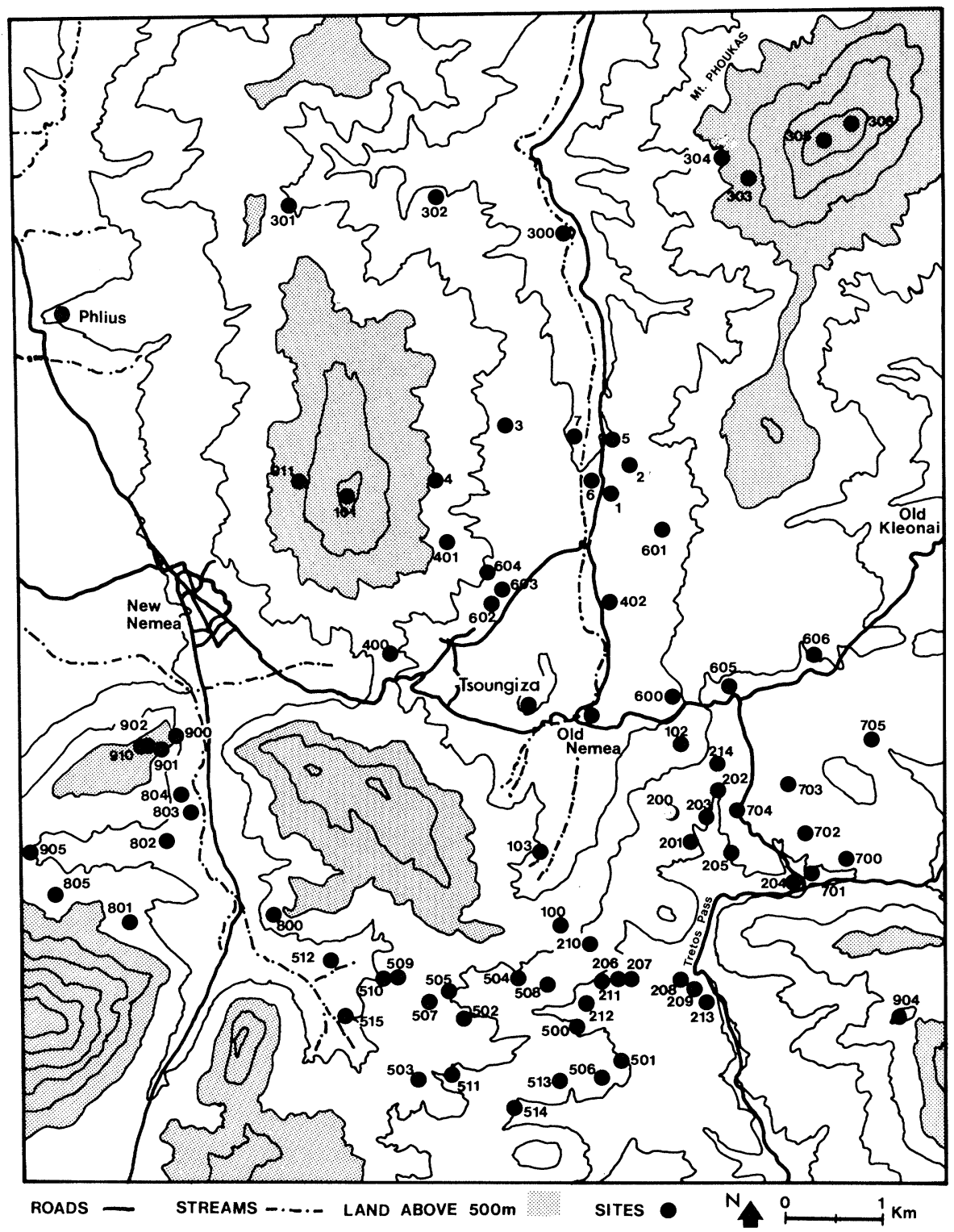

FIg. 4. Map showing the distribution of sites recorded by the NVAP survey (John Cherry)

other European nations in the establishment of the new state created strong relationships between Greece and these nations. Such forces resulted in a series of migrations that largely reversed the demographic trends of the previous three centuries, and generally brought rural Greeks into more direct contact with the national and international systems now surrounding them. ${ }^{45}$ The refuge afforded by geographical isolation was considered less necessary with the

${ }^{45}$ McGrew (passim) describes the migrations; Vergopoulos ([footnote 35 above] pp. 101-162) discusses the increasing involvement of the countryside in commercialized agriculture. 
TABLE 3: Demographic Growth of Nemea Valley and Phliasian Plain during the Modern Period

$\begin{array}{ccc}\text { Date } & \text { Nemea Valley } & \text { Town of Agios Georgios (New Nemea) } \\ 1800 & 100 & 600 \\ 1851 & 140 & 960 \\ 1870 & 216 & 1517 \\ 1920 & 618 & 2620 \\ 1981 & 748 & 4182\end{array}$

The figures for 1800 are drawn from Pouqueville (footnote 41 above), p. 182. Those for 1851 come from

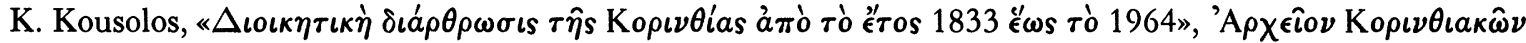

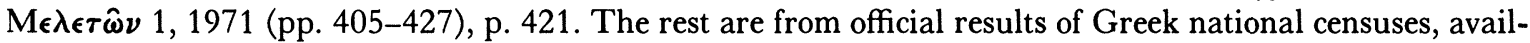
able at the National Statistical Service in Athens.

departure of the Turks. Rural Greeks began leaving the mountains and once again settling the plains and coasts to take advantage of the new opportunities which were appearing.

Both the Nemea Valley and Phliasian Plain benefited from these events. All evidence shows the expansion of population, settlement, and agricultural vitality for these areas virtually up to the present. The availability of open and unclaimed land situated relatively close to the increasingly important centers of Argos and Corinth provided opportunities not matched in many other areas of the Peloponnesos. As shown in Table 3, the population of both the Nemea Valley and the town of Agios Georgios has increased. These growth rates far exceed those of national rates of natural increase and reflect the in-migration of peasants from other areas. The first waves of these migrants appeared shortly after the Greek Revolution. Family histories, the demotologio (municipal census), and the local list of men maintained for the military draft indicate that most newcomers to the Nemea Valley were from the mountains near Lake Stymphalos and further south into Arkadia, while a few others were attracted from parts of Central Greece. At least some, if not most, of the former already had some connection to the area, either through kinship or previous use of the area as winter pasturage. Some of the migrants attached themselves to the existing village of Koutsoumadi, which dominated the farm lands of the valley, while others created a series of isolated familial compounds scattered at the valley's perimeter and beyond.

The Koutsoumadiote families expanded their agricultural operations by staking out fields and vineyards in the valley bottom. The valley was part of the National Lands which became available for purchase at very low rates from the Greek government during the 19th century. Koutsoumadiotes trekked up and down the hillside to these newly opened lands, turning many into vineyards for either currants or wine grapes. ${ }^{46}$ The fact that the soil of both the Nemea Valley and the Phliasian Plain was considered particularly suitable for vineyards was especially important as currants became the principal Greek export crop of the 19th century. Peloponnesian currant cultivation had slowly increased during the 18th

\footnotetext{
${ }^{46}$ All grapes and currants are variations of one single species, vitis vinifera. Currant grapes, known in the Peloponnesos as mavri (black) or korinthiaki staphida (Corinthian raisin grape) differ from most other variations primarily by their small size and dark color; they are dried before processing or consumption.
} 
century, as these small, dark, dried grapes found their way into the increasingly sweet diets of northern Europe and North America ${ }^{47}$ Production levels grew at an even faster pace in the 19th century as the English taste for dried currants reached its peak, and French vintners began using a re-liquefied dried currant base for their wines after French vineyards suffered a devastating blight in 1877. This general expansion of Koutsoumadiote vineyards also involved some production of must from both currants and other grapes, sold locally and also exported as a basis for wine and other alcoholic beverages.

So successful was this entrance into market-oriented agriculture that when an earthquake leveled Koutsoumadi in $1876,{ }^{48}$ its inhabitants, rather than reconstructing the old village, moved to the new lands they had opened up either in the Phliasian Plain or the Nemea Valley. In this process, the stone foundations of the ruined mud-brick houses were carried down the hill, which at least partially accounts for the very scanty remains that now mark where old Koutsoumadi once stood. Two loose clusters of houses thus appeared on the Nemea Valley floor, one just at the base of Prophitis Ilias and called Linoi (later changed to the name of the old village, Koutsoumadi; Fig. 2), and the other at the small hill of Tzoungiza and called Heraklion. Histories concerning familial land holdings indicate that each of these two settlements was formed primarily by families who owned land in that particular area.

The scattered familial compounds which had simultaneously been arising in near-by areas outside the valley were not so directly involved in viticulture as Linoi and Heraklion. Interviews with descendants of these families indicate that some compounds were former winter shelters of shepherd families which were gradually converted into more permanent residences as these families became more attached to the area. A milling operation formed the nucleus of another hamlet at Chani Anesti in the Tretos Pass, and the new compound of a sheepherding family which moved to the area on a year-round basis from central Greece became known as Papoutseïka.

By the end of the 19th century this proliferation of settlements began coalescing toward the two major clusters of houses in the Nemea Valley. Elderly villagers now recall the stories of their parents and grandparents concerning this period. Both Linoi and Heraklion were developing a sense of community. There was a general belief among their residents that much was to be gained if these settlements were to take on the characteristics of proper villages. Government recognition and services, marketing opportunities, and the quality of social life would all be enhanced. It also appears that intermarriage among family lines led to the families of subsequent generations each holding land in various locations around the valley, which reinforced the utility of a settlement centrally located in the midst of these fields. Thus, churches were established in each village, some families donated land for communal squares (plateies) and other facilities, and small groceries (pantopoleia) appeared.

${ }^{47}$ S. Mintz, Sweetness and Power, New York 1985. The British Diplomatic and Consular Reports on Trade and Finances (District of Patras) from the Peloponnesos, which present a yearly accounting of the ups and downs of the 19th-century currant trade from 1871 to 1914 (Foreign Office, London 1871-1914), indicate that few currants were grown under the Ottomans until the 17th century, when production of dried currants for English markets slowly increased.

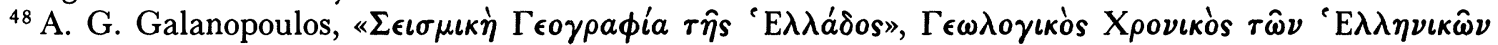
$\mathrm{X} \omega \rho \hat{\omega} \nu$ 6, 1955 (pp. 83-121), p. 93. 
As this process continued, the two villages became the focus of most new in-migration to the area, and many surrounding hamlets were abandoned when their inhabitants decided to move to the new centers. Buildings became more densely packed within the two settlements as new houses for married children were built in the open spaces surrounding the original houses. Conversely, the buildings of the former outlying compounds were either converted from houses to sheepfolds or left to ruin.

A change in transportation networks also worked to the benefit of the Nemea Valley. While in the 18th century the roadways of greatest importance to the Nemea Valley had been to the Phliasian Plain and from there down to Argos or up to the mountains, other routes supplanted these in the 19th century. The road along the Tretos Pass between Argos and Corinth became the major land route for communications between much of the Peloponnesos and the growing center of Athens. People from the Phliasian Plain and further west thus began traversing the Nemea Valley as the most direct link to this new thoroughfare. Traffic through the valley increased even more when the Athens-Argos-Nauplion railroad was completed in 1890. This valley, which had once been a side pocket of the Phliasian Plain, thus became an artery in that area's communication with the outside. Heraklion, situated more firmly on the connecting road than Linoi, outpaced the other village in population growth. Its original plateia, somewhat north of the main road, was eventually abandoned as the village assumed an increasingly linear pattern along the main road through the valley.

Because the Corinthia in general and the Nemea area in particular produced currants of the highest quality, these areas were able to withstand the economic crisis which hit many Peloponnesian farmers at the end of the 19th century. When French vineyards were regenerated around 1890, and that nation placed a virtual ban on the importation of the very Greek currants which they had once so eagerly welcomed, many currant growers throughout the Peloponnesos found themselves impoverished almost overnight. Major waves of rural Greek migration both to Athens and the United States resulted. The Nemea area, however, was able to command what remained of the currant market and continues as one of the largest producers of dried currants in Greece to this day. The declining demand for dried currants, however, was also met with some diversification of the market crops grown in the valley. There has since been a steady increase in the number of vineyards converted to other types of wine grapes, especially after a Phylloxera blight destroyed many of the valley's currants in the 1950's. Nemean wine (from both the Nemea Valley and Phliasian Plain) is widely marketed throughout Greece. More recently, extensive olive orchards have been planted, sometimes replacing vineyards, as a more reliable and less labor-intensive cash crop than vines. Almost all the valley and its slopes have thus been progressively opened up for cultivation, a situation which appears clearly in a comparison of aerial photographs for different dates during the 20th century. At the same time, subsistence crops for local use, such as grains, have virtually disappeared. The area has become fully integrated into an external, market economy, a process intensified by seasonal employment created by the foreign archaeological work done in the area in recent years. 


\section{Discussion}

Far from being untouched repositories of ancient custom, the contemporary villages of the Nemea Valley thus owe their very existence to the new systems set in motion by the creation of the modern Greek state. As noted earlier, however, this fact does not remove these villages from comparison with the valley's earlier development. Indeed, it identifies exactly what about the present is most relevant for understanding the past, and vice versa. The modern period has been a time of settlement foundation, population growth, and increased cultivation for the Nemea Valley. The valley has experienced similar patterns of growth, followed by decline, only to be followed by growth once again throughout its history (see pp. 616-617, 638 below). Both the past and the present can inform each other on this matter.

Certainly this study of the present reveals much concerning the creation of settlements in the area. How is it that a phase with very few settlements could be followed very suddenly by one with many settlements, a phenomenon not limited to modern times? This is actually exactly what has been observed for the modern period, when the single settlement of old Koutsoumadi was followed in short order by the installation of many vineyards and the construction of familial compounds. At least for modern times, such a proliferation of settlement has indicated a time of familial mobility and the opening up of new opportunities.

The eventual coalescence of these many small settlements into fewer but larger villages is also illuminating. The functions of centralized villages that the villagers themselves perceive and the role of intermarriage and land inheritance in reinforcing this perception may well find parallels in ancient periods. The growth of the valley's main settlement at a geographical location which has been its center at several other times indicates something about that specific location. Modern Heraklion encompasses and surrounds Tsoungiza, a position which rises above the sometimes swampy areas, yet is centrally located when the valley floor is under cultivation, and is found on both the main east-west and north-south communication routes of the valley.

In modern times the Phliasian Plain emerges as an almost constant demographic and economic center, while settlement in the Nemea Valley has been more ephemeral. The Phliasian Plain is equally fertile and well watered but is also much larger and slightly higher than Nemea, a condition which makes it suitable for a wider variety of crops, as shown today by the production figures for both areas. Not only is it a natural agricultural center but it is also a major point of connection between mountainous areas and the similarly long-lived center of Argos. The Nemea Valley, on the other hand, lacks such characteristics. Its fortunes are clearly a reflection of the larger system around it and can best be understood in this context. In this light, a comprehensive study of the modern Nemea Valley advances the general understanding of Greek history by demonstrating how marginal areas develop in response to these other centers and what they contribute to the growth or decline of the better-known settlements.

The general idea that Greek agriculturalists have been on the move as much as they have been settled now seems beyond doubt. The study of the modern period underscores what this means for the standard terms used to describe settlement. Villages, houses, family 
lines, in short the most fundamental institutions of Greek rural life, are shown to have a flexibility which defies rigid definition. Over time, a building can change from a seasonal shelter to a permanent one to a stable and in the end be completely abandoned. ${ }^{49}$ Familial composition, geographical affiliation, and land holdings are similarly not so fixed as idealized statements concerning patrida (fatherland) and oikogeneia (family) sometimes indicate. The lesson to be learned, of course, is to modify these terms to account for the elements of time, change, and adaptive modifications, especially for a population as mobile as has been that of rural Greece.

\section{ARCHAEOLOGICAL STUDIES}

\section{The Arghaeological Survey}

\section{Goals and Scope}

Specific problems addressed by the archaeological survey, in addition to the general goals cited at the outset (p. 584 above), fall into three distinct categories: 1) establishing the distribution of artifacts of particular dates within the survey area; 2 ) evaluating how far such distributions adequately represent past patterns of settlement and other human activities; 3) providing some explanation for long-term changes in the human behavior which such patterns reflect. These issues clearly require careful consideration of geomorphological processes which in some cases may have been responsible for the dispersion and redeposition of artifacts. The survey takes as its most basic unit of analysis not the site but rather the individual artifact: we are interested in accounting for the existence of all traces of human activity on the landscape and not merely major concentrations of artifacts or those which still remain in their original place of deposition..$^{50}$

Given the emphasis of earlier work in the Nemea region on its central places, or on other sites of special architectural interest (such as towers or the segment of a Roman aqueduct on the slopes of Mt. Strongylo, below Polyphengi; Fig. 2), ${ }^{51}$ our chief focus has been on the nature and distribution of less prominent remains of all periods, but other more specific

${ }^{49}$ This is a cycle of use carefully documented by T. M. Whitelaw in "The Ethnoarchaeology of Recent Rural Settlement and Land Use in Northwest Keos," chapter 21 in Cherry et al., Archaeological Landscape.

${ }^{50}$ This section of the report is the work of John F. Cherry, Jack L. Davis, and Eleni Mantzourani. Our method of survey is in many ways similar to that of so-called "non-site" surveys: cf. D. H. Thomas, "Non-site Sampling in Archaeology: Up the Creek without a Site?" in Sampling in Archaeology, J. W. Mueller, ed., Tucson 1975, pp. 61-81; R. Foley, "Off-site Archaeology: An Approach for the Short-sited," in Pattern of the Past: Studies in Honour of David Clarke, I. Hodder, G. L. Isaac, and N. Hammond, edd., Cambridge 1981, pp. 157-183; R. C. Dunnell and W. S. Dancey, "The Siteless Survey: A Regional Scale Data Collection Strategy," Advances in Archaeological Method and Theory VI, M. B. Schiffer, ed., New York 1983, pp. 267-287; and S. J. Shennan, Experiments in the Collection and Analysis of Archaeological Survey Data: The East Hampshire Survey, Sheffield 1985.

${ }^{51}$ E.g., Russell; Sakellariou and Faraklas (footnote 18 above); Faraklas; Biers, 1969; Biers, 1971; W. R. Biers, "Excavations at Phlius, 1970," Hesperia 40, 1971, pp. 424-447; idem, "Excavations at Phlius, 1972," Hesperia 42, 1973, pp. 102-120; idem, "The Theater at Phlius: Excavations of 1973," Hesperia 44, 1975, pp. 51-68; Biers (footnote 19 above); Miller, 1975; Miller, 1976; S. G. Miller, "Excavations at Nemea, 1976," Hesperia 46, 1977, pp. 1-26; Miller, 1977 and 1978 (footnote 30 above); S. G. Miller, "Excavations at Nemea, 1978," Hesperia 48, 1979, pp. 73-103; Miller, 1980; Miller, 1982; Miller (footnote 15 above). 
questions may also be noted. For the Neolithic and Bronze Ages, basic issues are whether there ever existed in the valley a recognizable hierarchy of sites and what role Tsoungiza played in any such settlement system. Later, in Classical antiquity, one might have expected the area around Nemea to be organized as a city-state, like the near-by territories of Kleonai, Phlius, and Sikyon; in fact, the historical sources show that it was politically weak and that the panhellenic sanctuary was controlled for much of its life by external powers. The extent to which this situation was the product of general depopulation in the Greek Dark Age and in early historical times or was forced upon the Nemeans through the intervention of external states is a question of considerable interest and one to which only archaeology at a regional scale can contribute fresh information. As regards Byzantine, Frankish, and Ottoman times, there is so little archaeological evidence for patterns of rural settlement and land use in southern Greece that any new fieldwork could be expected to produce useful additional knowledge.

The total area of $c a .80$ sq. $\mathrm{km}$. available to the project extends south from Mt. Phoukas and the ridge of ancient Phlius to the Dervenakia (Tretos) Pass and Mt. Strongylo (south of Polyphengi on Figure 2; see also Figure 4 and Plate 93:a). In three years of fieldwork, ca. 50 sq.km. of this total has been examined, much of it in a contiguous block around the site of Tsoungiza and the Sanctuary of Zeus but also including substantial samples of the more northerly reaches of the upper Nemea Valley and of the valleys immediately to the south; of the west slope of Mt. Prophitis Ilias, east and southeast of Phlius; and of the slopes overlooking the Longopotamos Valley, southwest of ancient Kleonai. The zones examined each season were selected to provide a good cross section of the variety of landscape types and locational settings, and the cumulative results of each campaign have guided the selection of areas (chosen on the basis of landscape, vegetation, and soil types) to be examined in subsequent years.

\section{Methods}

The essential feature of our method of survey is the examination of many individual "tracts", which are natural or arbitrary areas of relatively uniform vegetation, land use, and visibility, no more than one or two hectares in size. ${ }^{52}$ These are surveyed by teams of 5 to 7 members walking across them at $c a$. 15-m. intervals in parallel transects. Each member uses a handheld counter to record quantities of pottery, tile, and other materials for each $100-\mathrm{m}$. segment of his one or more "passes" across the tract. Collections are made of all potentially diagnostic pottery (i.e., all but plain body sherds), all chipped stone, and any other types of materials. Tracts are described in terms of their present-day land use, soil type, vegetation cover, and the extent to which the ground surface is visible at the time of survey. The end result is a computer-generated archive of mosaiclike maps, which now cover some 4,800 surveyed tracts and which show the over-all density and distribution of artifacts of various

\footnotetext{
${ }^{52}$ Individual finds are numbered sequentially within sectors, a grid of numbered one- $\mathrm{km}$. squares covering the entire survey area, which in turn has been split into five topographically distinct areas; thus each tract has a unique Area-Sector-Tract designation.
} 


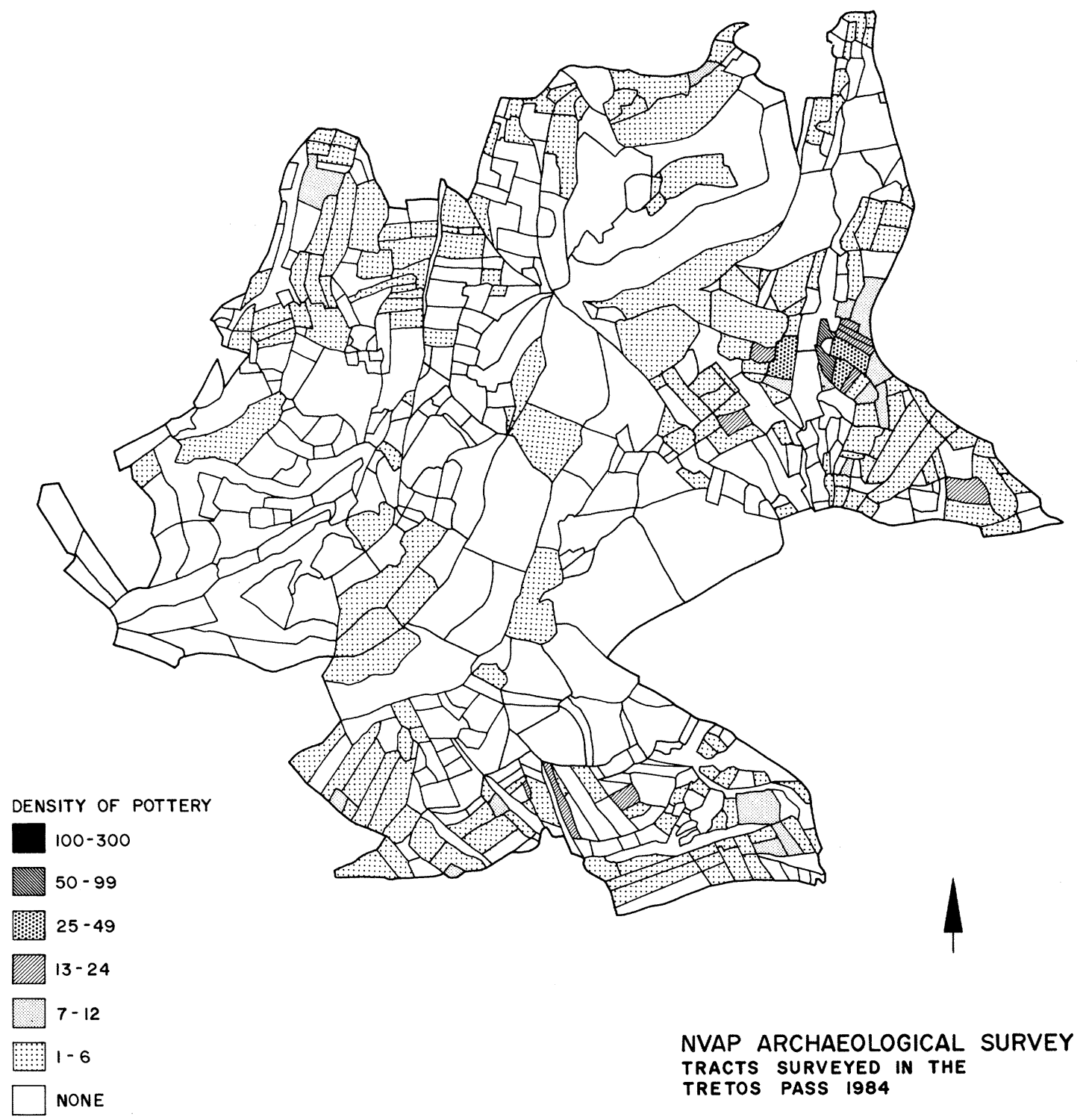

FIG. 5. Tracts surveyed in the area north of the Tretos Pass, 1984, showing the overall density of pottery (Joan Pederson and Julia E. Pfaff)

kinds and dates over the entire area surveyed (e.g., Figs. 5 and 6). From these it is possible, for instance, to evaluate the effect of relative surface-visibility conditions on the observed spatial patterns of artifacts of different periods. The collection of information on vegetation, visibility, and artifact density, as well as details of the artifacts themselves, produces a volume of data that would be unmanageable without the use of computers for storage and 


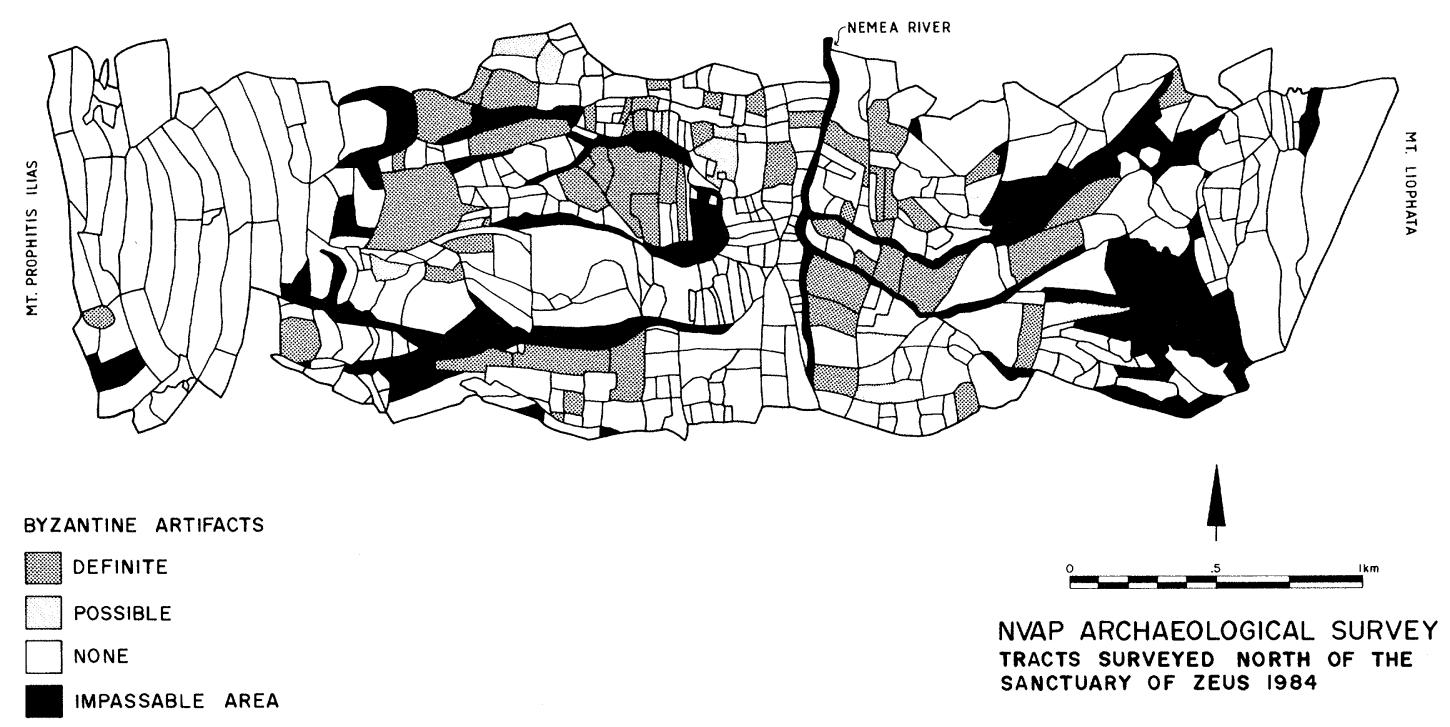

Fig. 6. Tracts surveyed in a 1-km. wide transect across the Nemea Valley located $2 \mathrm{~km}$. north of the Sanctuary of Zeus, 1984, showing the density of Byzantine pottery (Joan Pederson and Julia E. Pfaff)

processing; even the basic file recording each walker's artifact counts is well over 20,000 lines in length and contains information on 23 variables. ${ }^{53}$

Sites are surprisingly difficult to define objectively in any survey. We consider them to be anomalously dense concentrations of artifacts with definable spatial limits. Once recognized using these criteria, they are investigated further, generally by the collection of additional samples of artifacts. Standard procedure involves the collection of all artifacts found within circles 5 sq.m. in area, located at 5- or 10-m. intervals along each of four orthogonal transects laid over the site, after which "grab" samples of potentially diagnostic artifacts are collected from each of the four quadrants defined by the transects. In many cases, however, it has been preferable to lay down a $10-$ or $20-\mathrm{m}$. grid (or even at times one of smaller frame) to allow greater spatial control over the collection and plotting of material (Fig. 7). Thus, it is possible to gain not only a quantified estimate of the over-all size of the site but also a good understanding of its extent and nature during each of the periods when it was in use. Work at such places normally includes documentation by means of photographs, sketch maps, and

${ }^{53}$ Information gathered daily by teams in the field was entered on an Epson Geneva PX-8 lap-computer and later transferred to the Project's Kaypro IV personal computer in the Nemea Museum (a portable Zenith with a $20 \mathrm{mb}$. hard disk is now used). Densities of artifacts for each tract could thus be calculated readily and mapped immediately, so that the locations of potential sites could be singled out for re-examination in the field the next day. The dating, counting, and weighing of artifacts collected from tracts rapidly provide information on the distribution of finds of particular dates and on the dating of material from high-density concentrations (many of which are later treated as "sites"). Eventually, information from both the field and the museum is transferred to mainframe computers, where it can be analyzed more readily and where computer-generated maps can be produced. 


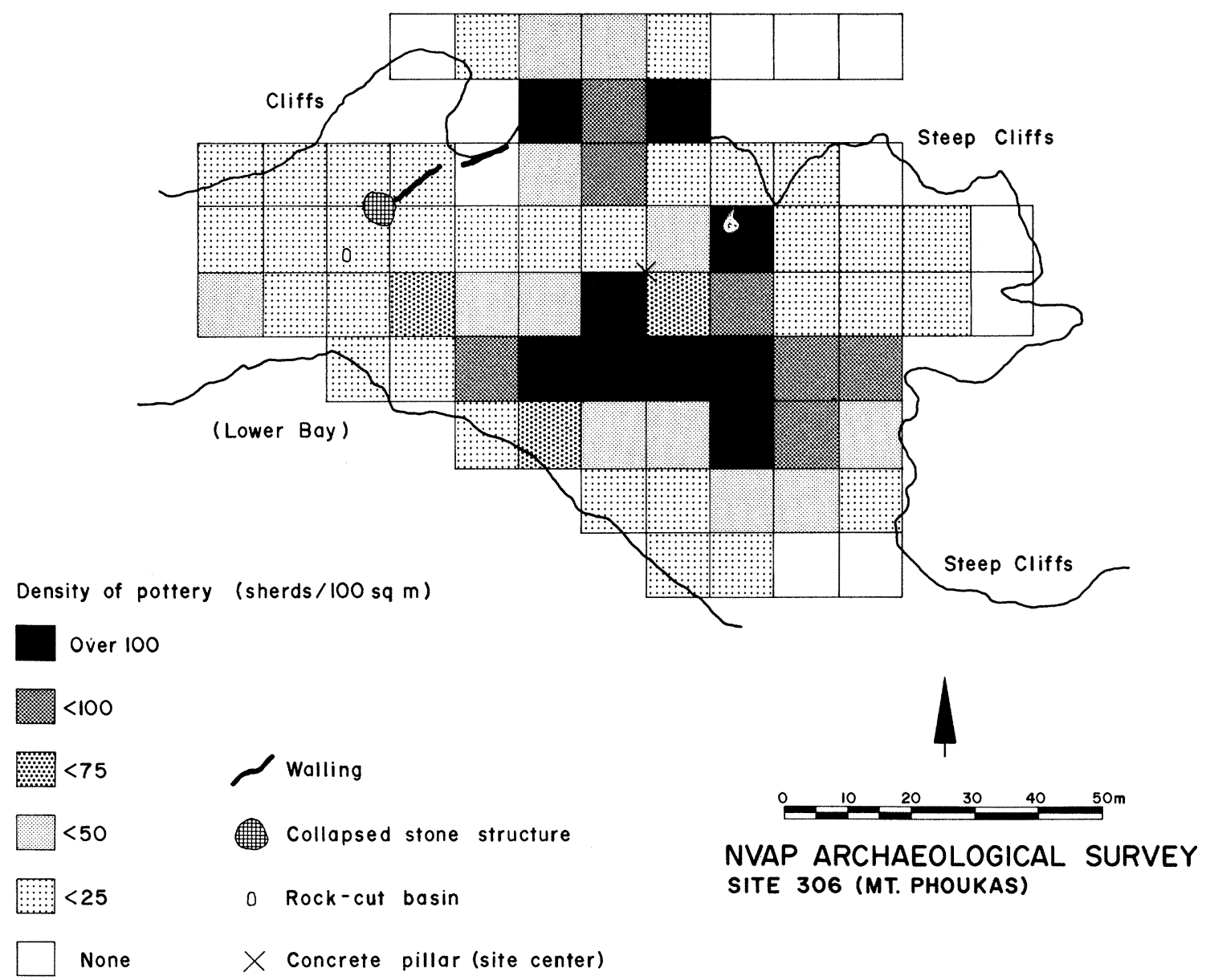

FIG. 7. The ash altar of Zeus atop ancient Mt. Apesas, showing the survey grid and the density of pottery collected from the site (John Cherry and Julia E. Pfaff)

measured drawings; when feasible, further information about subsurface remains may be gathered, for instance by geophysical survey. ${ }^{54}$

It is obvious that various natural processes can lead to the dispersion of artifacts at the surface, affecting our perception of the scale and kind of activities conducted in the past at a particular location. Geomorphological investigation of disturbances at "sites" has thus become routine procedure on most archaeological surveys. The focus of our project on the individual artifact, however, forces us also to consider how far post-depositional geomorphological disturbances have contributed to the creation of lower-density artifact distributions of the sort which have been found to be nearly continuous in many parts of the survey area. Analytical procedures are needed to distinguish between those cases which represent

${ }^{54}$ For a more detailed illustration of the different phases of data collection in the field, see Cherry et al., 1988. 
short-term, comparatively ephemeral human activities in the past, and those in which artifacts have been redeposited from other locations through non-cultural means. ${ }^{55}$ An example may be useful.

On the northeast slope of the undulating ridge leading down from Evangelistria (just east of Heraklion) towards Chani Anesti (immediately north of the Tretos Pass; Fig. 2), Classical, Hellenistic, and Byzantine pottery was found in moderate quantities (tract 71-8). The tract lies downhill from site 200 (Fig. 4) just to the north, although Classical and Hellenistic remains were not found there; site 201 to the south and site 203 to the northeast both have Classical and Hellenistic artifacts but are separated from tract $71-8$ by a ravine. The likelihood is thus that the artifacts here are in situ. On the opposite side of the ravine to the northeast, in tract 71-2, Byzantine pottery was noted; in this case, however, the position of the tract downslope from site 203 (where pottery of this date was plentiful) makes it likely that the artifacts in this tract are not in their original place of deposition, and geomorphological considerations add weight to this conclusion. When this approach is extended to the entirety of the study area, we anticipate that patterns in the quantities, location, and date of artifacts, both in situ and in post-depositional contexts, may contribute to our understanding not only of changes in land use but also of the erosional history of the region.

\section{General Gharacter of the Survey Finds}

Material collected from the surveyed area $^{56}$ ranges in date from early prehistoric times through the 20th century after Christ. ${ }^{57}$ It may be noted in passing that as much as onethird of the total quantity derives from collections in tracts, thus providing some indication of how much useful information is lost if attention is restricted solely to material from "sites". Finds of ancient glass and metal (including coins) have been surprisingly sparse. The collection of chipped stone (mostly Melian obsidian and a variety of local cherts) is

${ }^{55}$ A preliminary approach to such studies using NVAP data may be found in J. Pederson, "Background Noise" in Pedestrian Archaeological Survey: A Geomorphological Evaluation in the Nemea Valley, Greece (M.A. thesis, Department of Geography, University of Illinois at Chicago 1986).

${ }^{56}$ Professor Robert F. Sutton, Jr. has been in over-all charge of the processing and initial study of survey finds in the Nemea Museum, assisted by Shari Stocker (1984), Professsor Lynn Kraynak (1984), Thomas Strasser (1985-1987), Effie Athanassopoulou (1985-1987), and by other members of the survey teams. A portion of the following discussion is extracted from notes provided by Sutton. Final reports on the following categories of survey finds are in preparation: Neolithic pottery (Strasser), Early Bronze Age pottery (Laurie Roberts), Later Bronze Age pottery (Cherry, Davis, and Mantzourani), Geometric through Roman pottery (R. Sutton), Mediaeval pottery (Athanassopoulou), and tile (Hugh Elton). Chipped and ground stone has been studied by Dr. Robin Torrence and Professor Curtis N. Runnels, respectively, and will be published by Cherry. We are particularly grateful to members of the NVAP team for their comments on prehistoric pottery and to the following who have examined material in Nemea or offered other help and advice: Professor Kathleen W. Slane, who served as a regular consultant on Roman pottery and local wares in general, Professor John E. Coleman, Margarete Hahn, Dr. John W. Hayes, Professor John C. Lavezzi, Catherine A. Morgan, Professor Catherine Perlès, Guy Sandars, Ulrike Steppcke, Professor Karen D. Vitelli, Dr. Berit Wells, and Dr. Charles K. Williams, II.

${ }^{57}$ At several localities, particularly near the headwaters of the Nemea River, there have been found heavily rolled and patinated lithic artifacts resting on the surface of Pleistocene alluvial fans (Table 1, Fig. 3); these are not easy to date either by their geomorphological context or by their typology but are very probably of Palaeolithic date. 
small and for the most part not readily datable; ground stone includes fragments of imported hand-querns and millstones of Classical to Mediaeval date, and a number of large olive presses of local conglomerate have been recorded in the field. Ancient standing architecture of any sort is not common. Thus the overwhelming majority of our chronological information on the distribution of ancient settlement and land use is based on pottery, tile, and other terracotta small finds, of which well in excess of 100,000 items have been recorded in the course of tract-walking. The state of preservation makes close chronological or functional identification difficult for much of this material, but assignment to broad periods (e.g., Archaic to Classical, or Late Roman to Byzantine) is usually possible. ${ }^{58} \mathrm{~A}$ brief selection of typical diagnostic survey finds is presented here as representative of the sort of material on which more general conclusions inevitably rest.

Prehistoric pottery from the survey in general closely parallels the excavated material from Tsoungiza in terms both of types and of principal chronological periods represented. A conspectus of the Neolithic material has already been presented elsewhere, ${ }^{59}$ it is noteworthy that, as at Tsoungiza, EN and MN pottery of standard northeast Peloponnesian types is well attested, while the LN and FN periods are scarcely represented at all. Similarly, the occurrence of EH I and (especially) EH II material, in substantial quantities and at many sites, stands in stark contrast to the rarity of EH III sherds and the virtual absence of recognizable $\mathrm{MH}$ types. ${ }^{60}$ Our ability to discriminate among different phases of Mycenaean pottery depends largely on the level of preservation of the individual sherds, but Early Mycenaean pottery (i.e., earlier than LH IIIA:2) is in general readily distinguished from that of later phases. ${ }^{61}$ Late Bronze Age finds, however, are notably sparse in an area so close to the Mycenaean heartland.

A major goal of the study of the pottery of the historic periods has been to differentiate strictly local products (i.e., those produced in the area surveyed or near-by centers such as Kleonai) from material imported from the dominant neighboring centers of the Corinthia and the Argolid, or from further afield (see Appendix, pp. 646-659 below). The discovery

${ }^{58}$ After washing (without acid), finds were transferred to the Nemea Museum. All non-pottery finds (including tile from sites and lamps) were immediately registered individually in a central database stored on the microcomputer. Ceramic finds from all samples collected from sites and tracts were weighed and counted, and the number of datable finds assignable to each period was recorded. Finally, detailed descriptions of all pottery and tile from tracts and of a selection of chronologically and functionally representative finds from sites were compiled: these will form the basis of catalogues of finds to be included in final publications.

${ }^{59}$ Cherry et al., 1988, where examples of MN and FN vessels are illustrated, together with a general discussion of Neolithic finds of all periods in the Nemea region.

${ }^{60}$ It may be noted that the abundance or scarcity of pottery of different periods does not correspond to their relative "visibility" as defined in J. B. Rutter, "Some Thoughts on the Analysis of Ceramic Data Generated by Site Surveys," in Archaeological Survey in the Mediterranean Area (BAR International Series 155), D. R. Keller and D. W. Rupp, edd., Oxford 1983, pp. 137-142. For instance, MH is one of Rutter's periods of "high visibility", yet we have recovered virtually no sherds of Minyan or Matt-painted wares.

${ }^{61}$ For a preliminary study of the EH finds from the survey, see L. Roberts, "Early Bronze Age Settlement in Southern Greece: New Data from the Nemea Valley," $A J A$ 92, 1988, p. 252 (abstract); Mycenaean material and its specific distribution in the survey area has been discussed by J. L. Davis, "'If There's Room at the Top, What's at the Bottom?" BICS 35, 1988, pp. 164-165 (abstract) and Wright et al., "Early Mycenaean Settlement." 
of two new kilns (at sites 510 and 512), at least one used for pottery, is particularly useful in this respect; they may be set alongside the two tile kilns previously excavated in the Sanctuary of Zeus. ${ }^{62}$ We plan a variety of scientific pottery analyses to enhance the results of more conventional study. Most of the pottery does, in fact, seem to have been made in the northeast Peloponnesos. Large quantities of imports from further afield occur only at Phlius and certain other very large sites. This isolated pattern provides a clear contrast to the record from those parts of the island of Keos and of the Southern Argolid which have recently been surveyed by comparable techniques and whose extensive coastlines provided direct access to maritime commerce. ${ }^{63}$ This dearth of imports is not restricted to fine wares that might be considered luxuries traded for their own sake, e.g., Attic black glaze (p. 649 below; Fig. 23), ${ }^{64}$ Roman sigillata or Red Slip (p. 655 below; Fig. 26), and Proto-Majolica wares, but also includes coarse-ware trade amphoras, of which only Corinthian A jars occur with any frequency (p. 653 below; Fig. 24). The rarity of amphoras is especially striking in comparison to the situation on Keos and suggests that, while the islanders made considerable use of imported foodstuffs carried in such containers, the region around Nemea was much more self-sufficient. ${ }^{65}$

\section{Site Types and Long-term Patterns of Settlement}

The most common types of site encountered are characterized by small scatters of Archaic, Classical, or Hellenistic finds, including tile, cooking and storage vessels, small quantities of fine ware, and (less often) quernstones or olive presses. Many of these are probably farmhouses or other rural agricultural installations of the kind that typify most sets of survey data in southern Greece. ${ }^{66}$ With the exception of Phlius, the Sanctuary of Zeus, and near-by sites such as Kleonai, there are few really large sites of these dates that obviously belong to another level of settlement hierarchy. Functionally specific sites of other kinds, however, are known: for instance, four isolated towers, built of large dressed limestone or conglomerate blocks, ${ }^{67}$ and several sites possibly to be considered as rural sanctuaries on the basis of the discovery of likely votive material. In Roman and Byzantine times the pattern of

${ }^{62}$ Cf. Biers, 1971, pp. 401-402 on the difficulties of distinguishing the fabric of Phlius from those of Corinth and Argos; he and others seem to apply the term "Argive" loosely to products from various centers in the Argive plain. For the kilns see B. H. Hill, The Temple of Zeus at Nemea (revised and supplemented by Charles K. Williams, II), Princeton 1964, p. 46; Miller, 1975, pp. 161-165; Miller, 1976, pp. 186-189.

${ }^{63}$ R. Sutton, chapter 11 in Cherry et al., Archaeological Landscape and R. Sutton in M. H. Munn, D. J. Pullen, and C. N. Runnels, Artifact and Assemblage: Finds from a Regional Survey of the Southern Argolid, Stanford (in preparation).

${ }^{64} \mathrm{~A}$ conspectus of finds from the survey is given in the Appendix.

${ }^{65}$ R. Sutton, in Cherry et al., Archaeological Landscape.

${ }^{66}$ E.g., chapter 17 in Cherry et al., Archaeological Landscape; Bintliff and Snodgrass (footnote 13 above); Van Andel and Runnels (footnote 13 above). By no means all such sites need have been residential: cf. R. Osborne, "Buildings and Residence on the Land in Classical and Hellenistic Greece: The Contribution of Epigraphy," BSA 80, 1985, pp. 119-128 and idem, Classical Landscape with Figures, London 1987.

${ }^{67}$ Sites $800,904,905$, and 911. All are square except 904, which is circular, and all probably served a military function, since they occupy strategic points on important routes. The associated pottery dates mainly to the Classical and Hellenistic eras. For references, see Faraklas, Appendix 2, nos. 2 and 3; Pritchett, p. 98 and pl. 67; Russell, pp. 41 and 44; Lord (footnote 20 above), pp. 80-85 and pl. iv:a; Wiseman, pp. 113-116 and figs. 157-159; E. Meyer, RE XX, 1, 1941, cols. 269-290, s.v. Phleious. 
residential settlement was evidently more differentiated, since in addition to small rural establishments there existed a number of much larger sites. Some idea of the range of sites other than small-scale rural settlements, and of the types of material to be found at them, may be conveyed by several brief examples.

1. Site 204 (Fig. 8) occupies a small bluff overlooking the National Highway as it runs through the Tretos Pass, a few hundred meters north of Chani Anesti (Fig. 4). Bulldozing and deep ploughing in 1984 brought to light over 2,000 well-preserved sherds of EH I and early (pre-sauceboat) EH II date spread throughout an area a little over 1 ha. in extent. A number of other small prehistoric sites near the Tretos are comparable in size and topographic setting. A second phase of use dates to Late Geometric through Classical times and is concentrated in two discrete locations, the northernmost associated with plentiful tile, blocks, and several pits exposed in section. The material includes much fine pottery, such as miniature Corinthian votive cups, Attic black- and red-figured and black-glaze wares, pithoi with impressed decorative bands and, in one case, a dipinto, and a Late Classical molded figure representing a bearded male. It seems possible that one function served by this site in Archaic and Classical times was that of a rural shrine. Despite the damage inflicted on the site by plowing, collection of artifacts from its surface using a grid of 10-m. squares has allowed clear spatial discrimination of the two main phases of its use.

2. Xenophon (Hellenica 7.2.1 and 7.3.5) mentions a border fort which the Argives fortified in their campaign against Phlius in 366 B.c. Some authorities have located it at our Site 101, atop the highest of the three peaks of ancient Mt. Trikaranon (Prophitis Ilias; Figs. 2 and 4), a key fortifiable position likely to have been of strategic importance at many periods in the past. ${ }^{68}$ Pottery and tile are abundant around the church of Prophitis Ilias, into the southwest wall of which has been built a small engaged Corinthian pilaster. The church itself is partly constructed from ancient blocks and includes two Byzantine capitals. To the southeast the road to the summit has been cut through ancient deposits, revealing in section a pit and a short stretch of well-built wall preserved two courses high, and there are other signs that structures and fortification walls survive at the site. The prehistoric period is faintly represented by two or three pieces of EH II urfirnis, and pottery of Roman and Byzantine date has also been recovered, but Archaic to Hellenistic (especially Classical) material is dominant. Some of the most diagnostic pieces are of the 4th or 3rd century B.c. The quality of the pottery, in general, is high; it consists mainly of black-glaze and blisterware shapes for eating and drinking, rather than domestic forms such as lekanai and mortars, and some of it may even be votive in character. Notable finds include a lead sling bullet of Classical to Hellenistic date and a silver coin of Stymphalos datable to ca. 431-370 B.c.

3. Investigations at Phlius have been of considerable importance (Figs. 2, 9, and 10), since the site represents the highest-level political center within the study area in GraecoRoman times and thus, not surprisingly, provides examples of types of material not well attested at rural settlements. Despite several campaigns of excavation by the American

${ }^{68}$ The site was noted by several 19th-century travelers. A. Frickenhaus and W. Müller (“Aus der Argolis,” $A M$ 36, 1911 [pp. 21-38], p. 23) described the ruins then as an inner fort with outer surrounding walls. For more recent discussion, see Pritchett, p. 104 and G. Gauvin, "Profitis Elias, un position clef au sommet du Trikaranon," Newsletter of the Canadian Archaeological Institute at Athens 9, 1980. 


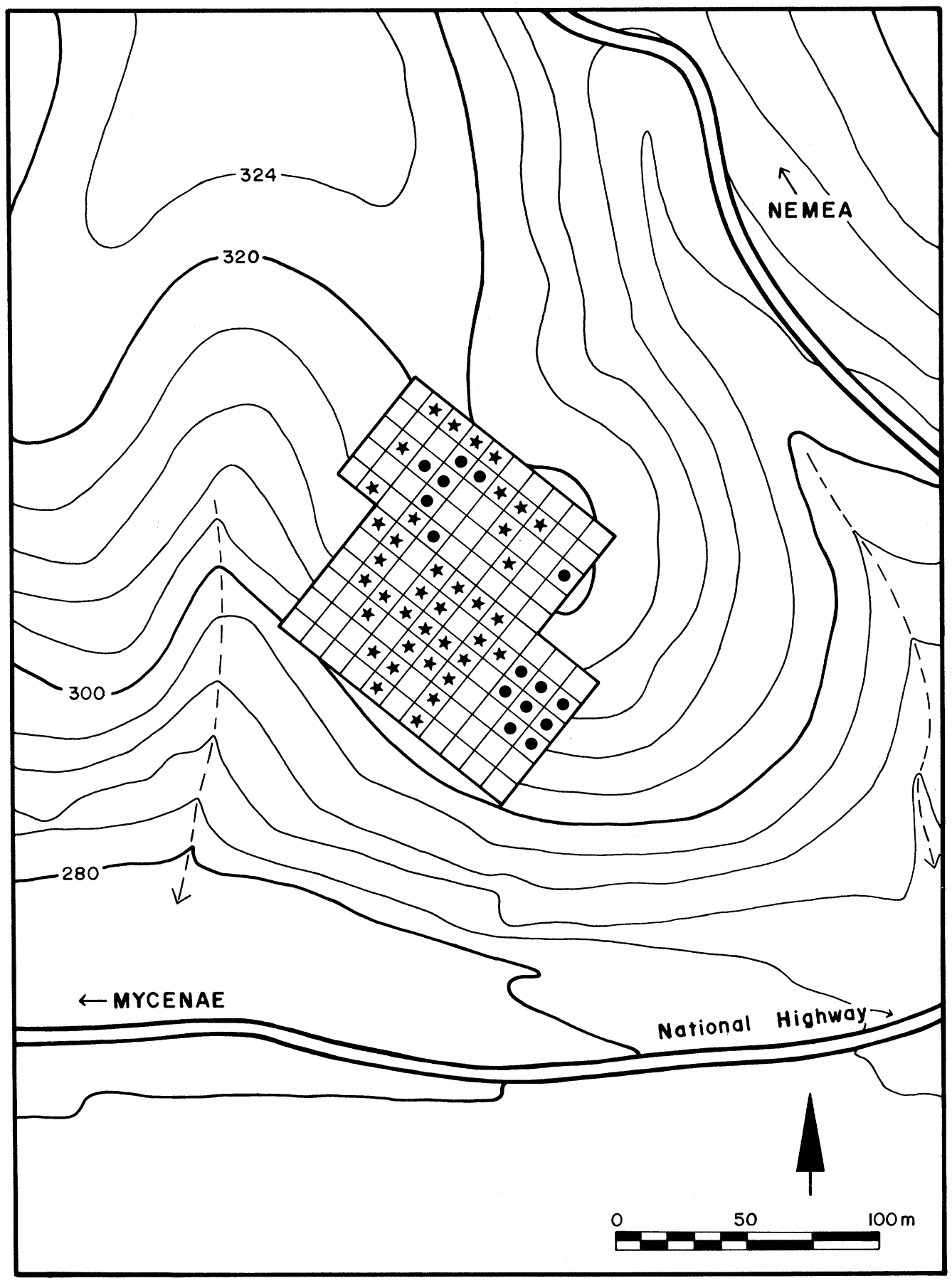

FIG. 8. Site 204, showing the survey grid and the distribution of prehistoric and Classical material (Jack Davis and Julia E. Pfaff). • Predominantly C-HL. $\star$ Predominantly EH 
School of Classical Studies, ${ }^{69}$ there existed no detailed map showing the surviving walls and other architectural remains over the extent of the site at different periods of its use. Accordingly, our work was designed to complement previous results by concentrating on several goals: 1) systematic mapping of architectural remains; 2) intensive collection of surface artifacts over much of the site and its immediate hinterland on the lower slopes of Prophitis Ilias to the east; and 3) establishing with greater precision the size of the settlement at different periods of its use and the degree to which the site shows discontinuity of the sort typical of other smaller sites in the area.

Conglomerate and poros blocks scattered in the fields (Fig. 9) are mostly from walls (the course of some of which can be traced most clearly on the acropolis), but architrave and column fragments, column capitals, bedrock cuttings, a statue base, and a Classical inscription were also recorded. Architectural finds are concentrated in the plain to the west and south of the acropolis near the area conventionally known as the "agora" and on the flat summit and west end of the acropolis itself, particularly in and around the chapel of Panagia Rachiotissa. No work was undertaken in the plain to the west of the acropolis, but previous excavation and casual inspection make it clear that many fragments of ancient structures exist there also.

Pottery densities (Fig. 10) mirror the southwestward bias of the architectural fragments. On the south, southeast, and northeast edges of the site, quantities of finds fall dramatically, and the limits of the ancient city in those directions now seem well defined. The western boundary of our study area lay at the Perivoli spring, southwest of the acropolis; pottery densities there remain quite high, and it is clear that the urban area continued farther west. Field-walking southeast of the acropolis on the slopes of Prophitis Ilias revealed a large continuous area of tracts with high-density concentrations of mainly Roman and Byzantine pottery; it appears that in late antiquity a settlement of very considerable size existed here on the outskirts of the Classical city. The pottery collected from the site of Phlius is generally similar to that known from earlier excavations. Neolithic, Early Helladic, and Late Helladic material was recovered in small quantities; the Mycenaean finds were a surprise, given previous assertions that the period was scarcely represented at the site. ${ }^{70}$ The wide distribution of Roman material, however, confirms the picture given by Pausanias of a flourishing community in the 2nd century after Christ; its quantity and variety offer a marked contrast with pottery from other sites occupied at this time. Among the more striking finds was a votive deposit containing hundreds of fragments of pottery and figurines dating from the Archaic and Classical periods (see p. 647 below; Pl. 96:b-d). These may have been dumped from a sanctuary on the acropolis but might equally well derive from a small extramural shrine. Also to the northwest of the acropolis, but lower

${ }^{69}$ For earlier excavations, see H. S. Washington, "Excavations at Phlius in 1892," AJA 27, 1923, pp. 428-446; C. W. Blegen, "Excavations at Phlius, 1924," Art and Archaeology 20, 1925, pp. 23-33; Meyer (footnote 67 above); Biers, 1969; Biers, 1971; Biers 1971, 1973, and 1975 (all cited in footnote 51 above). Work in the field was conducted under the direction of Dr. Susan E. Alcock. Biers led Wright on an historical tour of the site and provided archival material and much helpful advice for our researches.

${ }^{70}$ Biers, 1969, p. 457. 


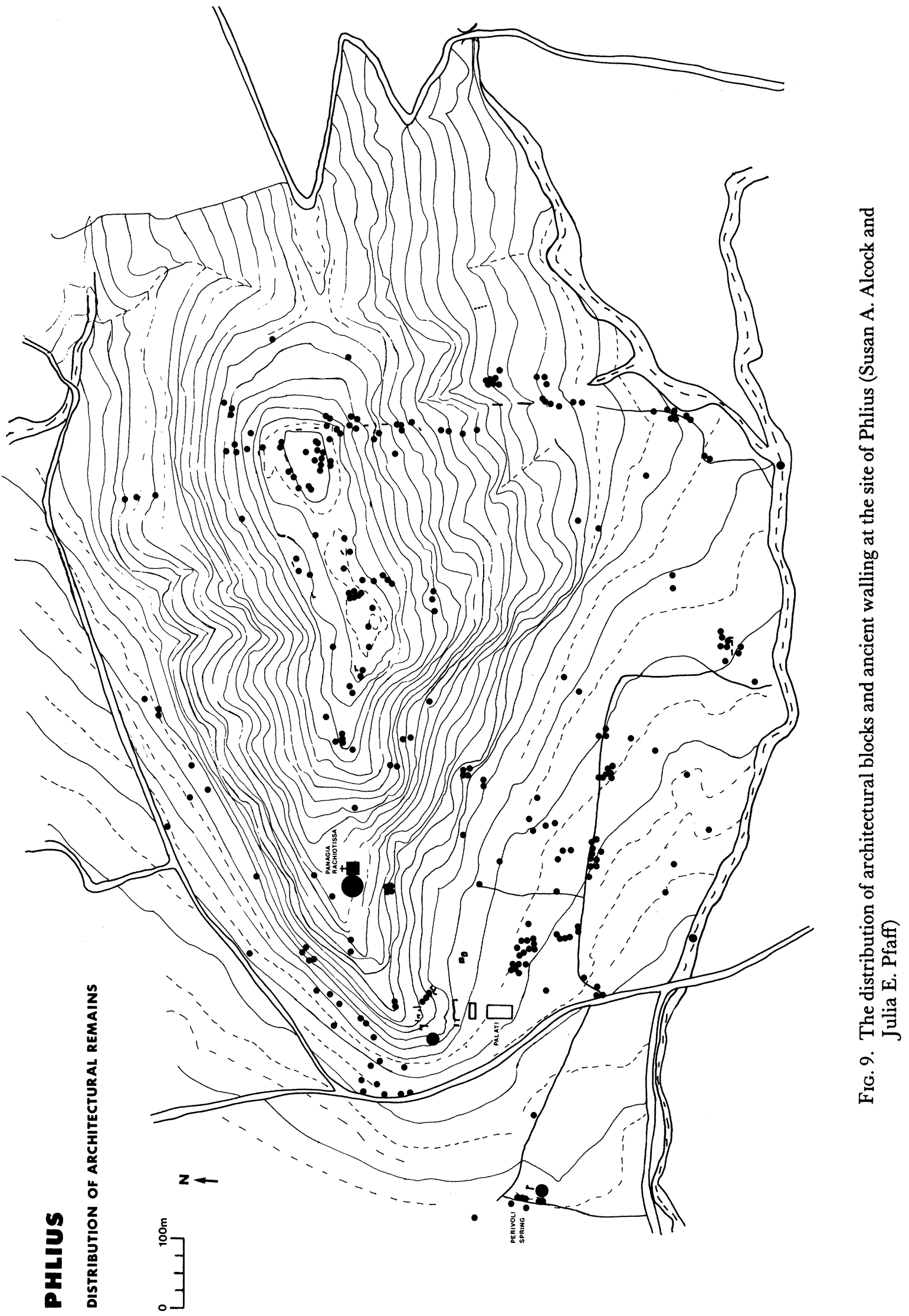




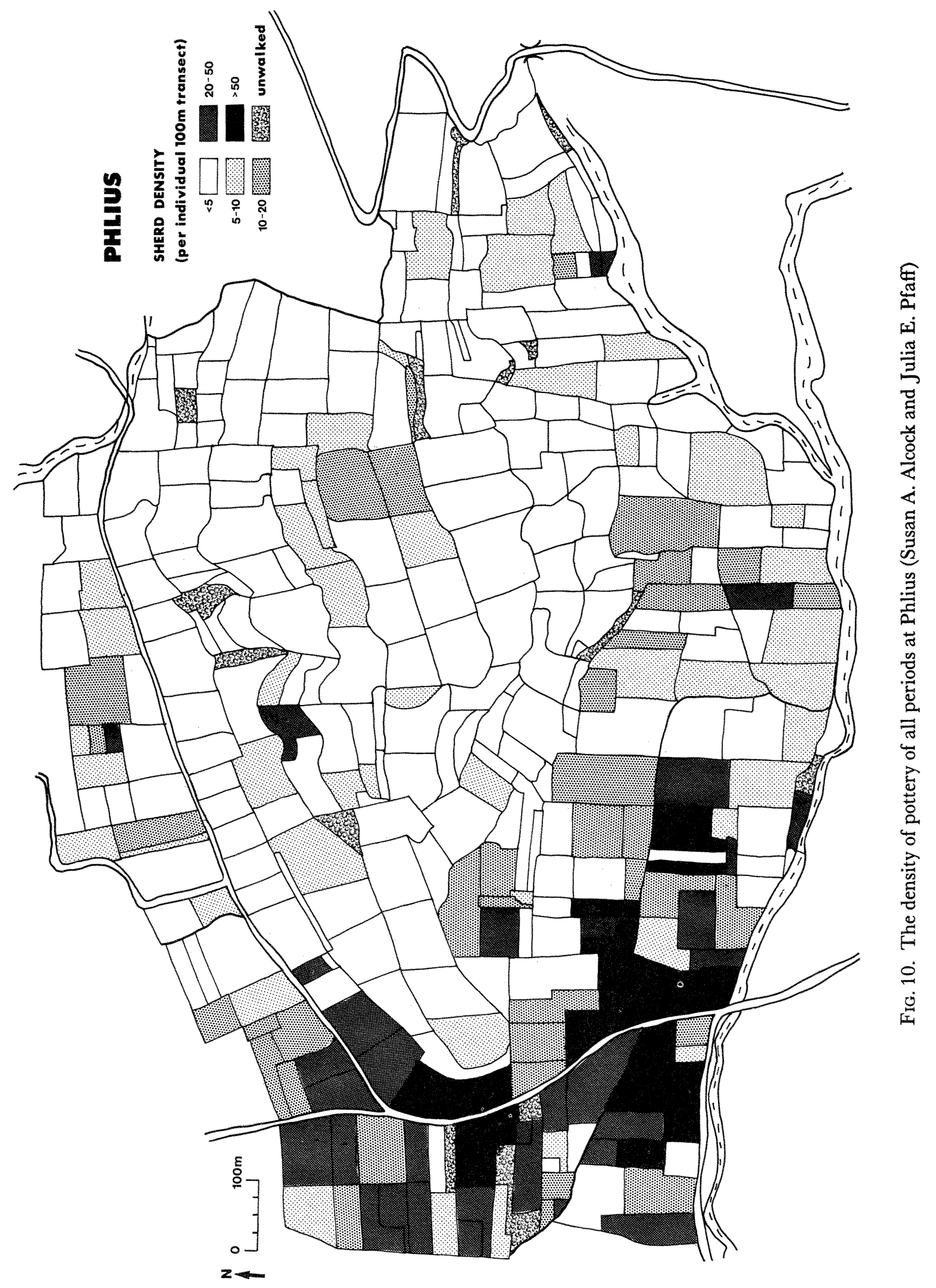


down at the edge of the plain, among human bones and pottery apparently from graves destroyed by the deep plow, were nearly complete vessels of the Early or Middle Geometric period (p. 647 below; Fig. 22).

4. Of outstanding importance among the many Mediaeval sites encountered is a complex of sites around the peak of Polyphengi, the precipitous mountain at the southern end of the Phliasian Plain, guarding what was until the 19th century the principal route south towards Argos. ${ }^{71}$ Its strategic significance is signalled by a Frankish (and later?) kastro, recently much disturbed by looters, atop the summit of the mountain (Fig. 4, Site 902). This is a small building, built of rough stone and tile, comprising a tower with basement-level rooms and adjoining structures. The kastro is approachable on the Nemean side only via a rock-cut tunnel through the summit cliffs; near by is an arched cistern, apparently of Frankish date. In the steep cliffs immediately beneath the summit of the mountain at its eastern end is a fortified rock shelter (Site 901), $40 \mathrm{~m}$. long. A curtain wall reaching from floor to ceiling was built across the entire mouth of the shelter, although this now survives only at its eastern end; its defensive character is indicated by a projecting semicircular bastion and a number of slit windows. The walls and ceiling were formerly plastered and decorated with frescoes, of which the single identifiable scene depicts the Presentation at the Temple and is probably of late 12 th-century date. ${ }^{72}$ This may well be the site of the original monastery, the first mention of which occurs in 1402; it was later replaced by the Monastery of Panagia tou Vrachou (Site 900), located at the foot of the 150-meter-high vertical rock cliff on the east side of the mountain. The monastery buildings incorporate numerous Middle and Late Byzantine ecclesiastical architectural members in marble, re-used from buildings presumably located elsewhere, and there are signs of several phases of architectural rebuilding and remodeling. The church contains poorly preserved wall and ceiling frescoes of Byzantine date, although the monastery is said to have been founded only in 1633. Above it lies a deserted Mediaeval village (Site 910), which occupies much of the sloping plateau to the east of the summit, overlooking modern Nea Nemea. The ground is covered by a nearly continuous spread of rubble from collapsed structures, probably both houses and churches, since early travelers reported the presence of as many as three dozen churches on Polyphengi. Other isolated structures have been noted farther west, including a probable watchtower or guardhouse commanding the route of ascent by the southeast ridge. Ceramic material from the village is of considerable interest, since the settlement, which is first mentioned in the Chronicle of Morea, seems to have been abandoned by the 17th century after Christ.

It will already be clear from the discussion above that for certain periods remarkably few chronologically diagnostic artifacts have come to light, while others are plentifully represented (Fig. 11). The periods for which little archaeological evidence seems to exist are the Late and Final Neolithic, the Middle Bronze Age, the Protogeometric and Geometric

71 The wide variety of archival and historical documents bearing on this cluster of sites have been discussed

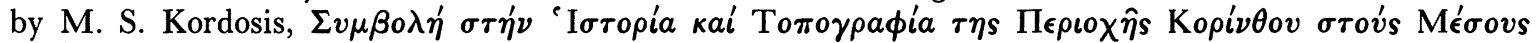
Xpóvovs, Athens 1981, pp. 176-184 and 368-372.

${ }^{72}$ We thank Robin Cormack for suggesting the date of the scene on the basis of examination of photo-

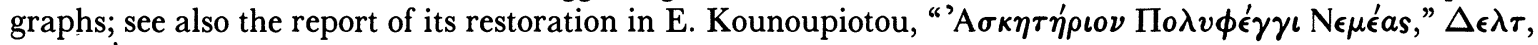
Xрovıк'a 26, 1971, p. 191, pl. 172:a, b. 
periods, and the Ottoman through early Modern eras. Later Hellenistic and early Roman material is very rare aside from a few big sites, but pottery of Late Roman date is more widespread. The fact that these periodic patterns are reflected in both tract and site collections (and, as noted above, that careful attention has been paid to the potential problems of surface visibility and geomorphological erosion or aggradation) inspires confidence in their reality, although they must remain somewhat imprecise and unquantified until our detailed studies are complete.

Sites occupied or in use during a single period only are unusual, most having produced material diagnostic of several, often widely separated, chronological phases. For instance, settlement and land use in all parts of the area during the 12th through 14th centuries after Christ seem to have been so intensive that almost every site, irrespective of its dominant period of use, has provided some material of Middle Byzantine to Frankish character. Similarly, prehistoric pottery, often no more than a few worn sherds, has been found at a high proportion of later sites. Detailed analysis will be necessary to determine whether such material represents either a significant prehistoric component masked by the remains of later occupation, or finds similar to those found "off site" in tract collections. Other surveys have often assumed, but not demonstrated, a picture of nearly uninterrupted settlement at favored locations. Our evidence suggests instead a much more dynamic and discontinuous pattern of ebb and flow in settlement, at the level both of individual sites and of the region as a whole.

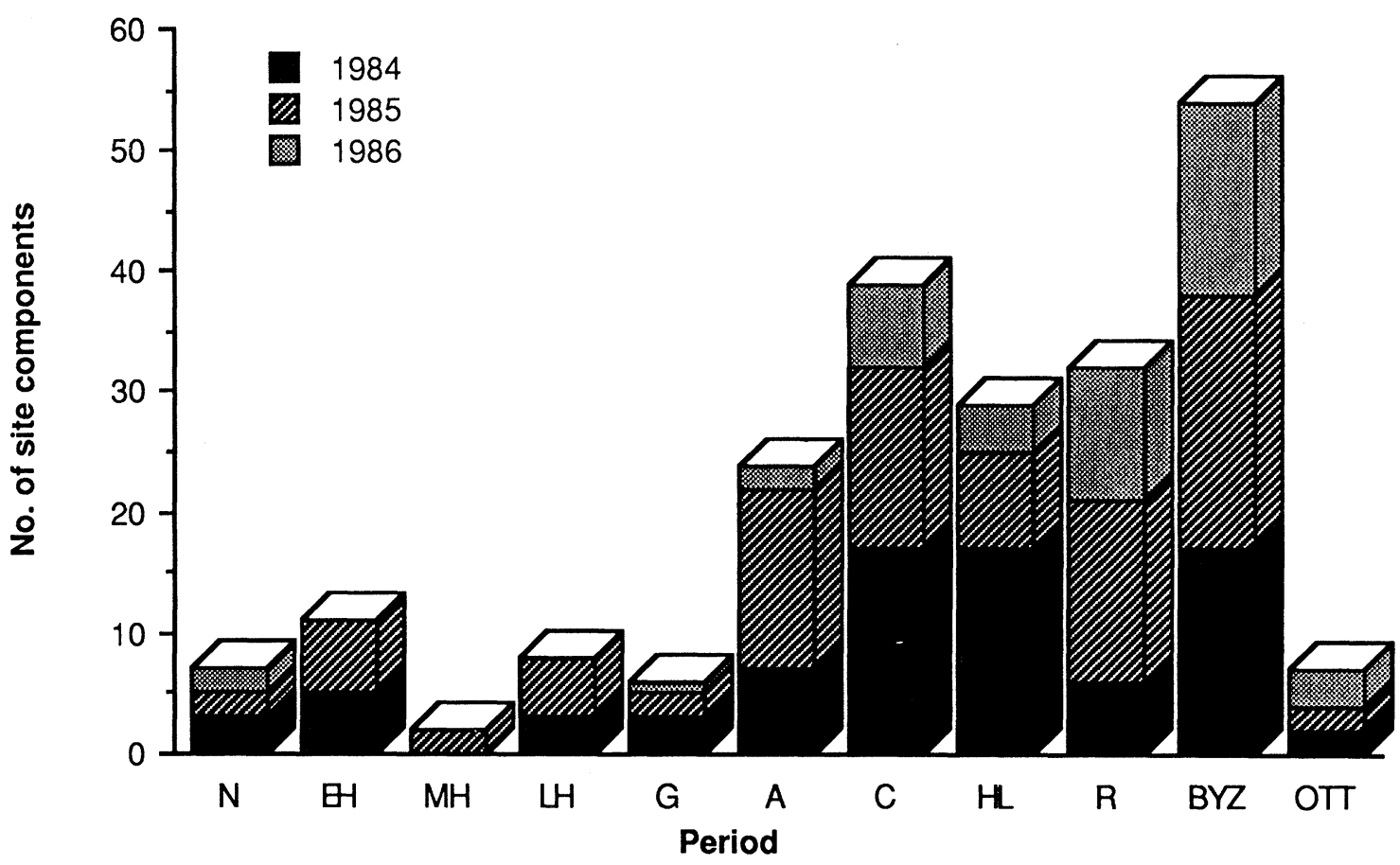

FIG. 11. Bar graph showing numbers of sites with components of different periods (John Cherry) 


\section{The Excavation on the Hill of Tsoungiza}

\section{Goals and Scope}

Excavation on Tsoungiza has had five major goals: 1) to determine as fully as possible the physical extent and chronological range of settlement; 2) to understand processes of site formation; 3) to examine the economic system of the settlement; 4) to relate the record of an excavated site to that recovered for comparable periods by survey; 5) to compare the phases of settlement on Tsoungiza to the pattern of settlement both within the study area and in the adjacent regions of the Corinthia and the Argolid. ${ }^{73}$ Each of these goals has required the development of specific methods for 1) recovering, recording, and analyzing excavated material; 2) recording artifact distributions over the site; 3) examining the geomorphology of the hill; 4) studying the environment of the site's resource area. ${ }^{74}$

Excavation on Tsoungiza began with the work of Carl Blegen and James P. Harland during the 1920's. In 1924-1925 Blegen excavated an extensive Neolithic deposit from the hill. ${ }^{75}$ In 1926 and 1927 Harland carried out extensive excavations of the Bronze Age settlement (Fig. 12), and their publication is another facet of NVAP. ${ }^{76}$ Salvage work in 1974, 1975, 1979, 1981, and 1982 uncovered further remains at the site. ${ }^{77}$ Although different standards of excavation and recording were employed by these earlier excavators, the reconstruction of a detailed and comprehensive understanding of the site's history has not been impaired.

\section{Methodological Overview}

Four strategies of data collection have been pursued: surface survey, remote sensing, excavation according to a grid of 1-sq.m. units, and sieving (including water sieving and flotation for collecting organic remains).

${ }^{73}$ This section of the report is by James C. Wright. Supervisors of Excavation Units were as follows: 1981, Mary Dabney (EU1); 1982, Anastasia Lambropoulou (test trenches); 1984, Nick Kardulias (EU2), Dr. Susan Petrakis (EU3), Elliott Lax (EU4), Professor Daniel Pullen (EU5), Professor Michael Toumazou and Anastasia Lambropoulou (EU6), Rebecca Mersereau (EU7); 1985, Dr. Nancy Leinwand and Nick Kardulias (EU2), Daniel Pullen (EU5), Rebecca Mersereau (EU7), Jennifer Tobin (EU8 and “Area L”), Kevin Glowacki (EU9), Michael Toumazou (EU10); 1986, Kevin Glowacki (EU2), Kathleen Krattenmaker (EU5), Rebecca Mersereau (EU7 and EU1), Keith Dickey and Natalia Vogeikoff (EU8), John Marszal (EU9), Marina Markantonatos (EU10 and EU11).

${ }^{74}$ Different components of these research objectives and strategy are discussed in Binford; K. W. Butzer, Archaeology as Human Ecology, Chicago 1982; M. B. Schiffer, "Toward the Identification of Formation Processes," American Antiquity 48, 1983, pp. 375-406; and, most recently, reviewed in Redman.

${ }^{75}$ Blegen, 1975.

${ }^{76}$ Harland. At his death in 1973, Harland left behind a nearly complete manuscript on the excavations. Completed during the 1930's, it had been reviewed by Blegen for publication along with other material from the early excavations in the Sanctuary of Zeus. This manuscript was willed to Professor George E. Mylonas, who kindly passed it on to Wright when he undertook the responsibility for the excavation of Tsoungiza. Harland also left a complete set of excavation notes, drawings, and photographs at the University of North Carolina, Chapel Hill. These were turned over to Wright by Professor G. Kenneth Sams. Wright thanks Professors Mylonas, Sams, and Stephen G. Miller for making this material available.

${ }^{77}$ Miller, 1975, pp. 150-152; 1976, pp. 174-177; Miller, 1980, pp. 37-40. 

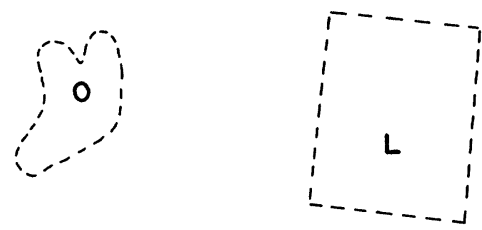

$x$
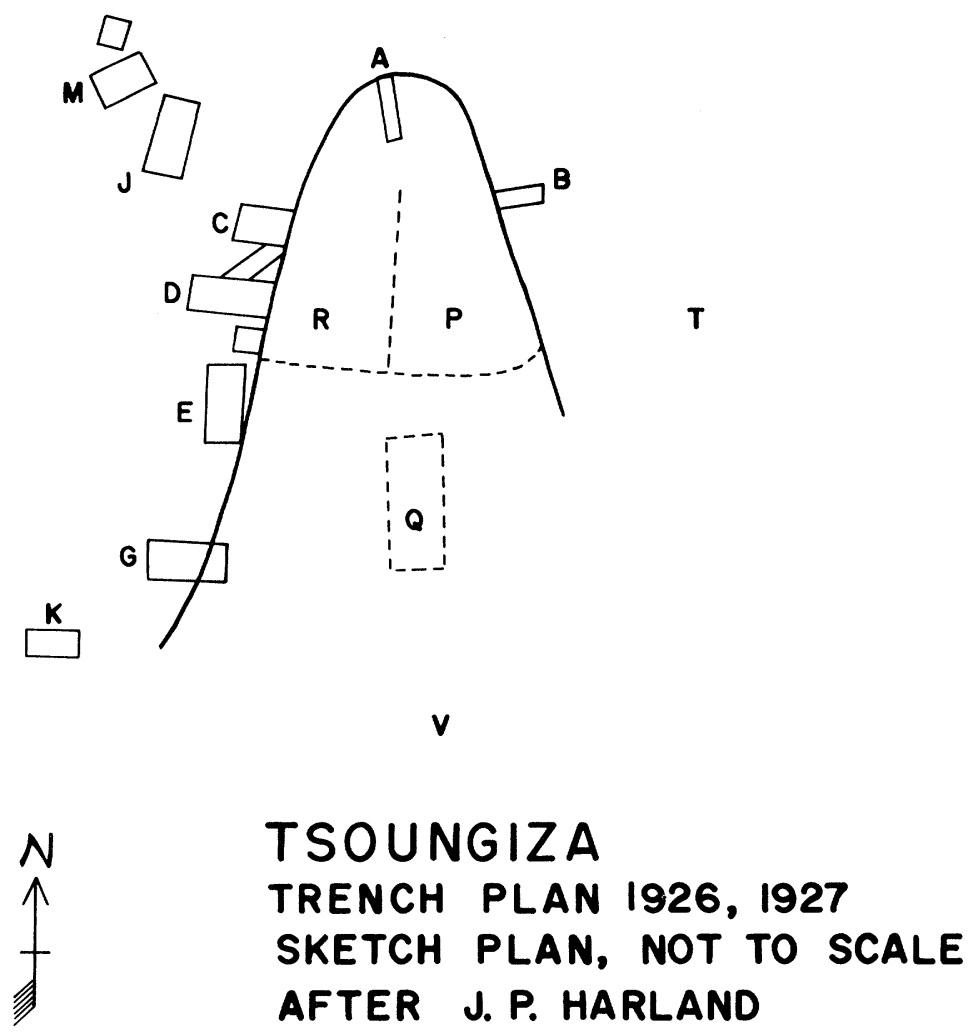

FIG. 12. Tsoungiza, sketch plan by J. P. Harland, 1927, showing approximate location of trenches (adapted by Julia E. Pfaff)

1. Surface survey offered an opportunity to study the relation of surface to subsurface artifact distributions. ${ }^{78}$ Because of the degree of disturbance by earlier excavation, this technique was not practical over the whole of the site and was therefore confined to the southern area (Fig. 13, Excavation Units [EU] 2, 3, 6, 7, 8), where all surface material was picked up in $1 \times 1 \mathrm{~m}$. units. An intensive survey using a $10 \times 10 \mathrm{~m}$. grid of the unexcavated areas of the site is planned for the future. A slightly less intensive investigation examined the peripheries of the site according to standard procedures (pp. 604-607 above).

${ }^{78}$ L. R. Binford et al., "Archaeology at Hatchery West, Carlyle, Illinois," Memoirs of the Society for American Archaeology, no. 24, 1970; C. L. Redman and P. J. Watson, "Systematic Intensive Surface Collection," American Antiquity 35, 1970, pp. 279-291. 


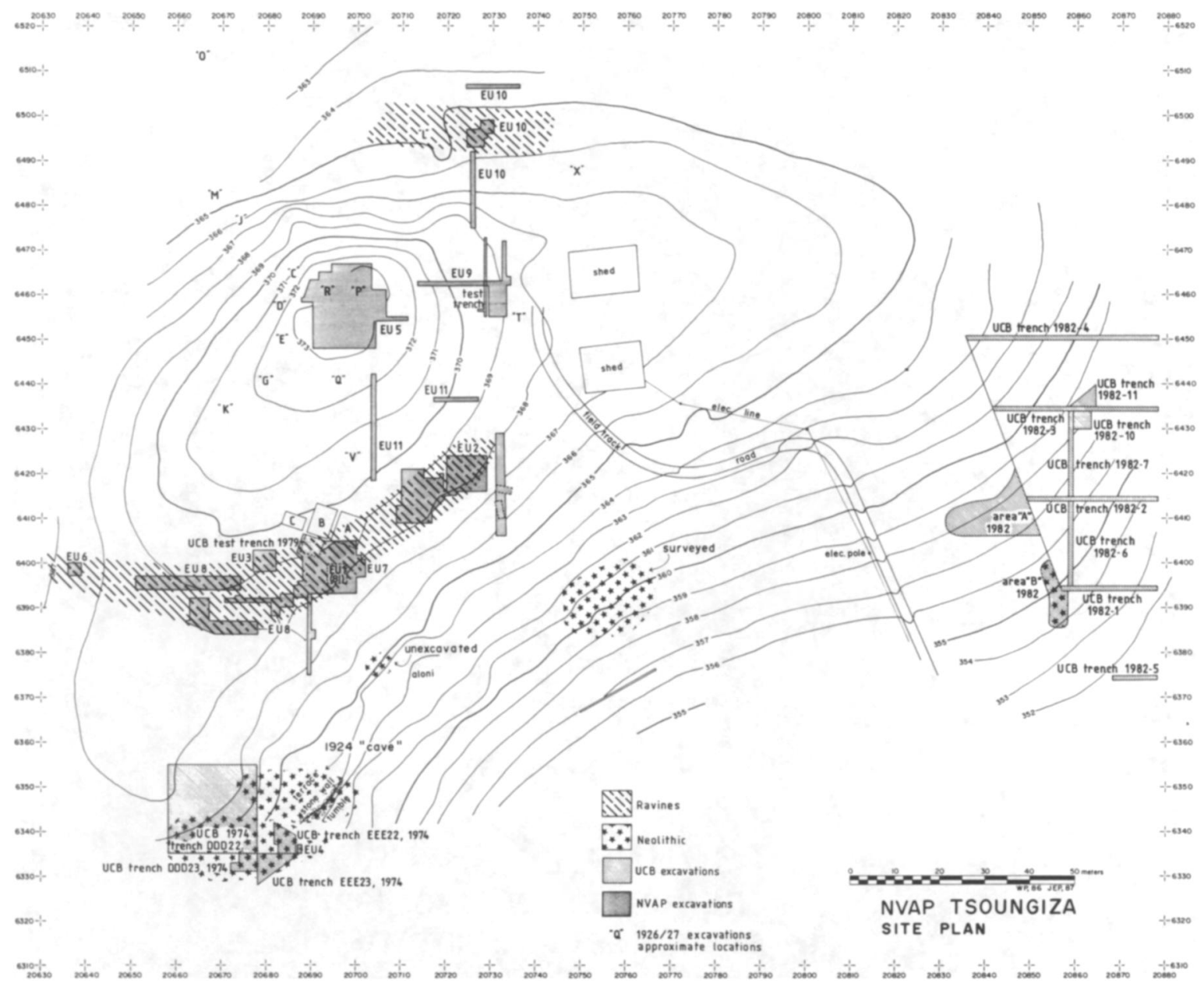

FIG. 13. Tsoungiza, plan of Excavation Units and earlier trenches, 1987. "UCB" refers to trenches of the University of California at Berkeley (Walter Payne and Julia E. Pfaff)

2. Experimentation with a variety of remote sensing procedures was carried out as a means of determining where to excavate. Extensive coring using a geological auger was conducted over the site. Cores were taken every 5 and $10 \mathrm{~m}$. along north-south and eastwest lines in order to determine the depth and type of stratigraphy and the depth of bedrock. This proved a quick and efficient means of learning about the stratigraphy of the site. In 1984 and 1985 limited areas of the site were inspected using a resistivity meter, and the preliminary results of this work were largely confirmed by excavation. ${ }^{79}$

${ }^{79}$ We thank Professor John Gifford for the loan of his auguring equipment and Dr. Kevin Pope for examining several cores in 1984. The resistivity work in 1984 was conducted by Mr. David Jordan of Bradford University, who offered his assistance while he was working with Professor Hector Williams at Stymphalos. In 1985 a more extensive resistivity survey was conducted by Mr. Carl Heron, presently at the University of Wales, who also supplied us with computer plot maps of the results. 


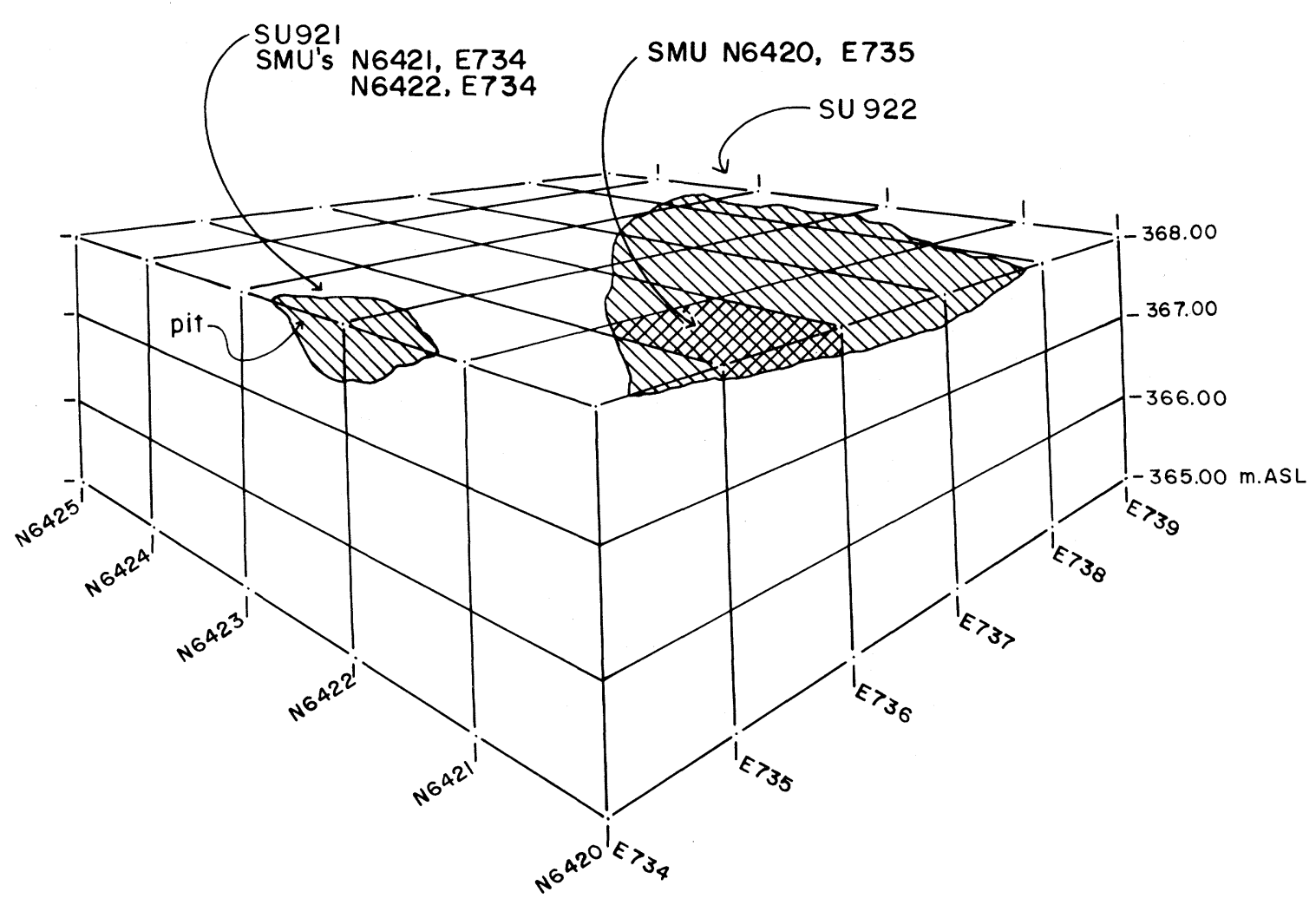

FIG. 14. Diagram of stratigraphic-grid recording system (James Wright and Julia E. Pfaff)

3. Excavation was carried out in units designated as Stratigraphic Units (SU) and Square Meter Units (SMU) within trenches called Excavation Units (EU). The SU is like the "basket" or "lot" of many American School excavations, or a "locus" elsewhere. ${ }^{80}$ It is defined as any discrete unit of excavation determined either arbitrarily or on the basis of observable stratigraphy. Constituent elements of most SU's are SMU's, which provide a means of spatial control in the horizontal dimension in much the same fashion as SU's, especially arbitrarily defined ones, do in the vertical dimension (Fig. 14). For example, often a pit or a floor may lose definition towards its edges; excavation and recording according to SMU's will preserve the evidence of this change. ${ }^{81} \mathrm{~A}$ further example will clarify the utility of the SMU. In EU2 (Figs. 13 and 15) a building of LH IIIB date was set directly over and into earlier occupation levels of late $\mathrm{MH}$ and (at least) LH IIB date. The compression of the stratigraphy was such that it was very difficult during excavation to isolate strata of different periods, particularly since the soils associated with artifacts of different date were essentially the same. Recording each SU according to units of 1 sq.m. successfully defined the location of

${ }^{80}$ W. G. Dever and H. D. Lance, A Manual of Field Excavation, New York 1978, pp. 75-80.

${ }^{81}$ E. C. Harris, Principles of Archaeological Stratigraphy, New York 1979; see pp. 40 and 111, discussion of "boundary contours". 


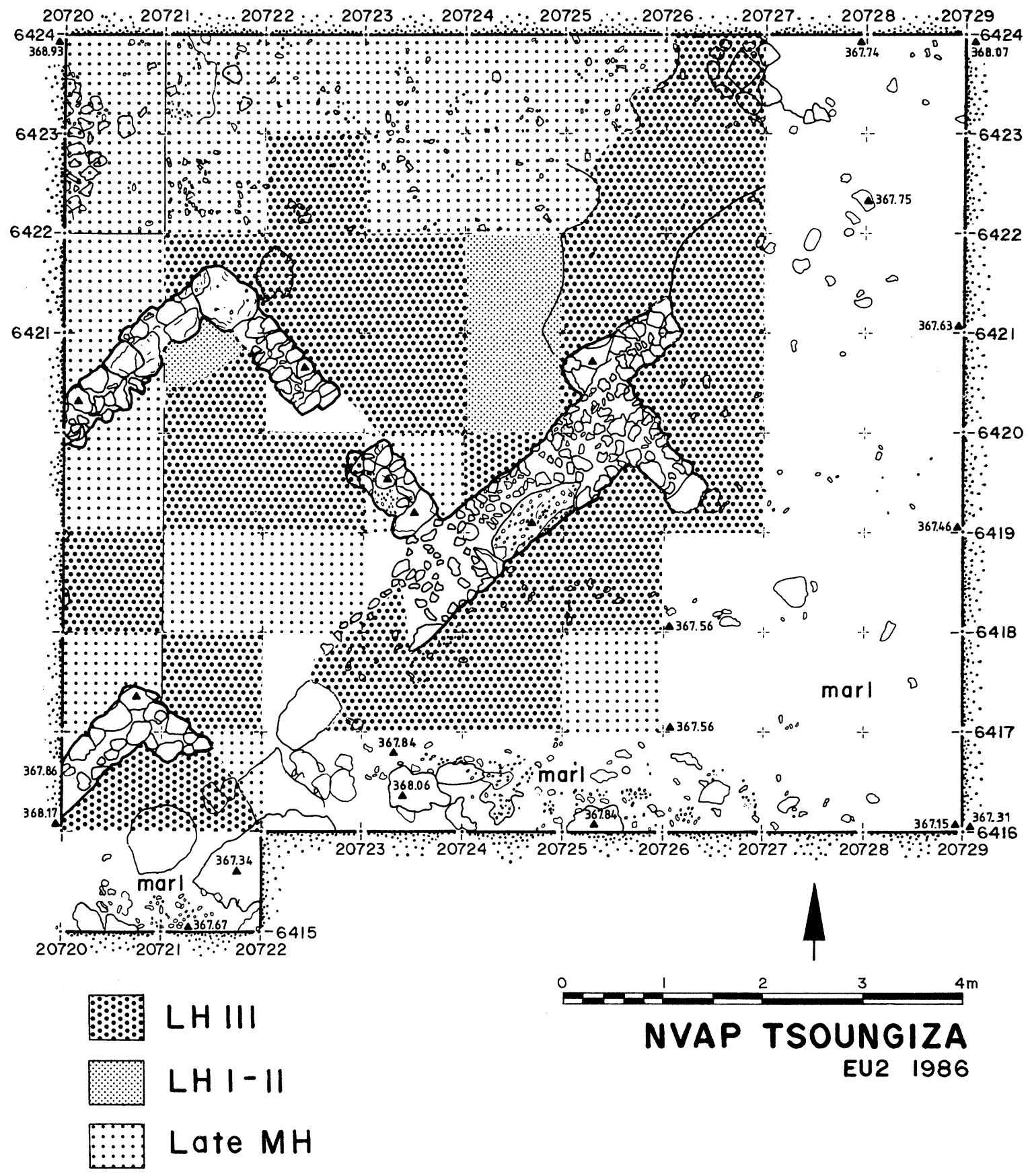

FIg. 15. Plot of distribution of ceramics in EU2 (James Wright and Julia E. Pfaff) 
LH IIIB ceramics, especially near the walls, where they probably were introduced when the foundations of the building were laid. Of course this system has many other uses, particularly for mapping the distribution of artifacts over the site.

4. All soil not disturbed by plowing was dry sieved through screens with a 5- to 7-mm. mesh. The finds were recovered and recorded in the appropriate SMU for their SU. Exceptions to this procedure were ashy or burned deposits, pits, and pot contents which were designated for water sieving and flotation. In such areas the soil was removed by SMU within SU, measured in volumetrically marked metal buckets (per liter), and then passed through a geological sample splitter to produce a 50-percent or 25-percent sample. Each sample was then again measured for volume before water sieving and flotation. In many areas of excavation one SMU was designated as a column for continuous sampling through all the stratigraphic horizons excavated. ${ }^{82}$

\section{Geomorphology}

Whereas today the hill of Tsoungiza appears to rise from its gently sloping southern and eastern sides to a knoll in the area of EU5, originally there were two knolls, one at the south and a higher one at the north. A deep ravine just north of the southern knoll separated them, while another ravine ran around the north side of the higher knoll (Fig. 13). ${ }^{83}$ The evidence for the ravines was found in EU2, EU3, EU6, EU7, and EU8 at the south, and EU10 at the north. In each, soundings reached the marl bedrock of the hill and, where the sides of the ravine were exposed (EU3, EU7, and EU8), permitted a calculation of its slope. Two other soundings, in EU6 and EU10, plumbed its depths.

Deposits in the southern ravine appear to be dumped fills, roughly stratified with EH II material mixed with some Neolithic at the bottom, with thicker accumulations of EH III above, and on top late MH and LH I. Anne Demitrack and Tjeerd van Andel have suggested that most of these fills were introduced suddenly; no strata attributable to continuous deposition were detected. The artifacts atop the fill, which was ground level during late $\mathrm{MH}$ /early LH I, are large and unworn.$^{84}$ It seems that the inhabitants of the site used the ravine surface for dumping. The fill of the north ravine is quite similar, consisting in EU10

${ }^{82}$ G. L. Cowgill, "A Selection of Samplers: Comments on Archaeo-statistics," in Sampling in Archaeology (footnote 50 above), pp. 258-284; J. Hansen, "Palaeoethnobotany in Greece," in Contributions to Aegean Archaeology (footnote 8 above), pp. 171-181; eadem, "Agriculture in the Prehistoric Aegean: Data versus Speculation," $A J A 92,1988$, pp. 39-52. The sample splitter employed was a Porta-Splitter, manufactured by the Gilson Corporation, Worthington, Ohio. Dr. Charles K. Williams, II generously lent us the water sieve of the Corinth Excavations; it is a modified Ashvan type (S. Diamant, "A Short History of Archaeological Sieving at Franchthi Cave, Greece," JFA 6, 1979, pp. 203-217). The development and implementation of this system was done in consultation with Professor Julie Hansen.

The standard sampling procedure for water sieving was as follows: for ashy or burned deposits, 50 percent of each SMU (unless very extensive, then 25 percent); for pits, 25 percent; for isolated patches of burnt or heavily organic strata and pot contents, 100 percent.

${ }^{83}$ Anne Demitrack has pointed out that these ravines are actually karstic formations frequently found in the Neogene marl of the region. When exposed they are easily eroded by natural processes.

${ }^{84}$ Rutter. 
of a basal unit of EH II covered by a thick fill of EH III that may have been crowned by EH III structures, to judge from Harland's notes (p. 629 below). There follows a mixed fill deposited in late $\mathrm{MH}$ times overlain by a shallow LH I fill and a deep deposit of LH IIA occupation debris associated with architecture.

It is clear that the ravines were open during the Neolithic and Early Bronze ages. During the initial phases of the EBA the settlement was based directly on the marl bedrock, while considerable fill was introduced into the ravines during EH II and especially EH III. Still earlier, during the Neolithic, the settlement may have been based on topsoil rather than the marl, as remnant red topsoils of probable Neolithic date have been recognized in isolated pockets of the site today. ${ }^{85}$ Such cover, however, would not have lasted long once the hilltop became inhabited.

With regard to the Neolithic period, one other geomorphological feature of the site is significant. When Blegen excavated in 1924 he described Neolithic remains located in a "cave", extending some 20 meters east to west, up to 6 meters wide, and varying in depth from 4.5 to 6 meters. ${ }^{86}$ Salvage work in 1974, 1975, 1981, and 1982 disclosed similar Neolithic deposits in smaller cavities in the marl. These are located both on the southern end of the hill and along the slopes to the southeast (Fig. 13) ${ }^{87}$ Investigation of them has disclosed no remains of habitation in situ, a situation not unlike that observed in pits at site $702 .{ }^{88}$

\section{General Character of Settlement Phases}

Prior to the inception of NVAP the location and date of different phases of settlement were generally known. Neolithic material was considered Early Neolithic in date, although traces of Middle Neolithic had also been recognized in the deep cavities in the marl at the southern slope of the site ${ }^{89}$ Early Helladic II and III architecture and finds were known from the crown of the hill. ${ }^{90}$ Early Mycenaean architectural phases were recognized on the plateau at the north of the crown (Fig. 18), while LH IIIB architecture had been exposed in salvage work in 1979 on the mid-southern slope, and a uniform LH IIIB:1 assemblage of pottery was found mixed with Neolithic at the south (Fig. 13). ${ }^{91}$ Missing components were LN, EH I, MH, and LH IIIA. Since 1981 excavations have expanded the range of inquiry at Tsoungiza by systematically exploring the entire site for all periods of occupation. The results have considerably refined our understanding of the phases and extent of occupation.

The earliest settlement on Tsoungiza was founded during the EN and continued into the MN period. Although no architectural remains have been found in situ, finds of daub

${ }^{85}$ Cherry et al., 1988.

${ }^{86}$ Blegen, 1975, p. 255.

${ }^{87}$ Miller, 1976, p. 176, fig. 2, pl. 29:c; Miller, 1982.

${ }^{88}$ Cherry et al., 1988.

${ }^{89}$ Blegen, 1931, p. 55; Blegen, 1975, p. 259, note 18, p. 277 , note 40.

${ }^{90}$ Harland.

${ }^{91}$ Miller, 1975, pp. 151-152, pl. 34; Miller, 1976, p. 177, pl. 29:b. The salvage work (reported in Miller, 1980, pp. 203-205) was carried out by the Greek Archaeological Service, under the direction of Ms. Konstantina Kaza, who is presently preparing the material for publication. 
with a cane impression demonstrate the existence of structures. ${ }^{92}$ Ground-stone tools, animal and human bone remains, seeds, and pottery from the Neolithic levels also indicate the presence of settlement. These deposits from the pits in the marl slopes and the sporadic discovery of Neolithic finds elsewhere on the hill suggest a widely dispersed settlement, perhaps located along the southern and southeastern slopes of the ridge (Fig. 13). A few stratigraphic units of purely Neolithic or mixed N-EH from the crown of the hill may derive from habitation there.

Restudy of the Neolithic pottery has brought to our attention the presence of considerably more finds of MN date than Blegen recognized, with close parallels to Lerna II and the second phase of the $\mathrm{MN}$ at Franchthi. ${ }^{93}$ Also, within the material published by Blegen are a few pieces of LN and FN to EH I, but it does not appear that a settlement existed during the $\mathrm{LN}$ period. ${ }^{94}$

Resettlement probably occurred during the transition from the Final Neolithic to the Early Bronze Age, apparently on the crown of the hill (Pl. 93:b). Scattered but plentiful FN/EH I and pure EH I ceramic deposits have been found in pits there. ${ }^{95} \mathrm{~A}$ deep cistern cut into the marl in the northern part of EU5 (Fig. 16, E20696, N6462, Cistern 2) has abundant EH I pottery. Although a direct stratigraphic sequence linking the FN, EH I, and EH II levels has not been found, the EH I cistern lies beneath a series of strata and floors of middle EH II date in EU5. ${ }^{96}$ Early EH II material is represented by the remains of a building excavated in 1982 in a field on the eastern slope of the hill. ${ }^{97}$ A large floor deposit in a burnt room in the northern area of EU5 (Pl. 94:a) preserved much material of the

\footnotetext{
92 The daub, from EU4, was recognized by Rebecca Mersereau, who is studying the building materials and construction techniques of the structures found on Tsoungiza. Cf. the MN daub recovered from site 702: Cherry et al., 1988, p. 170.

${ }^{93}$ We thank Professor K. D. Vitelli of Indiana University for her expert identification of much of this material; Drs. William W. Phelps and Maria Pantelidou provided their expertise as well. Blegen was aware of the presence of MN at Tsoungiza: Blegen, 1931, p. 55, and Caskey's comments in Blegen, 1975, p. 259, note 18 and p. 277, note 40. This material is being readied for publication by Ms. Anne Kugler.

${ }^{94}$ From the excavations by Blegen: FN: a red-burnished body fragment with wedge-shaped incisions in a raised band (Blegen, 1975, p. 278, pl. 68, no. 4; Nemea Museum P 1376); FN/EH: two red-burnished fragments from an "oven" (Blegen, 1975, p. 278, pl. 68, no. 8 [called a "scoop"]; Nemea Museum P 1381; p. 275, pl. 64, no. 34, Nemea Museum P 1371).

${ }^{5}$ LN: 2115-2-5, from Cistern 2; 2013-2-1, a Gonia polychrome body sherd (Blegen, 1931, p. 55). From the same deposit (Pit 32, SU's 2011-2014) as this last piece are several EN and MN sherds.

EH I: Pit 17 (SU's 822, 826, 829, 830), Pit 18 (SU 100), Pit 31 (SU's 891-894), Pit 32, (SU's 2011-2014), Pit 48 (SU's 1960-1964, 1967-1969), Pit 51 (SU's 2024-2025), Pit 55 (SU's 1935, 1936, 1938-1941), Pit 65 (SU's 2029-2031), Cistern 2 (SU's 2100-2121). See D. J. Pullen, “An Early Bronze Age Village on Tsoungiza Hill, Ancient Nemea," in L'habitat égéen préhistorique (BCH-Suppl.), R. Treuill and P. Darcque, edd., in press, and idem, "The Earlier Phases of the Early Bronze Age at Tsoungiza Hill, Ancient Nemea, Greece," $A J A 92,1988$, p. 252 (abstract); for comparanda, see now A. Dousougli, "MakrovouniKefalari Magoula-Talioti. Bemerkungen zu den Stufen FH I und II in der Argolis,” PZ 62, 1987, pp. 164-220.

The evidence of EBA settlement on the site is being studied by Pullen; he has supervised the excavations of EU5.

${ }^{96}$ Pullen, "Early Bronze Age Village" (footnote 95 above).

${ }^{97}$ Miller, 1982; Pullen, op. cit.
} 


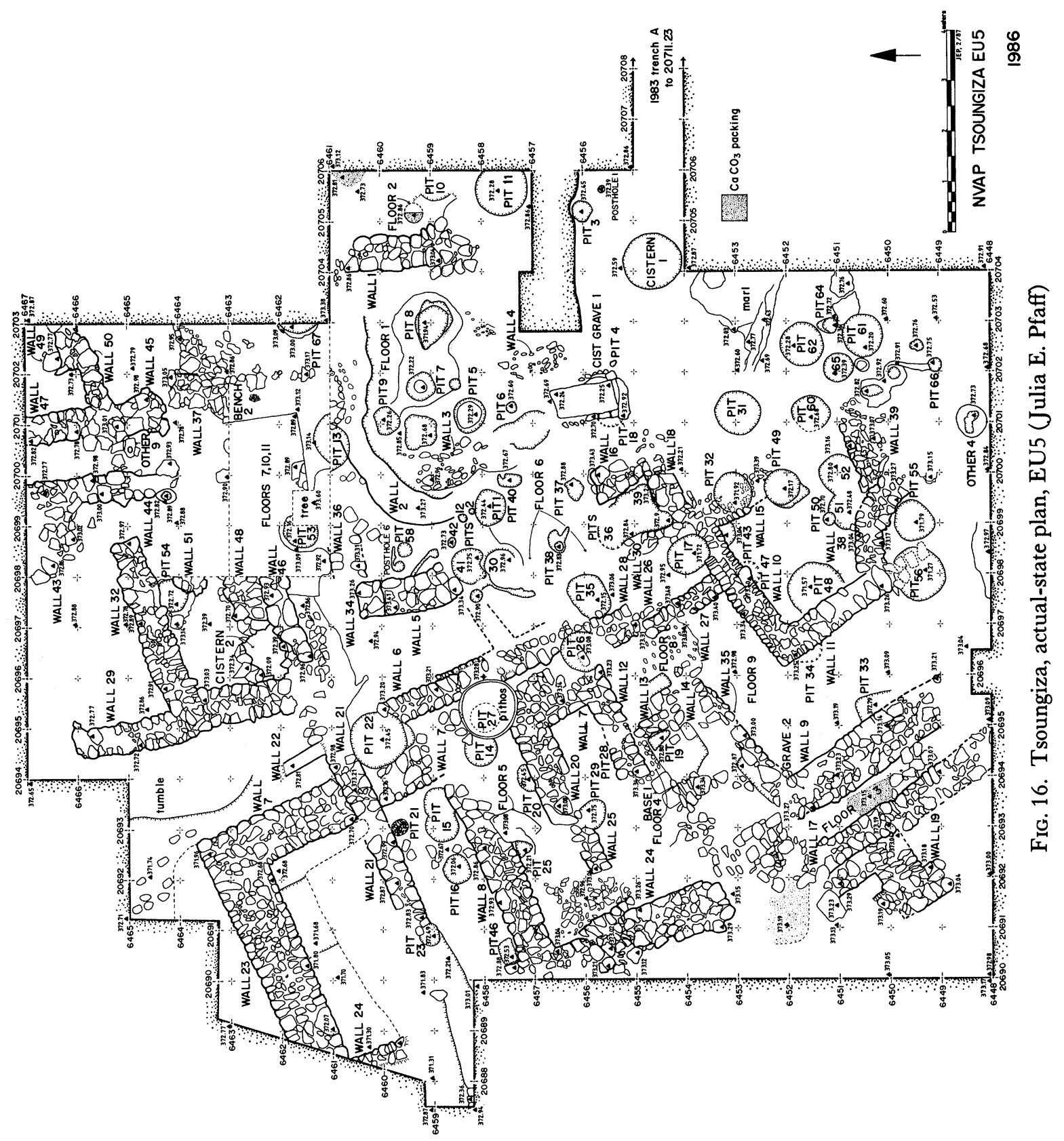




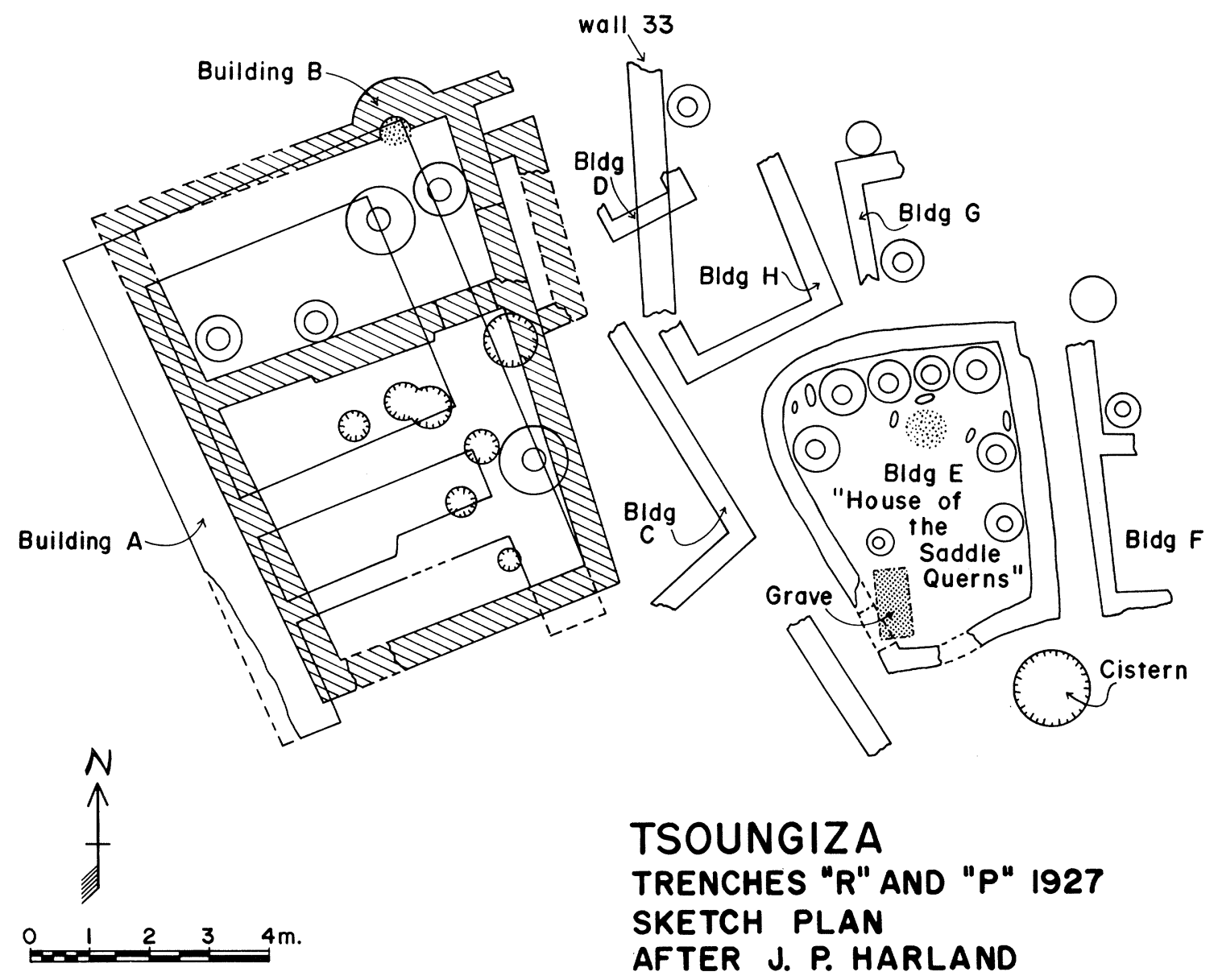

FIG. 17. Tsoungiza, sketch of EH structures, 1926-1927 (adapted by Julia E. Pfaff from a plan by J. P. Harland)

middle phases of EH II, ${ }^{98}$ while other remains of this period are associated with architectural remains (Harland's Buildings A and B, Fig. 17) and in some pits (e.g. Pit 56, Pl. 94:b). The latest phases of EH II, i.e., Lerna III, phase D, have not been identified anywhere on the site. ${ }^{99}$

During this period the settlement seems to have developed in complexity so that by early EH II a number of structures were located on the crown of the hill and down the slopes. An EH I-II building located $c a .150 \mathrm{~m}$. southeast of the top of the hill was built into a cutting in the marl bedrock of the hill (Fig. 13, Area "A"). ${ }^{100}$ On the crown, Building A, discovered by

${ }^{98}$ E.g., SU 757, material comparable to Lerna III, Phase C.

${ }^{99}$ We wish to thank Dr. Martha $\mathrm{H}$. Wiencke for her comments on this material and its relation to that from Lerna.

${ }^{100}$ D. J. Pullen, "The Early Bronze Age Settlement on Tsoungiza Hill, Ancient Nemea," in Early Helladic Architecture and Urbanization (SIMA 76), R. Hägg and D. Konsola, edd., Göteborg 1986, pp. 73-78, fig. 64. 
Harland (Figs. 16 and 17), is very substantial, with walls $c a .1 \mathrm{~m}$. thick and deep foundations forming a terrace at the north. Numerous tiles found fallen down the slope to the east (in EU9) and also scattered over most of the slopes of the hill may have come from this building, which Pullen has identified as an architectural forerunner of the Lerna House of the Tiles type of building. ${ }^{101}$ As such it would presumably reflect a process of increasing socio-economic centralization at the site. Signs of increased wealth and contact with exchange systems are illustrated by a number of imports or luxury items roughly assignable to this period: stone vessels (Pl. 94:c), a conical lead stamp seal (a unique find on the mainland: Pl. 94:e), bronze tools (Pl. 94:d), and numerous lead clamps. ${ }^{102}$ After the abandonment of this building another, also of EH II date, was built partly over its foundations (Building B, Fig. 17). One EH burial, a unique rectangular cist grave discovered by Harland at the southwest of Building E, was cut into the marl and covered with slabs (in grid E20701, N6455, Fig. 16). ${ }^{103}$ Elsewhere on the site few traces of contemporary structures have been found. Early Helladic II pottery from basal units in EU10 to the north is probably debris washed from the settlement on the top of the hill. To the east are only tiles and an occasional sherd, while along the southern slopes in EU2, EU7, and EU8 are traces of walls and pits cut into the marl.

The site was abandoned within EH II and reoccupied after EH III was well underway (Lerna IV, Phase 2). ${ }^{104}$ This settlement was short-lived and did not continue into the Middle Helladic period. On top of the hill a completely preserved curvilinear structure (Harland's House E) was surrounded by other buildings only partially preserved (Harland's Buildings D, F, G, and H; Fig. 17). In front of building $\mathrm{E}$ was a cistern, which Harland, thinking it a well, excavated to a depth of $12.25 \mathrm{~m}$. without reaching bottom. ${ }^{105}$ Within building $\mathrm{E}$ were seven storage vessels, seven ground-stone tools, and numerous vessels and

In 1981 and 1982 this area was salvaged by the University of California at Berkeley project under the direction of Professor Stephen G. Miller. R. Sutton began the work, which was then finished in a separate campaign by Pullen and Dr. Robert A. Bridges, who carefully tested the entire field and meticulously recorded the remains in the area.

${ }^{101}$ D. J. Pullen, "A 'House of Tiles' at Zygouries? The Function of Monumental Early Helladic Architecture," in Hägg and Konsola (footnote 100 above), pp. 79-84 and idem, "Early Bronze Age Village" (footnote 95 above); cf. J. Shaw, "The Early Helladic II Corridor House, Development and Form," AJA 91, 1987, pp. 59-79; of the tiles, the most numerous fragments were preserved in a LH IIIA:2 context in EU9, but others come from EH levels in EU7.

${ }^{102}$ Frying pans: J. Coleman, “'Frying Pans' of the Early Bronze Age," AJA 89, 1985, pp. 191-219, no. 114, p. 216. In addition to this example, others have been found; a complete listing is as follows: 814-2-6, 822-2-15, 2011-2-2, 2013-2-2, 2014-2-1. Stone vessels: steatite lid, 745-8-1 (Pl. 94:c); marble lid, 745-8-2. Bronze tools: dagger, 2016-5-1 (Pl. 94:d). Lead stamp: 890-5-1 (Pl. 94:e). Lead clamps: a total of 19 clamps have been found in various contexts extending from $\mathrm{EH}$ through $\mathrm{LH}$; metallurgical analysis and study of context will determine which are of EBA manufacture.

${ }^{103}$ D. J. Pullen, "Mortuary Practices in Early Bronze Age Greece: Identifying Patterns of Prehistoric Behavior," $A J A 90,1986$, p. 178 (abstract).

${ }^{104}$ For the tripartite division of Lerna IV see J. B. Rutter, “A Group of Distinctive Pattern-Decorated Early Helladic III Pottery from Lerna and Its Implications,” Hesperia 51, 1982 (pp. 459-488), p. 461 and note 6.

${ }^{105}$ Our geologists have pointed out that the aquifer which would have supplied this well is more than 30 meters below the surface of the hilltop, making it inconceivable that this shaft or the one to the northwest could have been a well. 
other finds scattered over the floor, the most notable of which is a terracotta mold for a chisel (Pl. 94:f). From the well came Fine Gray-burnished ware, fragments of patterned incised vessels, e.g. a pedestal-footed shallow cup (Pl. 94:g), ${ }^{106}$ and sherds of patterned ware.

To the west of this group stood a large but poorly preserved building, C. Down the slope in the fill of the ravine to the north, Harland uncovered a rectangular building (Fig. 12, Trench "L"; Fig. 18, Building J). His notebook records sherds of "Minyan" and patterned ware from this building. Since the recent work has recognized no such $\mathrm{MH}$ pottery from the site, and as Jeremy Rutter has pointed out, the ceramics identified by Harland as Gray Minyan are actually Fine Gray-burnished ware, Building J should be dated to the EH III period. ${ }^{107}$ East of EU5 were no traces of EH III remains, while on the southern side of the ravine in EU7 two pits and traces of two walls datable to the EH III period were found (Fig. 19, walls 26 and 29 in grids E20696/7, N6397/9; E20699, N6395; E20698, N6393).

Although the density of architectural arrangements atop the hill and the distribution of settlement remains over the site indicate an active settlement during the EH III period, and although the ceramic remains are typical of the production centers of the Argolid, the lack of rare and specialized imports suggests that the inhabitants were not so frequently in contact with outside areas as were those of the EH II phase settlement, and the absence of a central, dominant building such as existed in Building A of the EH II period supports this view.

Throughout the Middle Bronze Age the site was again abandoned until the late $\mathrm{MH}$ phase, contemporary with the earliest graves of Circle B at Mycenae, ${ }^{108}$ when settlers reoccupied the hill. The major activity that can be associated with the initial phase of settlement is the infilling of the ravines, and finds of late $\mathrm{MH}$ date were strewn over the surface; ${ }^{109}$ it is probable that a structure uncovered in the southwestern corner of EU7 was then erected (Fig. 19). To the northeast, in EU2, an extensive contemporary deposit of carbonized grape pips was associated with collapsed mud brick and burning, possibly evidence of wine production, since they were concentrated within a small area (as if gathered in a basket) and because about half are probably from domestic grapes. ${ }^{110}$ Along the north side of EU2 (Fig. 21) surfaces of late $\mathrm{MH}$ date were discovered much disturbed by activity of the late LH IIIB period.

So far as we know from excavation, the early Mycenaean buildings were clustered on and perhaps above the flat terraces created by filling the southern and northern ravines. In both places settlement continued throughout the entire Mycenaean period. Other areas

\footnotetext{
${ }^{106}$ Rutter (footnote 104 above), nos. 12, 14, pp. 465, 474-475.

${ }^{107}$ J. B. Rutter, "Fine Gray-burnished Pottery of the Early Helladic III Period: The Ancestry of Gray Minyan," Hesperia 52, 1983 (pp. 327-355), p. 339.

${ }_{108}$ O. T. P. K. Dickinson, The Origins of Mycenaean Civilisation (SIMA 49), Göteborg 1977, pp. 40-46; S. Dietz, Asine, II, Results of the Excavations East of the Acropolis, 1970-1974, fasc. 2, The Middle Helladic Cemetery and Early Mycenaean Deposits, Stockholm 1980, pp. 141-144; and especially now G. Graziadio, "The Chronology of the Graves of Circle B at Mycenae: A New Approach," AJA 92, 1988, pp. 343-372 and Rutter.

${ }^{109}$ Rutter; see especially the discussion of EU6.

${ }^{110}$ J. Hansen, "Bronze Age Agriculture in the Nemea.Valley," AJA 92, 1988, p. 253 (abstract).
} 


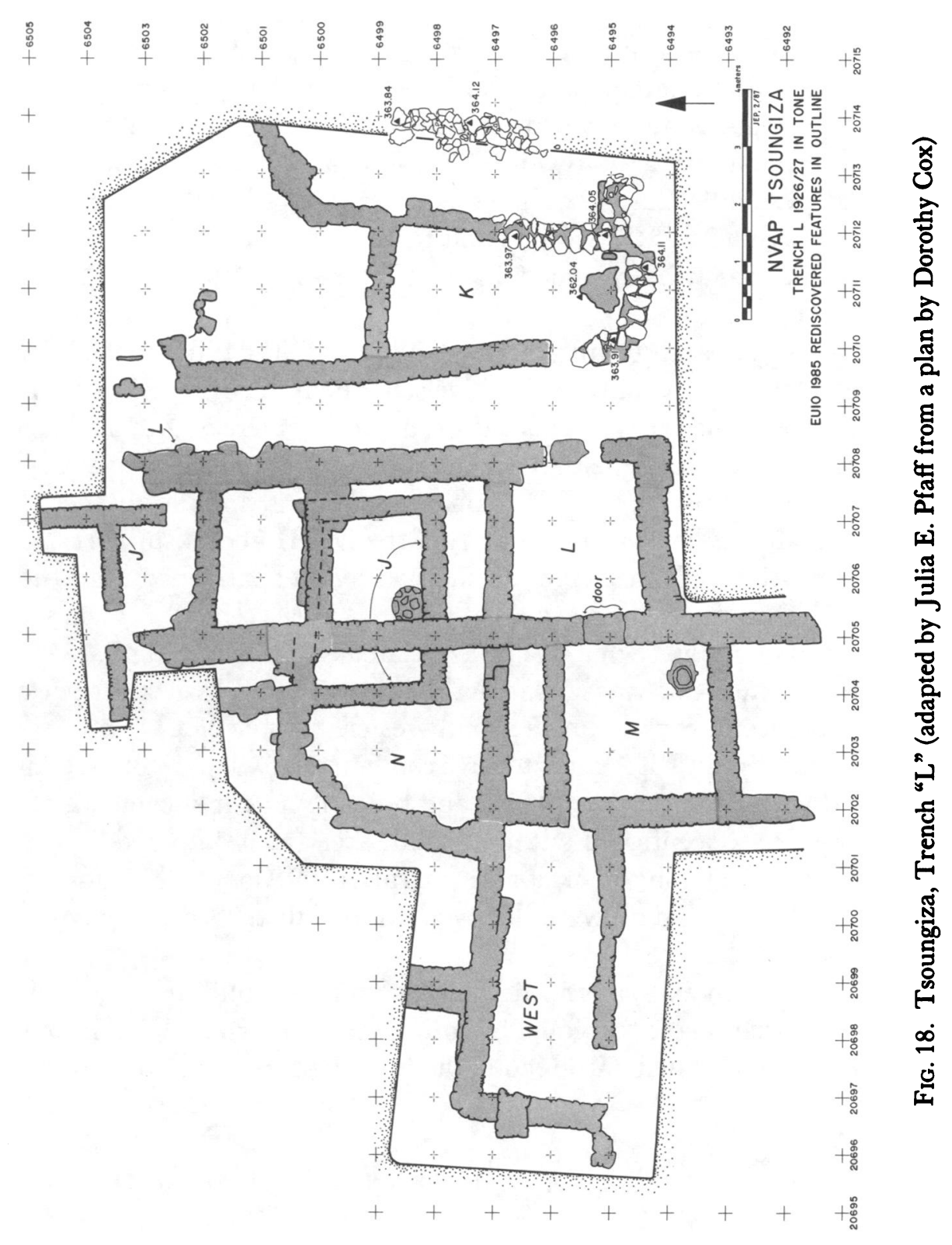




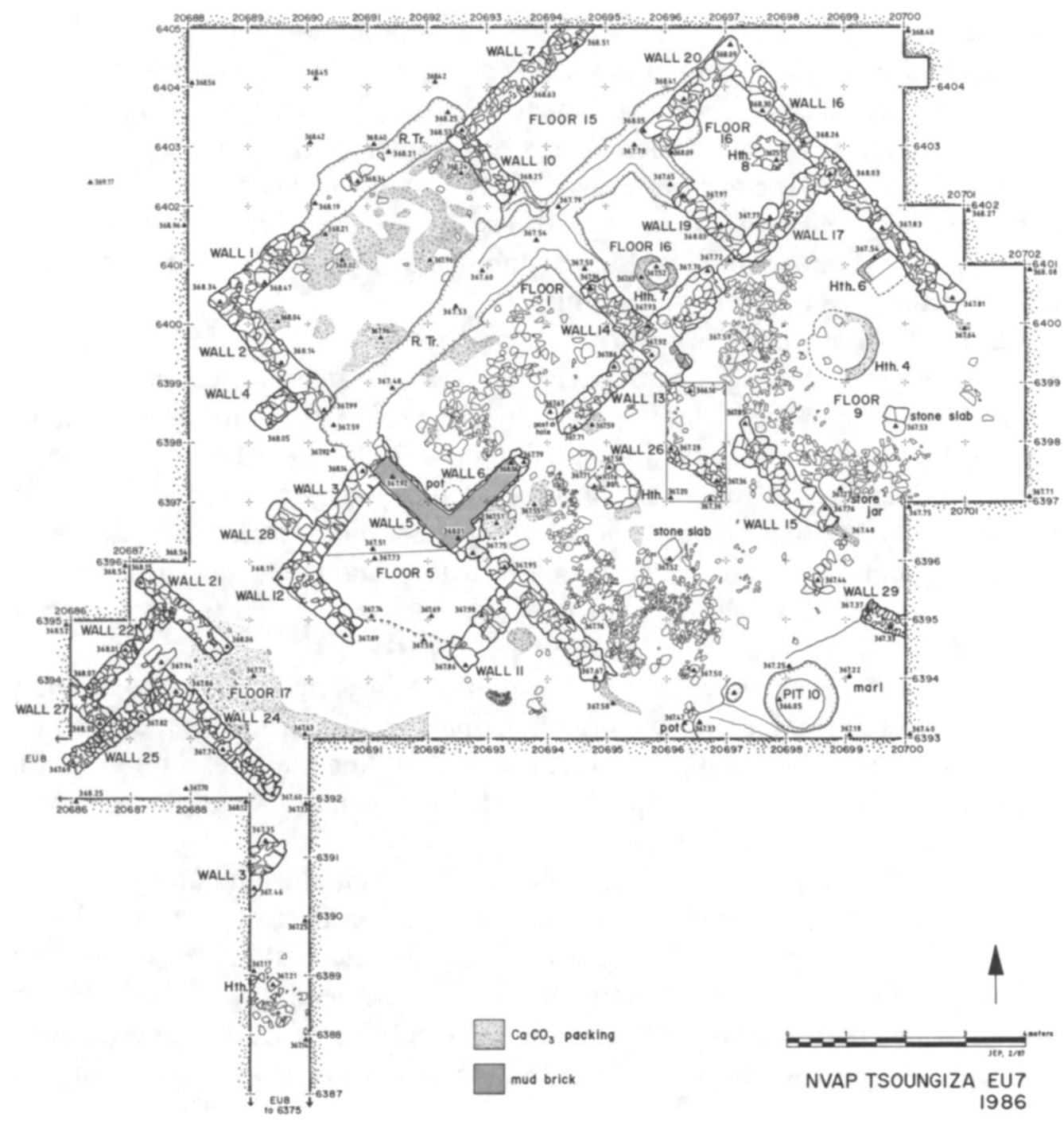

Fig. 19. Tsoungiza, actual-state plan, EU7 (Julia E. Pfaff)

probably occupied in early Mycenaean times were explored by Harland in his test trenches " $O$ " and " $\mathrm{X}$ " (Fig. 12). In "O" were shallow disturbed deposits without evidence of architecture, in " $\mathrm{X}$ " some walls, beneath LH III buildings. We have not been able to locate either trench precisely, since both lay outside the area purchased for excavation; indications of surface remains and of depressions in the land surface, however, suggest their location.

LH I remains are best preserved in EU7, where at the west a freestanding rectangular structure was first built (Pl. 93:c). ${ }^{11}$ At least two annexes were built along its southwest

${ }^{111}$ We follow P. Darcque ("Pour l'abandon du terme 'megaron'," in Treuill and Darcque [footnote 95 above]) in eschewing the term "megaron" for describing Mycenaean buildings with rectangular plans. 
side (Fig. 19) and also probably a rear room, the floor level of which was higher than the other interior rooms. The building has a remarkably formal plan, rectangular with a strong central axis. On this axis in the main room a stone slab supported a central post; a circular stone-built hearth lay behind it, and a central doorway led into the main back room. Along the southwestern side of the main room was a cobblestone paving with smaller hearths set into it. From a deposit in the northern corner of the main room came a cache of unpainted vessels (two cooking pots, two drinking vessels, two jugs, a large goblet, and a ladle; Pl. 95:a), and in the room behind was located another cooking pot. ${ }^{112}$ In contrast, numerous fine painted ceramics were found in the annex. ${ }^{113}$

Early in LH I the structure was burned. Soon after, still within LH I, a new building of the same plan as the original was built to the northeast. ${ }^{114}$ Its southwestern wall was built over the northeast wall of the burnt building (Fig. 19). Like its predecessor this new building has several phases, as indicated by several reorganizations of the interior room(s) and the addition of a back room. It was also outfitted similarly. On the axis of the building was a stone slab, probably a base for a post, and a large, clay-covered circular hearth. Present also is a stone paving along the west side of the main room. Originally a door led from the outer main room into an interior one; later the door was blocked up and the interior room was divided into two smaller ones.

The two buildings are remarkably similar in layout, organization and furnishings. Preliminary analysis of the artifactual and organic remains of the earlier one suggests a domestic, non-specialized function. Nothing from the later building indicates a different function, and its plan and construction over and adjacent to the remains of the earlier one permit the conclusion that it was an immediate replacement for it.

In his trench "L" north of the crown of the hill (Fig. 12), Harland uncovered a complex of structures of Early Mycenaean date, which he argued reflect two phases of habitation, the first of LH I (Buildings K and L, Fig. 18) and the second of LH II (K, L, M, N, and the West Building). ${ }^{115}$ Although no associated finds are preserved, Harland's observations are generally confirmed by results of our excavation in the adjacent EU10, where a substantial LH IIA deposit was uncovered in conjunction with poorly preserved remains of a building

${ }^{112}$ Reported in J. G. Wright, "Excavations at Tsoungiza (Archaia Nemea) 1981," Hesperia 51, 1982, pp. 375-392 and J. B. Rutter, "A Ceramic Definition of Late Helladic I from Tsoungiza," Hydra 6, 1989, pp. 1-19.

${ }^{113}$ NVAP Inv. nos. 1104-2-1 (four-handled jar), 1155-2-1 (juglet or alabaston); 1155-2-2 (goblet); 1155-2-3 (miniature kantharos); 1165-2-1 (?miniature jar); 1173-2-1 (teacup); 1173-2-2 (alabastron); 1181-2-1 (krater); 1181-2-2 (dipper); all published in Rutter, op. cit., cat. nos. 1-4, 6, 10-11, 13, 16.

${ }^{114}$ As reported in Wright ([footnote 112 above] p. 384), the excavation of 1981 discovered indications of a second, post-destruction phase in the area of the western building, including 1) a stone-built platform with a surface plastered with calcium carbonate (E20696.5-20697.5, N6397) and 2) a slab and associated goblet base at E20694, N6397. Subsequent excavations uncovered the subsidiary rooms of the original western building (Fig. 17), the new building to the east, and evidence of many robbed-out walls belonging to both structures. The material from the founding of the East building (1276-2-1, 1276-2-3, 1277-2-1, 1172-2-1) is all LH I. This building was abandoned by the LH IIA period, as certified by a pit of that date cut into its remains (cut through floor 6, Pit 6 with 1193-2-1, 1193-2-2, 1193-2-3).

${ }^{115}$ Harland. House K is Harland's "House of the Arrowhead Maker". 
that lay 10 meters east of those of Harland's Trench L (Fig. 20, Pl. 95:b). ${ }^{116}$ Here at the north there seems to have been a much denser complex of structures during LH II than in the preceding period, although it is worth emphasizing that the buildings uncovered by Harland $(K$, $\mathrm{L}, \mathrm{M}, \mathrm{N}$, and the West Building) each have several phases of occupation and are not all structurally independent of one another (for example, $\mathrm{M}$ is a two-room extension of Building $\mathrm{L}$ ).

In EU2 to the south, a substantial LH IIB floor deposit was recovered. The architecture containing this deposit is extremely poorly preserved; only the northwestern and southeastern walls (Fig. 21, walls 3 and 6) are certainly of that date. The floor deposit consists of plain and decorated vessels, including numerous examples of common shapes for drinking such as conical cups, teacups, and painted (including Ephyraean) and unpainted goblets (Pl. 95:c). There are also squat and piriform jars and a large askos (Pl. 95:d), but virtually no cooking vessels, all suggesting something other than a normal domestic deposit. A large inverted pithos neck was set in the probable western corner of the room, while scattered across the floor were a variety of objects including a large piece of chert, groundstone tools, lead and bronze fragments, and faïence beads. ${ }^{117}$ These Early Mycenaean remains

${ }^{116}$ Rutter has identified four phases overall between the earliest resettlement at the site and levels dating to $\mathrm{LH}$ IIB/IIIA 1; these are two probable phases of very late $\mathrm{MH}$ and one each of LH I and LH IIA. The major restorable vessels of LH IIA date from EU10 are 1759-2-2 (piriform jar with double axe), 1774-2-2 (stemmed cup with blotchy stipple), and 1776-2-1 (Vapheio cup with foliate band). In addition there are a number of unpainted vessels and decorated fragments: 1703-2-2, 1703-2-3, 1764-2-1, $1767-2-1, \quad 1767-2-3, \quad 1774-2-1, \quad 1774-2-3, \quad 1775-2-1$, $1791-2-1$.

${ }^{117}$ Only a small portion of the ceramic assemblage from this floor is illustrated in Plate 95:c, d; most of it comes from SU's 215, 223, 225, 304, 307, 308, and 318. A stippled teacup from this deposit $(308-2-7)$ is stylistically
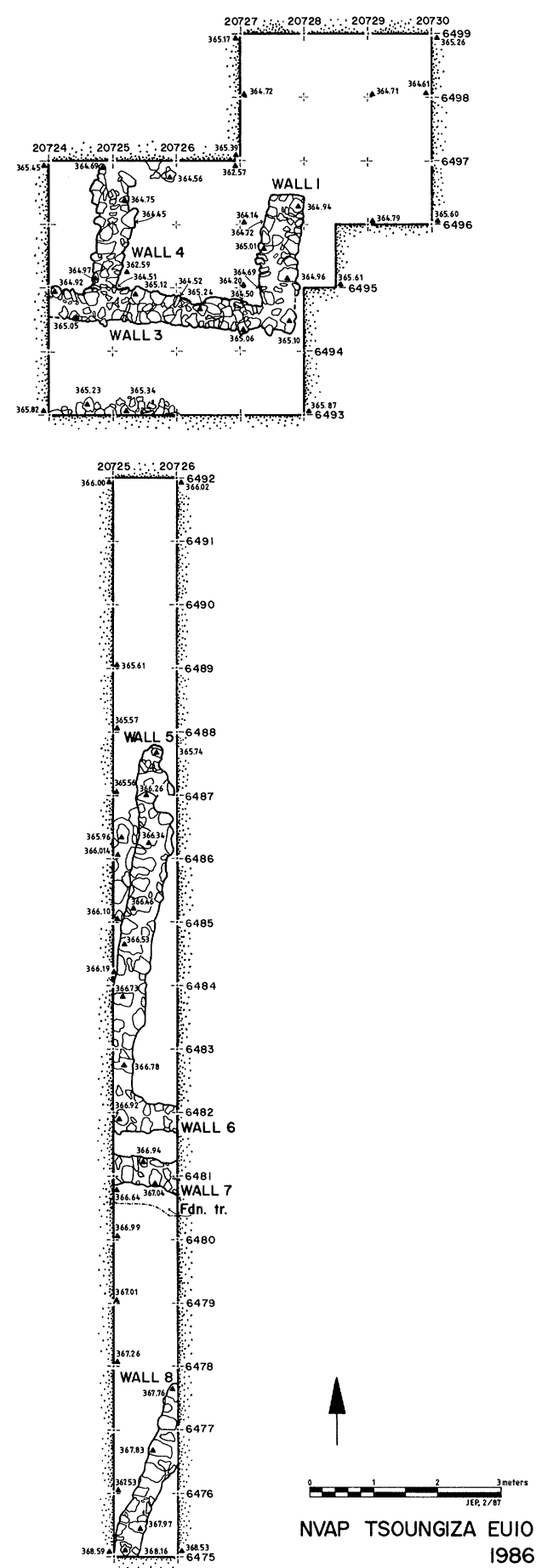

Fig. 20. Tsoungiza, actual-state plan, EU10, northern section (Julia E. Pfaff) 


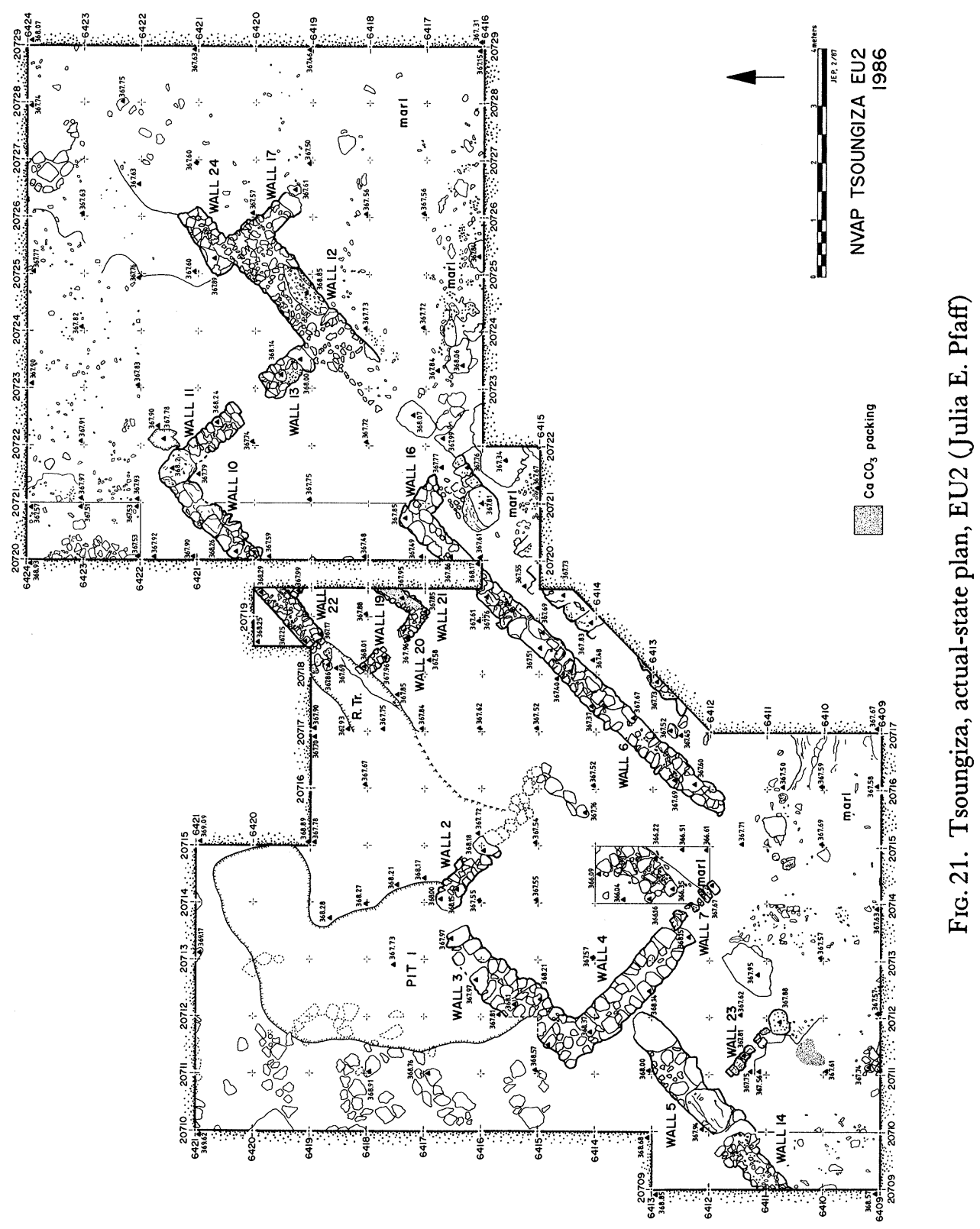


may be part of the area of settlement to the southwest in EU7, a mere 20 meters distant. To the east, north, and west no traces of LH IIB settlement were discovered. ${ }^{118}$

At this stage of analysis it is difficult to evaluate the form of this Early Mycenaean community and how it changed over time. On the one hand, there is no trace of settlement of this period on the hilltop, and no structure stands out as dominant. Instead the site appears to have had at least two clusters of buildings, one at the northern and one at the southeastern side of the hilltop. All evidence presently at our disposal is consistent with a hypothetical reconstruction of LH II Tsoungiza as a small hamlet consisting of several families cooperating together on an egalitarian and subsistence basis. ${ }^{119}$ On the other hand, the growth in the size of the structures in EU7 and Trench L, notably through the addition of rooms, suggests accommodation to increased needs for storage, population growth, or both. Preliminary analysis of the artifacts allows some descriptive observations. The ceramic assemblages from EU7 and EU2 are quite different, the former containing obvious material for cooking and storage, the latter apparently specialized for drinking. In EU10 to the north (and also in Harland's Trench L) the frequency of obsidian hollow points and chert tools contrasts sharply with their near absence in the southern trenches. By LH IIA the settlers on Tsoungiza had perhaps become dependent on the production centers of the Argolid, since the ceramics are indistinguishable from those at Mycenae that are supposed to be from mainstream production centers. Other indications of exchange are found in the chipped stone assemblage, where a ready-worked, creamy chert blade type appears at Tsoungiza. ${ }^{120}$

Although no closed deposit of LH IIIA:1 material has been found, the presence of vessels stylistically assignable to LH IIIA:1 in the otherwise entirely LH IIB floor deposit just discussed, the discovery of one intact LH IIIA:1 vessel from EU7 (NVAP inv. no. 1167-2-1) and the early character of a LH IIIA:2 deposit (discussed below) argue for the continuity of settlement at this time.

An important large deposit of pottery was recovered in EU9 from an apparently artificial cut made into the east side of the hill. ${ }^{121}$ No architecture could be associated with this

LH IIIA:1, but its presence among the otherwise LH IIB material suggests that such stylistic gauges may be less than precise. We thank Dr. Penelope Mountjoy for her opinion of this material, although the view maintained here is ours.

${ }^{118}$ To the east and north of EU2 the marl is found at 20 to $30 \mathrm{~cm}$. below ground surface; we tested in both areas (east extension of EU2, EU11). Resistivity testing conducted by Carl Heron indicated that only bedrock would be found in this area.

${ }^{119}$ J. C. Wright, "An Early Mycenaean Hamlet on Tsoungiza at Ancient Nemea," in Treuill and Darcque (footnote 95 above).

${ }^{120}$ We thank R. Torrence for this interpretation of the blades; most were found by Harland and no longer have a precise context, although there is no doubt that they were found in the Early Mycenaean levels of Trench L.

${ }^{121}$ This deposit is being studied for publication by Mr. Patrick Thomas, who provided the description given here. The deposit contains relatively little patterned pottery, especially when compared to the LH IIIA:1 deposit from the Atreus Bothros at Mycenae (E. French, "Late Helladic IIIA2 Pottery from Mycenae," BSA 60,1965 , pp. 159-202), and the range of shapes is much more limited. In the lower strata, net and scale are the dominant patterns on closed shapes and curved-stem spiral and stipple on the open shapes. Patterned kylikes with the familiar linear stems are not common in these levels; stemmed bowls and goblets appear to be the most prevalent large, open, patterned shapes. In the upper strata, the familiar LH IIIA:2 kylix is present, 
deposit, but it was found lying on a relatively flat surface cut into the bedrock, and in the lowest strata the sherds were of small size and freshly broken. The deposit, which was sealed by strata dating to the LH IIIB period, has yielded more than thirty complete or near-complete profiles, as well as large fragments from many other vessels. The date of the deposit is somewhat problematic and complicated by the possibility that it itself is stratified. A preliminary study of the pottery suggests that the deposit as a whole extends from the end of the LH IIIA:1 period into LH IIIA:2 (early), a poorly understood phase in the development of Mycenaean pottery. If the assigned date is correct, this deposit will help clarify one of the major gaps in the Mycenaean settlement sequence. ${ }^{122}$

The EU9 deposit includes much unpainted pottery, primarily fine wares, although cooking and coarse wares are also well represented. Kylikes are the most abundant shape, with the angular kylix more prevalent than the rounded variety. Shallow angular basins of varying size are also found, in addition to cups and handleless conical cups. Many fragments from jugs, amphoras, and hydrias are also present. Cooking and coarse wares have been noted in lesser quantities: these include tripods and pots, coarse basins, various kinds of coarse jars, and pithoi.

The most notable find from this deposit was a terracotta figure of which only the lower two-thirds was recovered (Pl. 95:e). It is related to the "Lady of Phylakopi" type, although the execution and decoration are cruder. ${ }^{123}$ The presence of this figurine at a small site such as Tsoungiza is surprising, since all previously reported figures of this sort were found either in palatial contexts or large centers such as Phylakopi. The Tsoungiza figure is the earliest securely datable example of this variety, confirming the suggestion of Elizabeth French that this terracotta figure type began in LH IIIA. ${ }^{124}$ Several other small figurines were recovered from this deposit, most notably two examples of the rare "Breadmaker" type (Pl. 95:f). ${ }^{125}$

The interpretation of this deposit is difficult. Were it not for the terracotta figure, probably no cultic significance would be supposed, ${ }^{126}$ for there are no obvious cultic implements

although not in great quantity. Small, patterned stirrup jars also become more common. Curiously, the two most common LH IIIA:2 patterns, the Mycenaean III Flower (Furumark Motif 18) and the Whorlshell (FM 23), are scarcely represented, the Flower appearing only on the shoulder of the stirrup jar, and the Whorlshell not at all. The lack of these patterns suggests that the deposit terminates before the LH IIIA:2 (late) period. Various systems of monochrome decoration, however, are the most common form of painted decoration. Monochrome kylikes and stemmed bowls, which are painted solidly inside and out, occur most frequently, but there are substantial numbers of kylikes and stemmed bowls which are painted solidly on the inside, with the outside left plain, or with only a thin band at the lip. The latter system of decoration may represent a continuation of the mono-in goblets characteristic of the LH IIB period. Much less frequent are stemmed bowls which are solidly painted on the outside and plain on the inside.

${ }^{122}$ French, op. cit., pp. 193-197; French, p. 215.

${ }^{123}$ French.

${ }^{124}$ French, p. 215.

${ }^{125}$ C. W. Blegen, "A Mycenaean Breadmaker," ASAtene, n.s. 8-10, 1946-1948, pp. 13-16; E. French, "The Development of Mycenaean Terracotta Figurines," BSA 66, 1971 (pp. 101-187), p. 173.

${ }^{126} \mathrm{Dr}$. Paul Halstead has remarked, however, that his preliminary sort through the faunal material from the deposit suggests its special nature (personal communication); in general on the interpretation of figurines 
or vessels, only pottery of ordinary domestic nature. If, as was suggested above, the deposit is stratified, a careful examination of the pottery from the level in which the figure was found may provide a better insight into the circumstances of its disposal. The figure itself is partially burned, as are a few of the relatively complete patterned and plain fine-ware vessels so far mended. Further study should indicate whether these vessels and the figure were deposited at the same time, perhaps as a result of the same event.

In EU2 (SU's 209 and 228), a large deposit of early LH IIIB:1 pottery was discovered in a rubbish pit west of a long building of the same date (Figs. 15 and 21, Pit 1). ${ }^{127}$ The building has only been preliminarily studied, but it is clear that it was laid into the remains of the LH II building in the western part of EU2. It is oriented northeast to southwest and was at least 15 meters long, with a courtyard to the north. The pit possibly contained the domestic refuse of the household, since many animal bones and some ground-stone tool fragments were found as well. Although fragmentary and worn, the deposit is significant for its size (more than 20,000 sherds), its range of shapes and patterns, and its exceptional purity, with no later intrusions, and only very small quantities of earlier pottery. It seems, in fact, to contain a nearly complete record of the ceramic assemblage in use at Tsoungiza during this period. As with all our units, all the sherds have been saved, making it a particularly good source for comparative material for other deposits of this date. Stemmed and deep bowls are the most common decorated shapes, but kylikes, kraters, and other open shapes are well represented, while a relatively small number of closed shapes are present. Unpainted pottery, however, forms the bulk of the deposit, with fine cooking and coarse wares all abundantly represented. A detailed examination of the deposit suggests that all the material belongs to the early part of the LH IIIB:1 period, with some of the pottery exhibiting "holdover" LH IIIA:2 characteristics. Two other ceramic dumps have been excavated in the eastern third of EU8. LH III architectural remains are widely distributed over the site (Fig. 13: EU8, EU3, 1979 trenches, EU2, EU9, EU10, and EU5).

The LH IIIB settlement is much more extensive than anticipated at the outset of our investigations. Remains are widely distributed around the hillside and represent diverse activities. The early LH IIIA:2 deposit with its special objects may indicate that the site by that time already had become more important than preserved remains would indicate. In LH IIIB it appears still to have been the primary site of the valley. How then does it compare to its neighbor to the east at Zygouries, where the well-built and planned rooms of the "Potter's Shop" with remains of frescoes, stockpiled vessels, and possible industrial activity suggest a specialized center in close contact with a palace? ${ }^{128}$ If Mycenae controlled areas to

see M. Voigt, Hajji Firuz Tepe, Iran: The Neolithic Settlement, Philadelphia 1983, pp. 186-202, especially her discussion of the functional interpretation of figurines by analysis of use wear and of their means of disposal.

${ }^{127}$ This deposit is being studied for publication by Patrick Thomas, who provided the description given here. Dabney is publishing the architecture and context of the LH III settlement.

${ }^{128}$ For the fresco remains see C. W. Blegen, Zygouries. A Prehistoric Settlement in the Valley of Cleonai, Cambridge, Mass. 1928, p. 37 and pl. III; for the possible use of the "Potter's Shop" as a perfumed-oil workshop see P. M. Thomas, “A Mycenaean Perfumed Oil Workshop at Zygouries?” AJA 92, 1988, p. 254 
its north, as recently suggested in several discussions, ${ }^{129}$ then it is conceivable that centers in the different regions of the Corinthia were used as administrative outposts of the palace, not unlike the situation in Neopalatial Crete. ${ }^{130}$

The latest stratified material on the hill is LH IIIB:2 date and comes from buildings excavated in 1979 and from EU3, EU7, and EU8. ${ }^{131}$ The ceramic contents contain Rosette and Group B deep bowls. ${ }^{132}$ EU9 contains a few sherds of LH IIIC medium band bowls, but not from architectural contexts. Thus it appears that the settlement was abandoned at the end of LH IIIB:2 but that some activity continued into LH IIIC. Thereafter the site was unoccupied, except for possible occasional use for farming, as the presence of rare sherds and tiles of periods concurrent with the use of the Sanctuary of Zeus attests.

\section{Summary}

The excavations on Tsoungiza Hill have been extensive enough through the test trenches and major areas opened up to ascertain that this sketch of the distribution of architectural remains and deposits is probably an approximately correct picture of the phases of occupation. In part this conclusion is corroborated by the results of the survey (pp. 603-617 above), which show a corresponding pattern of occupation throughout the survey area. This is a local pattern of periodic habitation (during EN/early MN, FN through mid-EH II, part of EH III, late MH III-LH IIIB:2) punctuated by abandonment (during most of MN and LN, late EH II-early EH III, and most of MH) during which Tsoungiza seems always to have been a focus for settlement. In relation to the larger region of the northeastern Peloponnesos, Tsoungiza was frequently abandoned during times when other settlements flourished, perhaps another sign of the fragility of settlement in the valley.

\section{GONCLUSIONS}

It should by now be clear that all facets of our investigation are closely related. Also evident is that each component of NVAP has much to contribute to the others, and that answers to virtually all questions of regional scope of the kind described in the introduction to this paper not only can profit from but even demand the acquisition and integration of information from all aspects of the project. For example, data from survey, however valuable and

(abstract); a recent study by I. M. Shear (“The Panagia Houses at Mycenae and the 'Potter's Shop' at Zygou-

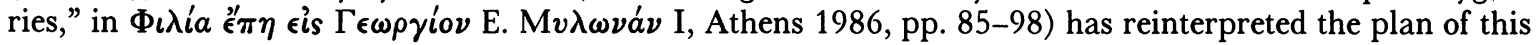
building.

${ }^{129}$ Dickinson; E. Vermeule, "Baby Aigisthos and the Bronze Age," PCPS 213, 1987 (pp. 121-152), p. 133; Wright et al., "Early Mycenaean Settlement."

${ }^{130}$ Dabney in M. K. Dabney and J. C. Wright, "Mortuary Customs, Palatial Society and State Formation in the Aegean Area: A Comparative Study," in Celebrations of Death and Divinity in the Argolid (ActaAth $4^{\circ}$, 40), R. Hägg and N. Marinatos, edd., Stockholm 1990, pp. 45-47; S. Hood, "The Minoan 'Country House' and Minoan Society," in Minoan Society, O. Krzyszkowska and L. Nixon, edd., Bristol 1983, pp. 129-135.

${ }^{131}$ Footnote 91 above; we thank Ms. Dina Kaza, who excavated this material for the Greek Archaeological Service, for permission to mention it here.

${ }^{132}$ E. S. Sherratt, "Regional Variation in the Pottery of Late Helladic IIIB," BSA 75, 1980 (pp. 175-202), pp. 178-180, 200-201. 
essential, certainly should not be considered in isolation. In the past, extensively excavated sites, such as Tsoungiza and the Sanctuary of Zeus, have figured prominently in the reconstruction of hierarchies of settlement and have served as points of articulation between local and external economic, social, and ideological systems. Certainly survey amplifies the appreciation for the size, nature, and extent of occupation in such places, and utilization of information from both survey and excavation is critical for the reconstruction of comprehensive patterns of land use within areas encompassed by such sites. Frequently, as we hope to have demonstrated in the case of Phlius, survey and excavation can in concert enable us to outline a far more complete picture of activities at a site than would be possible with either technique alone. The sum of the results of survey and geological investigations also promises to be greater than its parts. As we have already observed, it is certainly not a new idea that geomorphological studies enable us to estimate the extent to which present land forms approximate those of the past, and thus to evaluate the degree to which distributional patterns of ancient artifacts may be the creations of non-cultural processes. The promise of reciprocal contributions by survey to Quaternary studies has, perhaps, been less appreciated or explored. For example, we fully expect sometimes to be able to suggest on archaeological grounds a terminus ante quem for the deposition of a soil horizon by examining the dates of the earliest artifacts found on its surface. It will be our emphasis on individual artifacts, rather than sites, that permits such analyses, since in many cases alluvial soils have never served as a focus for permanent settlement.

The final picture that we draw of the history of settlement in the area of the Nemea Valley will not (and should not) depend on data collected by surface survey and excavation alone. In our search for those general processes that have determined the distribution of population and have regulated the allocation of land to various human activities in the past we have recognized that the material culture of the past must be integrated with that of the present through ethnoarchaeological studies of the sort described above (pp. 594-603). Physical remains, oral traditions, and the analysis of written records offer an opportunity to study in well-documented (in some cases "living") contexts the formation, disintegration, and transposition of towns and villages, as well as the material consequences of many different kinds of human behavior and agricultural practices. The ethnoarchaeologist may even, as we have already observed, adopt the very techniques of surface survey to collect artifacts from recently occupied sites. An obsession with the present would, of course, limit our investigations to those types of activities and processes that operate at present, but the rich archaeological record of the past that we have sketched allows us to gain access to a lengthy series of pre-modern case studies which, while less detailed than those described by ethnoarchaeological fieldwork, are more frequent in number and span the millennia since the first establishment of agricultural populations in southern Greece. Within this range of case studies lies the potential both for isolating "timeless" responses of man to his surroundings, those material correlates of economic or social behavior that are truly universal and independent of temporally specific systems, and for exploring the evolution of particular adaptations to local cultural and natural environments. Modern and pre-modern patterns of 
settlement and land use must each be treated as independent case studies. We must not project the present into the past. Rather both must play complementary roles in the formation and testing of hypotheses about the relationship between human behavior and material culture.

In conclusion we turn to a discussion of what is the most striking phenomenon of human behavior recognized in the area of the Nemea Valley, a pattern particularly acute in the main valley of Ancient Nemea itself, namely the periodicity of settlement. Why were the valley and its adjacent areas at times apparently uninhabited (if not totally unexploited)? To what extent have natural and cultural factors determined settlement patterns? In this concluding section we review the evidence from two periods of the past during which, on the basis of our research, density of habitation in the Nemea area appears to have fluctuated markedly, namely the Bronze Age and the modern period. The similarity between patterns of occupation and abandonment at these times raises the possibility that it may be possible to generalize more broadly about factors that have in the past determined settlement densities and the distributions of settlements in the landscape. At the same time the striking difference in the nature of our understanding of Bronze Age and modern life illustrates the problems inherent in such generalization.

\section{Patterns of Settlement and Abandonment in the Bronze Age}

The abandonment of the valley within the Middle Neolithic marks the beginning of the first of several cycles of depopulation in later prehistoric times. In many cases such phases seem to follow after periods of relatively intense land use and settlement, when there is ample evidence that local communities were integrated into regional exchange systems embracing areas well outside the limits of our study area. For example, during the Middle Neolithic the character of patterned urfirnis ceramics at the sites investigated by the survey in the Tretos Pass points to ties with settlements elsewhere in southern Greece. ${ }^{133}$

As evidence from Tsoungiza clearly demonstrates, resettlement of the valley and adjacent areas began at the time of the transition between the Final Neolithic period and the Early Bronze Age, and several other smaller settlements persevered throughout much of the 3rd millennium B.c. At this time when there is considerable evidence for the existence of increasingly complex societies elsewhere in southern Greece, ${ }^{134}$ imports discovered at Tsoungiza and survey sites (e.g. the lead stamp [Pl. 94:e] and pottery from as far away as the Saronic Gulf) suggest that communities in the valley were linked with regional exchange networks. The sequence of Early Bronze Age settlement at Tsoungiza permits us to reconstruct the events leading up to a $\mathrm{MH}$ phase of abandonment in even more detail.

${ }^{133}$ Tsoungiza, however, does not display notably common MN shapes and decorative schemes, although MN linear decorated and urfirnis ceramics are represented. See also the split-leg type of figurine found at Site 702, published in Cherry et al., 1988, and evidence of its wider distribution as presented by L. E. Talalay, "Rethinking the Function of Clay Figurine Legs from Neolithic Greece: An Argument by Analogy," AJA 91, 1987, pp. 161-169 and W. W. Phelps, "Prehistoric Figurines from Corinth," Hesperia 56, 1987 (pp. 233253), pp. 235-238.

${ }^{134}$ Pullen (footnote 103 above); Roberts (footnote 61 above); Hägg and Konsola (footnote 100 above). 
There, an apparent cessation of habitation in the later phases of EH II lasted until the early stages of EH III and seems to presage depopulation during the Middle Bronze Age. Only at Tsoungiza is there evidence for extensive EBA settlement after EH II, but it too was abandoned before the end of this period.

The Middle Bronze Age in southern Greece appears generally to have been a time of reduced numbers of settlements, characterized by a generally lower level of social complexity, although there is plentiful evidence for imported goods. ${ }^{135}$ The pattern in the Nemea area is clear. Neither Tsoungiza nor any other location (including Zygouries to the east) appears to have been inhabited before the late $\mathrm{MH}$ period. ${ }^{136}$ There is no evidence that the populations of $\mathrm{EH}$ settlements contracted into a smaller number of larger centers, a process that has been suggested to explain the reduced number of $\mathrm{MH}$ settlements elsewhere in Greece. ${ }^{137}$

It seems hardly a coincidence that repopulation of the valley at the end of the Middle Bronze Age corresponds so closely with the re-emergence of regional social complexity in the northeastern Peloponnesos. Tsoungiza is again the major settlement in the area and may have been the first to be reoccupied. Still in Early Mycenaean times, small establishments were founded at several other locations dispersed throughout the study area. ${ }^{138}$

Occupation in the valley appears to have been continuous throughout the Late Bronze Age. Tsoungiza remained the largest settlement, while a few smaller communities were dispersed around it. Remarkably, the destructions at Mycenae at the end of LH IIIB also mark a significant moment in the history of settlement at Nemea. The fact that occupation did not continue on any scale into LH IIIC either at Tsoungiza or elsewhere underscores the magnitude of the change that accompanied the deterioration of the Mycenaean palacecentered economy (p. 638 above). ${ }^{139}$ Indeed, the entire history of Mycenaean occupation in the area appears closely bound to the development and collapse of the larger centers of the northeastern Peloponnesos.

In this regard, it is worth emphasizing that Dickinson and others have, in fact, suggested that the Corinthia (and with it the area of Nemea) lay under Mycenae's control

${ }^{135}$ Dickinson (footnote 108 above); J. B. Rutter and C. Zerner, "Early Hellado-Minoan Contacts," in The Minoan Thalassocracy, Myth and Reality (Skrifter Utgivna av Svenska Institutet $i$ Athen 32), R. Hägg and N. Marinatos, edd., Stockholm 1984, pp. 75-83; C. Zerner, "Middle Helladic and Late Helladic Pottery from Lerna," Hydra 2, 1986, pp. 58-73; eadem, "Middle Helladic and Late Helladic Pottery from Lerna: Part II, Shapes," Hydra 4, 1988, pp. 1-10; R. Howell, "The Origins of the Middle Helladic Culture," in Bronze Age Migrations in the Aegean, R. Crossland and A. Birchall, edd., Park Ridge, N.J. 1974, pp. 73-106; G. Nordquist, A Middle Helladic Village. Asine in the Argolid (Boreas 16), Uppsala 1987.

${ }^{136}$ See Rutter.

${ }^{137}$ Wright et al., "Early Mycenaean Settlement."

${ }^{138}$ Wright et al., "Early Mycenaean Settlement."

${ }^{139}$ As recently remarked by several scholars (Sherratt [footnote 132 above] p. 203; J. C. Wright, "Changes in Form and Function of the Palace at Pylos," in Pylos Comes Alive, Industry and Administration in a Mycenaean Palace, G. W. Shelmerdine and T. G. Palaima, edd., New York 1984 [pp. 19-29], p. 29), the end of the Mycenaean palatial system was probably more a long-term process than a collapse. At Tsoungiza the site appears to have declined between LH IIIB:1 and LH IIIB:2, notwithstanding the few pieces of LH IIIC discovered, and this process probably corresponds to the changing economic and political fortunes of the central areas. We thank Rutter for bringing the evidence of this phenomenon at Tsoungiza to our attention. 
during the Late Bronze Age. ${ }^{140}$ External domination would thus explain the absence to the north of Mycenae of any center comparable to it in wealth or power. Indeed, such a reconstruction seems at least plausible. The existence of a road system leading north from Mycenae together with the lack of attention to defenses of all the sites in the Corinthia may point to external control. ${ }^{141}$ Moreover, Emily Vermeule has appropriately remarked on the close correspondence between the situation described in the Iliad and that implied by the legendary links between the elite families of Mycenae and Sikyon: "Mycenae held the valleys northward to Corinth, Sikyon, the Gulf of Corinth, and along its southern Shore toward old Achaia...."142

\section{Patterns of Settlement and Abandonment in the Modern Period at Nemea}

Modern patterns of settlement and land use in the Nemea area exhibit discontinuities no less striking than those of the prehistoric periods. Few finds from the survey can be dated to the periods of Turkish occupation of the northeast Peloponnesos. While this circumstance might partly reflect our currently impoverished knowledge of ceramics produced and used at this time, documentary and ethnohistorical accounts as well as a lack of recognizable imports from outside the area also suggest that habitation was restricted. The growth of substantial population centers in the valley began, in fact, only with Greek Independence.

Traditionally the two major transportation routes in this part of southern Greece have both skirted the main Nemea valley, although settlements there would have had easy access to them. To the west, communications between the western Corinthia (including the territories of the Classical poleis of Sikyon, Phlius, and Stymphalos) and the Argive Plain followed a route through the Xeropotamos Valley over Xenophon's Kelossa Pass; direct routes between Corinth and Argos, on the other hand, ran through the Longopotamos Valley and the Tretos Pass. The formation of the modern state of Greece and of a national Greek economy has had profound consequences for the structure of regional transportation systems. With the construction of the Peloponnesian railroad, ca. 1890, the Kelossa Pass ceased to serve as a major route to Argos, and travel between the Phliasian Plain and Argos was redirected along an east-west corridor through the valley of Ancient Nemea. Access to the markets of Athens and Corinth led to local intensification of agriculture and a remarkable increase in population within the valley.

Ethnohistorical sources show that highland areas of the western Corinthia have played an important role in the repopulation of the Nemea Valley in the years since Greek Independence and that, at least since the period of Turkish domination, the valley has been exploited by pastoralists permanently based far to the west. Holdings of the monastery of Agios Georgios in the plain of Pheneos (Fig. 2), for example, included the Xerokampos Valley and were leased to upland-based shepherds for winter pasturage. It would be foolish,

${ }^{140}$ Dickinson; cf. Thomas' argument (footnote 128 above) that the "Potter's Shop" at Zygouries was a perfume workshop. Would it have been an external production center for the palace at Mycenae?

${ }^{141}$ H. Steffen, ed., Karten von Mykenai, Berlin 1884; G. Mylonas, Mycenae and the Mycenaean Age, Princeton 1966; J. G. Wright, Mycenaean Masonry and Elements of Construction (diss. Bryn Mawr College 1978).

${ }^{142}$ Vermeule (footnote 129 above). 
however, to argue that such close relations between the Nemea area and the uplands necessarily existed before the Turkish and modern periods, for it seems clear that the very existence of large-scale pastoralism and of long-distance transhumance (i.e., practices of the sort that have bound the two areas in recent centuries) are dependent on a developed market economy that permits such agricultural specialization. In antiquity herding was most likely conducted on a much reduced scale, and flocks moved over much smaller distances. ${ }^{143}$

The archaeological examination of pastoralist camps should, however, allow us to recognize patterns of material culture associated with such activities and to build more general models useful for testing hypotheses about the nature of land use in the past, especially at those times when the study area itself does not appear to have been the focus of permanent settlement. The process by which the valley was repopulated at the end of the 19th century, as well as the motivations for resettlement, also provide food for thought. Upland shepherds, already exploiting the valley as a source of seasonal pasturage, settled here permanently to take advantage of the proximity of the location to regional markets at Argos and Corinth. The establishment of local production and processing networks, such as that which linked the agricultural communities of Linoi and Heraklion to the mill at Chani Anesti provided for export of surplus from the valley to major areas of early modern Greece.

\section{Summary}

The fortunes of the Nemea Valley seem at most times in the past to reflect the complexity of the political economy of the northeast Peloponnesos. Both in the Bronze Age and in the past few centuries, extensive settlement has been the rule only at times when developed regional political economies have embraced this region. The motivations for settlement in modern times are clear. Opportunities for the formation of capital have encouraged intensification of agricultural production beyond subsistence levels. To accept that similar causes were responsible for the similar patterns of settlement and abandonment we have recognized in prehistoric times, however, would be methodologically unsound; for, in so doing, we would fall victims to the fallacy of equifinality, to the assumption that equivalent responses in material culture can be produced by only a single set of social circumstances. Ethnographically documented explanations for the modern period cannot be uncritically projected into the past to provide ready-made explanations for archaeologically documented patterns in periods during which very different regional political and economic organizations may have obtained.

But what, then, was the stimulus for settlement in the Nemea valley during the Bronze Age, when the very existence of any market economy is in doubt? Changes in technology and agricultural economy from the Late Neolithic to the Early Bronze Age may have facilitated a more successful exploitation of the land than previously. ${ }^{144}$ During the Late Helladic period

${ }^{143}$ J. F. Cherry, "Pastoralism and the Role of Animals in the Pre- and Protohistoric Economies of the Aegean," in Pastoral Economies in Classical Antiquity (Cambridge Philosophical Society, Suppl. Vol. 14), C. R. Whittaker, ed., Cambridge 1988, pp. 6-34.

${ }^{144}$ P. Halstead, “Traditional and Ancient Rural Economy in Mediterranean Europe: Plus ça change?” JHS 107, 1987, pp. 77-87. 
the deliberate desire of external areas to create a surplus of produce by encouraging agricultural production in the valley might partly explain the stability of Mycenaean settlement. The initial settlement during the late Middle Helladic period, however, certainly appears to have been promoted by other, more general, circumstances, perhaps connected with the overall increase in economic activity in the Aegean at this time. These hypotheses define important research objectives that focus on the important question of whether in pre-modern times there was production beyond subsistence within the study area.

Whether or not Nemea was directly controlled by external centers during the Bronze Age, the fact that times of considerable settlement in the area coincided with periods of complex social, economic, and political systems in the Argolid and the Corinthia shows that the fortunes of settlement have been dependent on circumstances external to the valley. Social concerns may have played a major role. For example, small settlements like Tsoungiza probably depended upon exchange of marriage partners to sustain their populations. The very survival of the community may have depended upon membership in regional social systems. This may explain how settlement in the area could have been viable at times in the past, in particular during the Middle Neolithic, when it would be difficult to argue that opportunities for profit making in regional market economies were a motivation for expanded settlement or more intense land use.

It is already clear, however, that the specific environment of the Nemea area is likely to have itself played an important role in determining the past population trends and settlement patterns. Our own studies confirm the results of other geomorphological investigations in the northeast Peloponnesos, which indicate that for the most part the Holocene landscape has been remarkably stable; ${ }^{145}$ there is little evidence that the valley has been subject to catastrophic environmental changes that would have inhibited settlement. The natural landscape appears to have been significantly altered only within the later Neolithic or Early Bronze Age by extensive erosion, perhaps, at least in part, precipitated by cultural activities such as deforestation and overgrazing.

Nonetheless, there remain micro-environmental factors that may partly account for the radical changes in land use that have followed on the collapse of complex regional systems. We know that in early modern times it has been and continues to be necessary to drain the main valley of Nemea by clearing natural drainage channels; previously much of the land had become swampy (and possibly malarial). Likewise, it is clear from geomorphological investigations that similar conditions were present at times in antiquity. ${ }^{146}$ It is likely that after a period of abandonment the re-establishment of a successful agricultural system on the valley floor required considerable investment in manpower to recreate suitable drainage for agriculture in the valley; such seems to have been the case during the Early Christian

${ }^{145}$ T. H. Van Andel, G. N. Runnels, and K. O. Pope, "Five Thousand Years of Land Use and Abuse in the Southern Argolid, Greece," Hesperia 55, 1986, pp. 103-128; Van Andel and Runnels (footnote 13 above); E. Finke, Landscape Evolution of the Argive Plain, Greece: Paleoecology, Holocene Depositional History, and Coastline Change (diss. Stanford University 1988).

${ }^{146}$ Swamps are noted on the present geological maps of the area, and we have inspected and cored them in the Kleonai, Nemea, and Phliasian valleys, and in the basin of Stymphalos. The questions posed here regarding the viability of settlement are equally applicable for these areas, all of which, including the higher plain of Pheneos, supported Classical-period poleis. 
and Byzantine periods, to judge from evidence from the Sanctuary. ${ }^{147}$ These were periods of relatively high population throughout the valley; during periods of smaller and dispersed population, settlers probably could not muster the strength necessary for such an activity, and their settlements may have endured only briefly.

Continuing geomorphological investigations in tandem with ethnohistorical research promise to document these natural phenomena more fully. Such environmental limitations, if they played a significant role in the past, provide only partial answers to the question of why the valley never became a major center of population during either the Bronze Age or historical times. Clearly size and, perhaps more important, location, were other factors in this equation, for in all periods for which we have reasonably sufficient information, the neighboring Kleonai and Phlius valleys always outstripped the Nemea Valley in agricultural development and in the emergence of centers of power. Perhaps only after the prior establishment of centers outside the area of the valley of Ancient Nemea have adequate human resources been available to make permanent occupation in the valley possible and attractive. If so, it is perhaps easier to understand why settlements at Nemea have never truly broken the yoke of dependence that has bound them to their neighbors for the past four millennia. The valley's fortunes have, it seems, always reflected those of larger systems around it; its development can only be understood in context of the larger worlds of which it has been a part.

James C. Wright

Bryn Mawr College

Department of Classical and Near Eastern Archaeology

Bryn Mawr, PA 19010

JOHN F. GHERry

Cambridge University

Faculty of Classics

Sidgwick Avenue

Cambridge CB3 9DA, U.K.

Jack L. Davis

University of IllinoIs at Chicago

Department of Classics

Box 4348

Chicago, IL 60680

Eleni Mantzourani

University of Athens

Philosophical School

57 Solonos

GR-106 79 Athens, Greece

Susan B. Sutton

INDIANA UNIVERSITY AT INDIANAPOLIS

Department of Anthropology

425 Agnes St.

Indianapolis, IN 46202

${ }^{147}$ Miller, 1975, p. 155, pl. 37:f. 


\section{APPENDIX: GERAMICS OF THE HISTORIG PERIOD}

\section{(Plates 96 and 97)}

The relative isolation of the area surveyed, as documented by its ceramic remains, has already been mentioned (p. 610 above). This Appendix presents a brief overview of the pottery evidence that supports those statements and coincidentally illustrates the value of surface collections for the study of wider economic issues. ${ }^{148}$ The loss of the precision provided by stratigraphic control and poor preservation cannot be underestimated; it is, however, at least partially offset by the considerable gain in geographic coverage which allows the researcher, viewing the ceramics of an entire region as an entity and freed from the natural distortion caused by the particulars of individual sites, to speak with some authority about local fabrics and over-all patterns of import into an area.

For chronological and fabric classification we have fortunately been able to draw on the published results of extensive excavations at ancient Corinth and Argos, the two major centers between which the study area lies, as well as the largely unpublished finds from the excavations at the Sanctuary of Zeus at Nemea kindly made available to us by Professor Stephen G. Miller. In attempting to differentiate strictly local products, namely those produced in the area surveyed or at near-by local centers like Kleonai, from material originating near by, in the Corinthia and the Argolid, we have encountered several difficulties. Strong stylistic influence exerted by these two dominant centers sometimes resulted in a koine of style and technique throughout the northeastern Peloponnesos, a circumstance that makes it extremely hard to distinguish local manufactures. The situation is further complicated by our imperfect knowledge of the products of Argos itself, of other Argive sites, and especially of the local centers at Phlius and Kleonai, both as yet barely explored. Furthermore, the geological similarity between Nemea and the territories of its neighbors prevents differentiation of fabrics. ${ }^{149}$ Initial study suggests that some fabrics thought prior to the start of the project to be Corinthian or Argive may also have been manufactured in the study region, while in some periods distinct local styles and fabrics can be recognized. The two new kilns that we have identified (p. 609-610 above) prove local production during some periods.

${ }^{148}$ See footnote 56 above for acknowledgment of the help provided by many scholars without whom this report would not be possible. I am especially indebted to Professor Kathleen Slane, who regularly consulted on pottery of the Roman and other periods during the 1984-1987 seasons, and to Thomas Strasser and Effie Athanassopoulou for assistance in the Nemea Museum. This report is based largely on work conducted at Nemea in the summers of 1984-1986. I am grateful to Professors G. Roger Edwards and Slane for their comments on earlier versions of this text.

The prefix "S" distinguishes catalogue numbers of the Survey from those from the excavation on Tsoungiza Hill. Numbers starting with three or fewer digits are from sites (e.g., S 505-2-4 is from Site 505); those with four-digit prefixes starting with 9 were collected from tracts (e.g., S 9556-2-75 is from Area V, Sector 56).

${ }^{149}$ Cf. Biers, 1971, pp. 401-402 on the difficulties of distinguishing the fabric of Phlius from those of Corinth and Argive sites. He and other scholars seem to apply the term "Argive" loosely to products from various centers in the Argive plain. 
The earliest find after the Bronze Age is the conical base of a Protogeometric skyphos or cup of a type common in the Argolid (Fig. 22:a). ${ }^{150}$ Not much later are two vessels apparently from a grave at Phlius: an almost complete painted aryballos of the Early or Middle Geometric period (Fig. 22:c, Pl. 96:a, right), ${ }^{151}$ similar to examples from the Corinthia, and an unpainted handmade "Argive Monochrome" version of the same shape (Fig. 22:b, Pl. 96:a, left). ${ }^{152}$ From the ash altar of Zeus Apesantios on Mt. Phoukas were collected several thousand small fragments, many in a Geometric style of Corinthian character (Fig. 22:d, e). ${ }^{153}$

In the Archaic and subsequent periods the finds are more widely dispersed and show a greater range. The new votive deposit from Phlius (p. 613 above) strengthens the case for local production of pottery and figurines there during the Archaic and Classical periods. Unlike the deposit excavated at Phlius in 1925, in which the majority of the figurine types are male, in the new one all 30 fragments that are well-enough preserved for identification seem to come from seated or standing female types. ${ }^{154}$ Eleven are handmade, either birdfaced heads or lower portions of seated females, and can be dated to the seventh and sixth centuries B.C. (Pl. 96:b). ${ }^{155}$ The remainder, moldmade and mostly flat backed, come from standing female types of the 6th and 5th centuries B.c. ${ }^{156}$ Of the later examples, one (S 9413-2-142, Pl. 96:C) ${ }^{157}$ belongs to a Corinthian mold type which does not occur in contexts dated before the second half of the 5th century B.c., while a head with polos

${ }^{150}$ S 9372-2-8. Painted inside only. Cf. B. Wells, Asine, II, iv, The Protogeometric Period: Catalogue of Pottery and Other Artifacts, Part 3: Results of the Excavations East of the Acropolis 1970-1974, Stockholm 1983, pp. 188, 201-202, 208.

${ }^{151} \mathrm{~S}$ 9413-2-468; the fabric is pale with paint that adheres well; cf. J. N. Coldstream, Greek Geometric Pottery: A Survey of Ten Local Styles and Their Chronology, London 1968, pp. 93-95, pl. 17:b, c; the sequence postulated by P. Lawrence ("Five Grave Groups from the Corinthia," Hesperia 33, 1964 [pp. 89107], pp. 90-91, note 5) may not take account of local variation, especially as the type occurs also in the Argolid.

${ }^{152}$ S 9413-2-476; cf. S. S. Weinberg, Corinth, VII, i, The Geometric and Orientalizing Pottery, Cambridge, Mass. 1943, nos. 16-18, p. 7, 51, p. 15, 66, p. 18, pls. 2, 9, 10; Lawrence (footnote 151 above), M3, pp. 90-91, pl. 17; N. Kourou, "A propos de quelques ateliers de céramique fine, non tourné du type 'Argien Monochrome'," BCH 111, 1987 (pp. 31-51), p. 35.

${ }^{153}$ Fig. 22:d: S 306-2-29, from the wall of a closed shape; Fig. 22:e: S 306-2-23; jar neck, probably Middle Geometric.

${ }^{154}$ For the 1925 deposit, see Biers, 1971. In the new deposit another 31 fragments probably from figurines of the same types include probable chair legs, laps of seated figures, struts, and pieces too worn for certain identification.

${ }^{155}$ S 9413-2-287, S 9413-2-305, S 9413-2-280, S 9413-2-309, S 9413-2-301. Cf. Biers, 1971, nos. 76-82, pp. 418-419. M. Guggisberg ("Terrakotten von Argos. Ein Fundkomplex aus dem Theater," BCH 112, 1988 [pp. 167-234], pp. 170-173) now argues that the production of such figures at Argos begins no earlier than the 6th century B.c.

${ }^{156}$ At least one hollow-backed example has been identified, S 9413-2-288 (not illustrated). Given the longevity and conservatism of coroplastic types, the possibility that some were made somewhat later cannot be excluded.

${ }^{157}$ Cf. A. N. Stillwell, Corinth, XV, ii, The Potters' Quarter: The Terracottas, Princeton 1952, Class X, nos. $8,9,10$, p. 90 , pl. 14, Spes type IIA. 


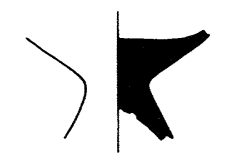

a

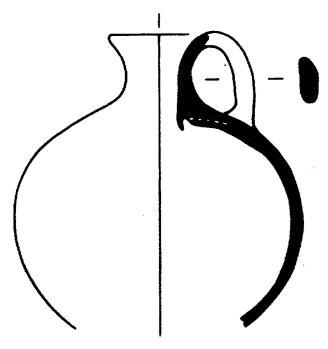

$\mathrm{b}$
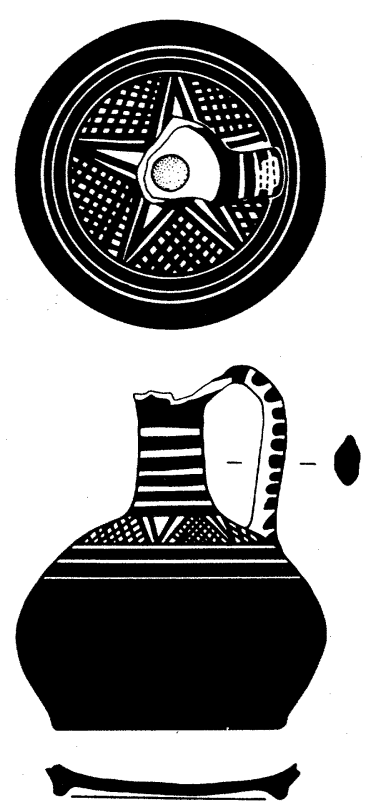

c

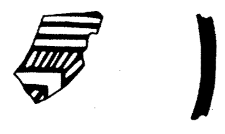

$\mathrm{d}$

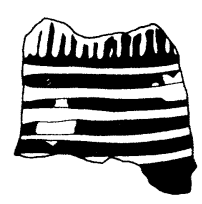

e

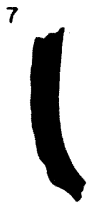

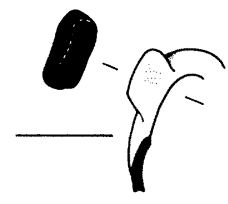

g

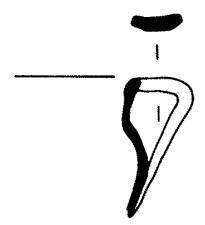

$\mathrm{h}$

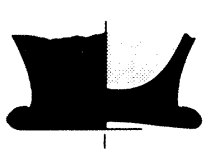

i

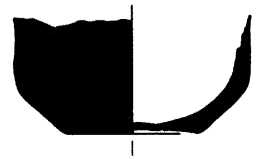

j

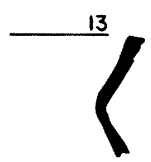

$\mathrm{k}$

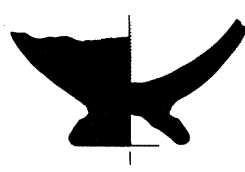

1

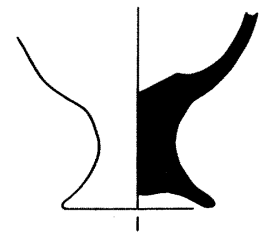

$\mathrm{m}$

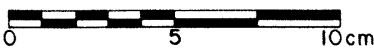

FIG. 22. Survey, ceramics, Geometric: a, S 9372-2-8; b, S 9413-2-476; c, S 9413-2-468; d, S 306-2-29; e, S 306-2-23. Archaic-Classical deposit from Phlius: f, S 9413-2-197; g, S 9413-2-219; h, S 9413-2-224; i, S 9413-2-202; j, S 9413-2-227; k, S 9413-2-270; 1, S 9413-2-211; m, S 9413-2-212 
(S 9413-2-307, Pl. 96:c) ${ }^{158}$ is related to Corinthian types generally found in Classical contexts. Struts applied to the backs of several Archaic molded figurines (Pl. 96:d) ${ }^{159}$ represent a local, quite possibly Phliasian, innovation.

Pottery from this deposit includes fine, painted, and votive pieces, along with a few utilitarian shapes and fabrics. In contrast to the 1925 deposit, not only miniatures but also full-size shapes are well represented. While Corinthian imports occur, much of the pottery seems local and finds close parallels in the 1925 deposit, at the Agamemnoneion at Mycenae, and in the Sanctuary of Zeus at Nemea. Many of the Archaic shapes represented are connected with the drinking and serving of wine, including kraters (Fig. 22:f), ${ }^{160}$ kantharoi (Fig. 22:g, h), ${ }^{161}$ kalathoi (Fig. 22:i), ${ }^{162}$ and oinochoai (Fig. 22:j). ${ }^{163}$ Other fragments (Fig. 22:k, l) ${ }^{164}$ probably come from Classical versions of the cup and krater forms. While the paint used on many pieces is fugitive, many others were probably left plain; examples like the unpainted, semicoarse base of a closed(?) form (Fig. 22:m) ${ }^{165}$ probably represent survivals of the Argive Monochrome tradition and are not easily dated.

Archaic and Classical painted and black-glazed pottery was certainly imported into the region from Corinth and Attica, although small fragments are not always easily distinguished from local and Argive wares. Of the many examples a few warrant special comment in this context. Classical black-glazed fragments seem to belong to a Classical Attic mug that was discolored by burning (Fig. $23: a) ;{ }^{166}$ however, a virtually complete plate from the

${ }^{158}$ Cf. ibid., Class VIII, 54, p. 78, pl. 14; Class X, nos. 1, 2, pp. 88-89, pl. 15, nos. 24, 27, 28, 30, 32, 33, pp. 92-94, pls. 15, 16; Class XI, no. 1, p. 76, pl. 17, and the protomes Class XII, e.g. no. 12, pp. 100-101, pl. 19; on their dating, p. 85.

${ }^{159}$ S $9413-2-300$, S 9413-2-310, S 9413-2-295, S 9413-2-187, S 9413-2-319, S 9413-2-293, S 9413-2-290. Such struts are applied to moldmade figurines of several types from the 1925 deposit and to standing female figurines from the Argive Heraion; Biers, 1971, pp. 419-420 and nos. 86-91, 99, pp. 420-422; C. Waldstein and G. H. Chase, "The Terracotta Figurines," in The Argive Heraeum, II, C. Waldstein, ed., Boston 1905 (pp. 3-44), p. 32, nos. 135 (fig. 56) and 136 (3 examples, none illustrated). The examples from the Heraion may be Phliasian imports. A uniform soft, pale gray fabric which resembles Corinthian is used for all figurines in the new deposit except S 9413-2-143 (not illustrated), which is of a hard, red fabric.

${ }^{160} \mathrm{~S}$ 9413-2-197, interior and exterior covered with brown-to-black paint, with crazing. The kraters seem like those from the Agamemnoneion at Mycenae and the miniatures in the 1925 Phlius deposit: Cook, pp. 41-43, and Biers, 1971, nos. 13 and 14, p. 405, pl. 86.

${ }^{161}$ Fig. 22:g: S 9413-2-219, perhaps originally painted; cf. the elaborated handles in the 1925 deposit, Biers, 1971, no. 46, A-D, p. 414, pl. 89. Fig. 22:h: S 9413-2-224, painted brown in and out; cf. Biers, 1971, nos. 20 and 21, p. 407, pl. 86; S. G. Miller, "Excavations at Nemea, 1980," Hesperia 50, 1981 (pp. 45-67), pp. 64-65, pl. 24:f; and Cook, nos. 4-14, pp. 42-44.

${ }^{162}$ S 9413-2-202; cf. Cook, no. B27, pp. 46-47, fig. 21, nos. B26 and B28, pl. 19 and Miller, op. cit., pp. 64-65, pl. 24:d.

${ }^{163} \mathrm{~S}$ 9413-2-227, perhaps an oinochoe or an open form; red paint outside; interior possibly with white slip, or unglazed. Cf. the angular forms of the cup and bowl from the Agamemnoneion: Cook, nos. B19 and B22, p. 47, fig. 20 and the miniature cups from Phlius: Biers, 1971, no. 29, p. 408, pl. 87.

${ }^{164}$ Fig. 22:k: S 9413-2-270, rim of a small krater or kantharos; thin, crazed brown paint inside and out. Fig. 22:1: S 9413-2-211, base of a small open shape; thin glaze inside and out.

${ }^{165} \mathrm{~S} 9413-2-212$.

${ }^{166}$ S 505-2-4, two non-joining mug fragments with stamped and impressed decoration; soft fabric, mottled reddish yellow and gray; second half of the 5th century B.c. The forms and decoration find close parallels with Attic pieces: B. A. Sparkes and L. Talcott, The Athenian Agora, XII, Black and Plain Pottery of the 6th, 5th, and 4th Centuries B.C., Princeton 1970, nos. 202 and 203, pp. 72-74, fig. 3, and no. 207, fig. 3, pl. 47. 


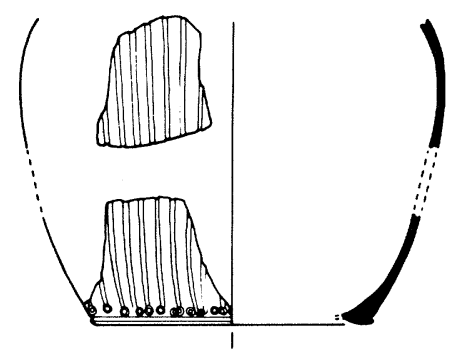

a

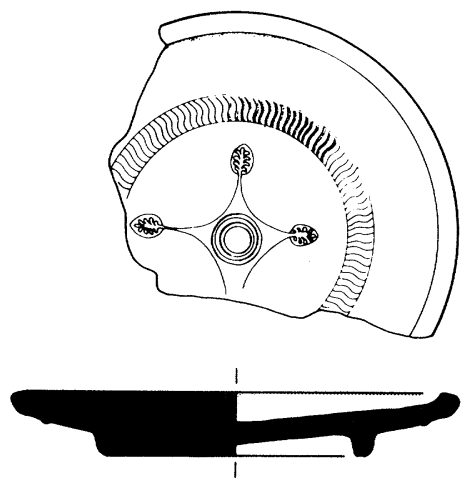

b

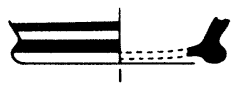

c

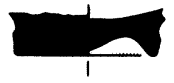

e

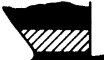

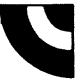

f g

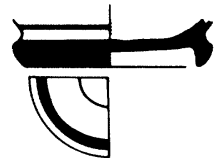

d

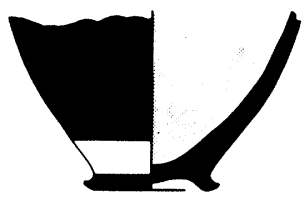

0

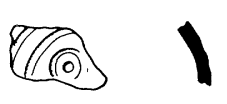

$\mathrm{h}$

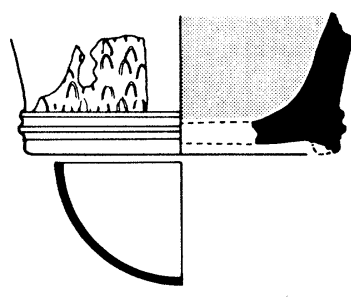

i

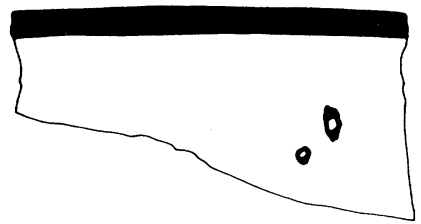

k
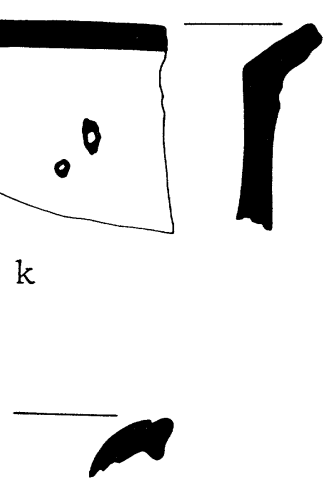

$\mathrm{n}$

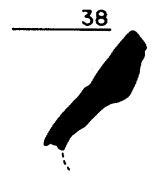

1
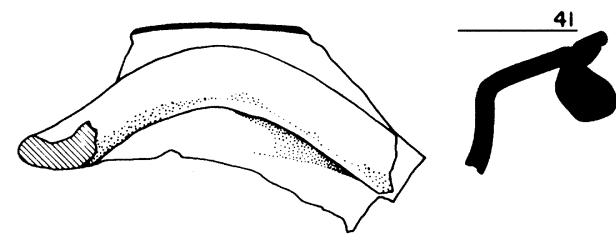

m

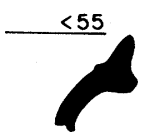

$\mathrm{p}$

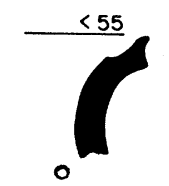

0
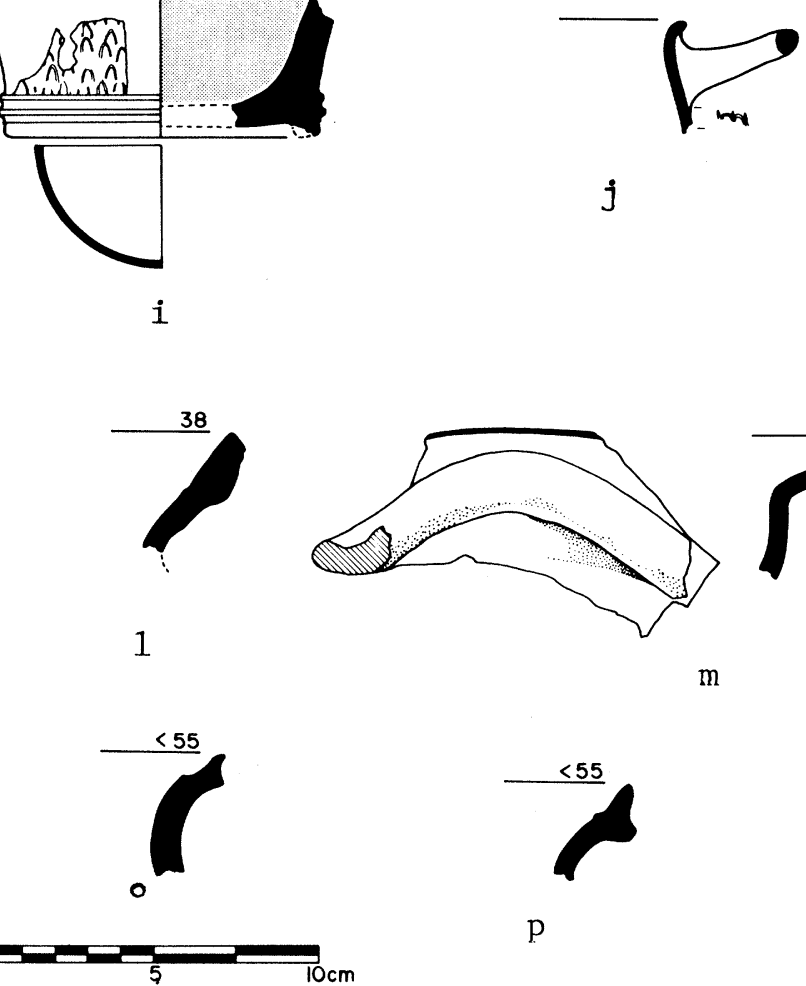

FIg. 23. Survey, ceramics, Classical Attic imports or imitations: a, S 505-2-4; b, S 9413-2-467.

Archaic-Classical Argive imports: c, S 703-2-40; d, S 204-2-592; e, S 9111-2-52; f, S 9413-2-364;

g, S 9413-2-365. Classical-Roman Argive imports: h, S 800-2-10; i, S 9111-2-45; j, S 101-2-37;

k, S 501-2-10; 1, S 701-2-31; m, S 501-2-60; n, S 512-2-587; o, S 9413-2-624; p, S 9443-2-584 


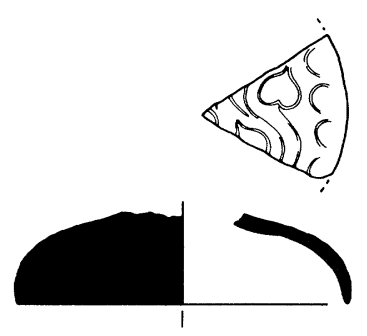

a

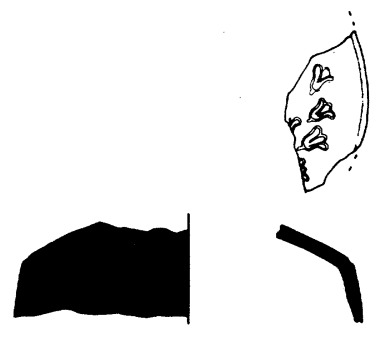

$\mathrm{b}$

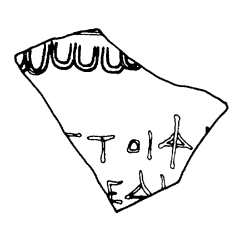

C
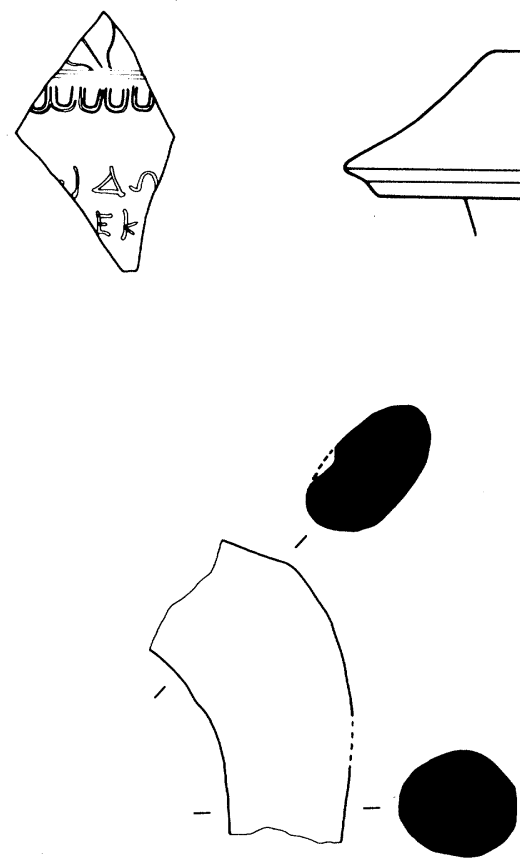

f

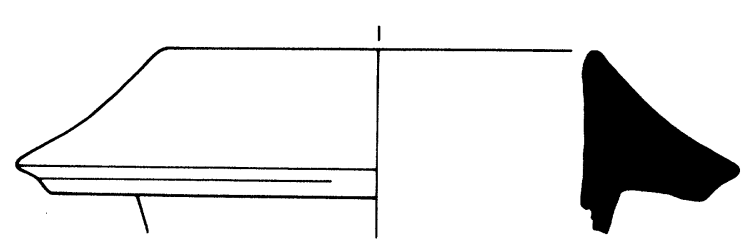

d

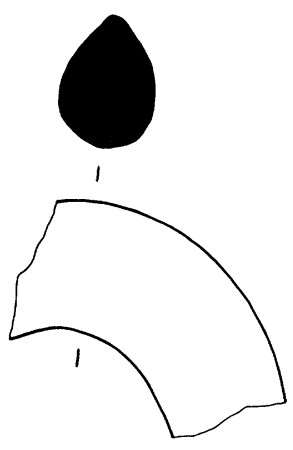

$\mathrm{e}$
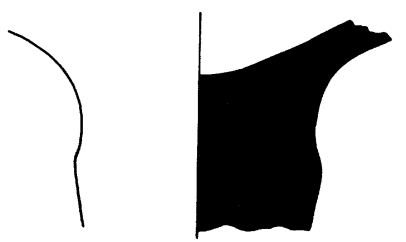

g

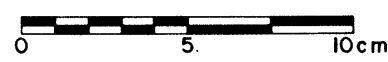

FIg. 24. Survey, ceramics, blister ware: a, S 9388-2-88; b, S 204-2-448; c, S 904-2-1, S 904-2-2. Amphoras: d, S 2-2-50; e, S 304-2-102; f, S 9111-2-13; g, S 101-2-41

disturbed cemetery at Phlius (Fig. 23:b), ${ }^{167}$ close to Attic prototypes in form and decoration but executed in a uniform soft gray fabric similar to the mug, may indicate that local Classical workshops were making very close imitations of Attic ware. Far more common are black-glazed fragments of pale brown local and Argive fabrics like the bases of cups, bowls,

${ }^{167} \mathrm{~S}$ 9413-2-467, from Phlius, plate with impressed palmettes and rouletting, soft gray fabric; 4th century в.c.; cf. Sparkes and Talcott, op. cit., p. 147, fig. 10, pls. 36, 59. 
and plates (Fig. 23:c-g) ${ }^{168}$ datable to the 6th and 5th centuries B.c. Two hard-fired skyphoi covered with lustrous black glaze, one decorated with impressed ovules (Fig. 23:i), ${ }^{169}$ the other with incised or impressed decoration (Fig. 23:j), ${ }^{170}$ are likely to be products of Argos during the 4th century B.c. A Hellenistic moldmade bowl decorated with a Macedonian shield pattern can be added to the small group of this type made in Argos (Fig. 23:h). ${ }^{171}$ Argive krater rims (Fig. 23:k-m) ${ }^{172}$ of the later Classical and Hellenistic periods seem related to a form that appears in both fine and utilitarian wares in the later Hellenistic and Early Roman eras (Fig. 23:n-p). ${ }^{173}$

Although blister ware, a distinctive Classical hard-fired fabric, has been regarded as a Corinthian product, our discoveries may support the view of G. R. Edwards that it was also made elsewhere. ${ }^{174}$ They include squat aryballoi, some with ribbed decoration as at Corinth ${ }^{175}$ but also an example with incised ivy leaves bordered by arcs (Fig. 24:a). ${ }^{176}$ A shoulder fragment, perhaps from an askos, is stamped with lilies (Fig. 24:b, Pl. 97:a). ${ }^{177}$ Finally, two non-joining blond blister-ware fragments from the vertical wall of a large closed shape preserve parts of a two-line inscription incised before firing, bordered above by impressed ovules and incised ivy leaves (Fig. 24:c, Pl. 97:b).

a.

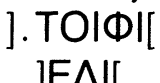

]E $\Delta \mathrm{I}[$ b.

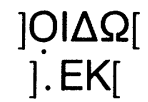

Although the text is too incomplete for restoration, the letter forms suggest a date between the second half of the 4 th century and first half of the 3 rd century B.c. ${ }^{178}$

${ }^{168}$ Fig. 23:c: S 703-2-40. Fig. 23:d: S 204-2-592. Fig. 23:e: S 9111-2-52. From Phlius: Fig. 23:f: S 9413-2-364 and Fig. 23:g: S 9413-2-365.

${ }^{169} \mathrm{~S} 9111-2-45$; distinctive small rings of glaze on the interior, apparently left by the bursting of bubbles in the black-glaze slip, are paralleled on skyphoi from the Agamemnoneion: Cook, no. G7, pp. 59-60.

${ }^{170} \mathrm{~S}$ 101-2-37, with exaggerated horseshoe handles and incised or impressed decoration under black glaze; cf. Cook, pp. 59-60.

${ }^{171} \mathrm{~S}$ 800-2-10. Gf. G. Siebert, Recherches sur les ateliers de bols à relief du Péloponnèse à l'époque hellénistique, Rome 1978, DI.124 and DI.125, p. 39, pl. 20 and M. 99, p. 58, pl. 30; C. M. Edwards, "Corinthian Moldmade Bowls: The 1926 Reservoir," Hesperia 55, 1986 (pp. 389-419), pp. 393-395.

${ }^{172}$ I am indebted to Kathleen Slane for identifying this shape. Fig: 23:k: S 501-2-10, black glaze inside, on rim, and spilled on exterior, late Classical or Hellenistic. Fig. 23:1: S 701-2-31, thin black glaze inside, Hellenistic. Fig. 23:m: $\mathrm{S}$ 501-2-60, brown slip on exterior, Hellenistic(?).

${ }^{173}$ Fig. 23:n: S 512-2-587, thin red glaze; cf. Edwards, no. 705, p. 134, pl. 33; K. S. Wright, "A Tiberian Pottery Deposit from Corinth," Hesperia 49, 1980 (pp. 135-177), no. 104, pp. 156, 160; K. W. Slane, "Two Deposits from the Early Roman Cellar Building, Corinth," Hesperia 55, 1986 (pp. 271-318), no. 15, pp. 280-281. From Phlius, semi-coarse: Fig. 23:o: S 9413-2-624; Fig. 23:p: S 9413-2-584.

${ }^{174}$ Edwards, pp. 144-150 on blister ware, and p. 144, note 3 on the non-Corinthian examples from Nemea. For recent discoveries at Nemea see Miller, 1979 (footnote 51 above), pp. 80 and 92, pls. 23:a, 33:d; Miller, 1980, p. 196, pl. 46:f; Miller, 1982, p. 33, pl. 14:e. Preliminary reports indicate that large amounts of blister ware were discovered in the Aphrodiseion at Argos: G. Daux, "Chronique des fouilles et découvertes archéologiques en Grèce en 1967," BCH 92, 1968 (pp. 711-1136), pp. 1027-1028, 1030, fig. 12. I suspect that the origin of blister ware lies in the Argolido-Corinthian Argive Monochrome tradition with which it shares both the handmade technique and a marked preference for the aryballos shape.

${ }^{175}$ Edwards, pp. 146-148, pls. 35-36, 64.

${ }^{176} \mathrm{~S}$ 9388-2-88.

${ }^{177}$ S 204-2-448; for the shape cf. Edwards, pp. 146-148, pl. 64.

${ }^{178}$ S 904-2-1 and S 904-2-2. Note the non-cursive omega, small floating omicron, and phi with triangular 
As mentioned above (p. 610), fragments of trade amphoras are relatively rare in comparison with other surveys. In the pre-Roman period, jars of Corinthian Type A appear to be the most common type (Fig. 24:d-g). ${ }^{179}$ Much of the other coarse ware used from the Mycenaean to the early Hellenistic period (and later) appears to contain the same mudstone temper characteristic of Corinthian Type A amphoras and other Corinthian coarse wares, ${ }^{180}$ although there is considerable range in the color of the paste. While some finished products were surely imported from Corinth, a good proportion may have been produced locally. Typical are an Archaic louterion base with a stamped band of rosettes alternating with leaves and tongues (Fig. 25:a, Pl. 97:c); ${ }^{181}$ a Classical rim with dipinto $\left.<0\right\}:$ (Fig. 25:b); ${ }^{182}$ a Classical louterion rim (Fig. 25:c) $;^{183}$ a virtually complete wide-mouth pithos rim with tongues impressed on the body (Fig. $25: \mathrm{g}) ;{ }^{184}$ and pithoi decorated with applied straight and wavy bands, often in clay of contrasting color and sometimes with slip of contrasting color (Fig. 25:d, f) ${ }^{185}$ A distinctive group of the latter that is hard fired and alternates between shades of orange red and blue black, often in as many as five layers in the core (Fig. 25:e) ${ }^{186}$ should probably be connected to blister ware and the fabric of Classical

body. Cf. clay labels from the Sanctuary of Demeter at Corinth, incised before firing, tentatively dated by Stroud to the second half of the 4th and first half of the 3rd century B.c. (R. S. Stroud, "The Sanctuary of Demeter and Kore on Acrocorinth," Hesperia 37, 1968 [pp. 299-330], p. 328, pl. 98:h-k; A. H. S. Megaw, "Archaeology in Greece, 1964-65," $A R$ 1964-1965 [pp. 3-31], p. 9, fig. 7) and the papyrus of Timotheos, Persai, where the distinctive triangular phi occurs, dated to the second half of the 4th century B.c. (E. M. Thompson, An Introduction to Greek and Latin Palaeography, Oxford 1912, pp. 105-109, chart pp. 144-145). Other inscriptions incised before firing on Corinthian drinking cups of the later 4th and 3rd centuries B.C. (Edwards, pp. 64-66, pls. 41, 42) use more cursive forms.

${ }^{179}$ Fig. 24:d: S 2-2-50, rim, 4th century B.c.; cf. C. Koehler, "Evidence around the Mediterranean for Corinthian Export of Wine and Oil," in Beneath the Waters of Time: Proceedings of the Ninth Conference on Underwater Archaeology, J. B. Arnold, III, ed., Austin 1978 (pp. 231-239), p. 232, fig. 1:e and p. 236. Fig. 24:e: S 304-2-102, handle, mid-5th to 4th century B.c.; cf. ibid., p. 232, fig. 1:e; C. Koehler, "Corinthian Developments in the Study of Trade in the Fifth Century," Hesperia 50, 1981 (pp. 449-458), pp. 454-455, fig. 1:d. Fig. 24:f: S 9111-2-13, handle, 6th or early 5th century B.c.; cf. Koehler, 1978, p. 232, fig. 1:b and p. 236, and Koehler, 1981, pl. 98:d, e. Fig. 24:g: S 101-2-41, base, 5th to early 4th century B.c.; cf. Koehler, 1978, p. 454, pl. 98:g, h and P. B. Vandiver and C. G. Koehler, "Structure, Processing, Properties, and Style of Corinthian Transport Amphoras," in Technology and Style: Ceramics and Civilization II, The American Ceramic Society, Columbus, Ohio 1986 (pp. 173-215), p. 186, fig. 13.

${ }^{180}$ I. K. Whitbread ("The Characterisation of Argillaceous Inclusions in Ceramic Thin Sections," Archaeometry 28, 1986, pp. 79-88) argues that the temper in Corinthian products is mudstone. Examples from our survey have not yet been examined by a petrologist. Similar temper appears more finely ground in high-fired amphoras of the Byzantine and Frankish periods.

${ }^{181}$ S 400-2-10; cf. M. Iozzo, “Corinthian Basins on High Stands,” Hesperia 56, 1987 (pp. 355-416), p. 393, fig. 4, pls. 74-77.

${ }_{182} \mathrm{~S} 204-2-441$, pink-buff fabric.

${ }^{183} \mathrm{~S}$ 4-2-141; the pendent edge is painted with bands (from the top: black, reserve, red, reserve, black, reserve, red) that show little articulation with the molded forms. Cf. Iozzo (footnote 181 above), pp. 375 and 381 , figs. 2 and 3.

${ }^{184} \mathrm{~S}$ 204-2-172; hard pink fabric.

${ }^{185}$ Fig. 25:d: S 401-2-20, pink paste with gray core, possibly white slipped. Fig. 25:f: S 9398-2-32, light-red paste with applied wave of refined white clay.

${ }^{186} \mathrm{~S} 101-2-21$, applied bands of red clay, white slip covering the body and the applied bands. 


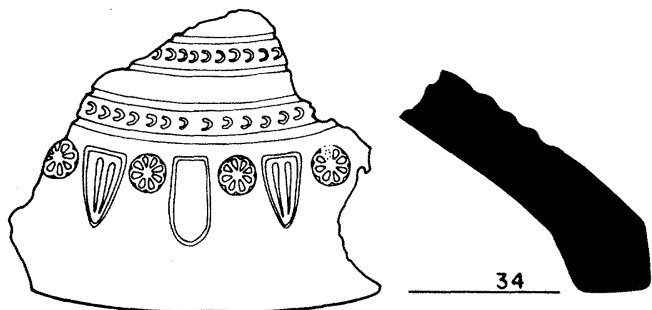

a

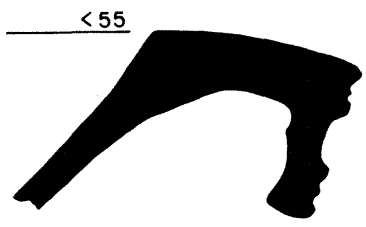

c

64
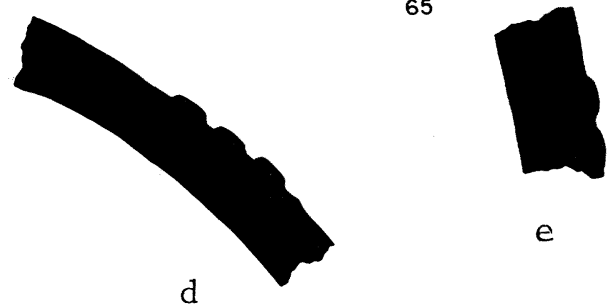
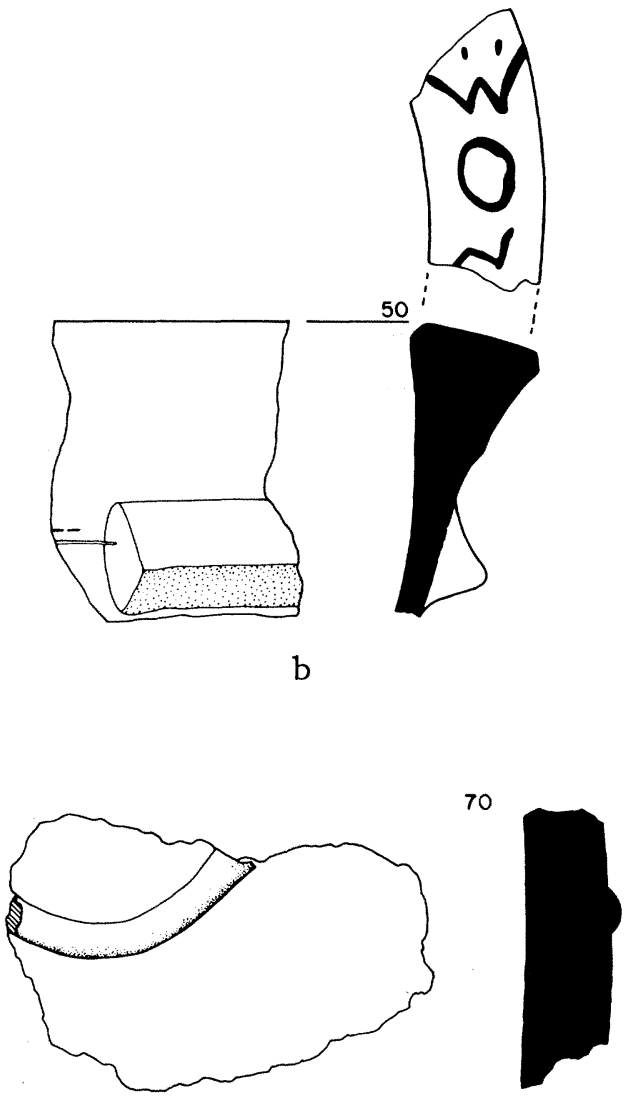

$\mathrm{f}$

82
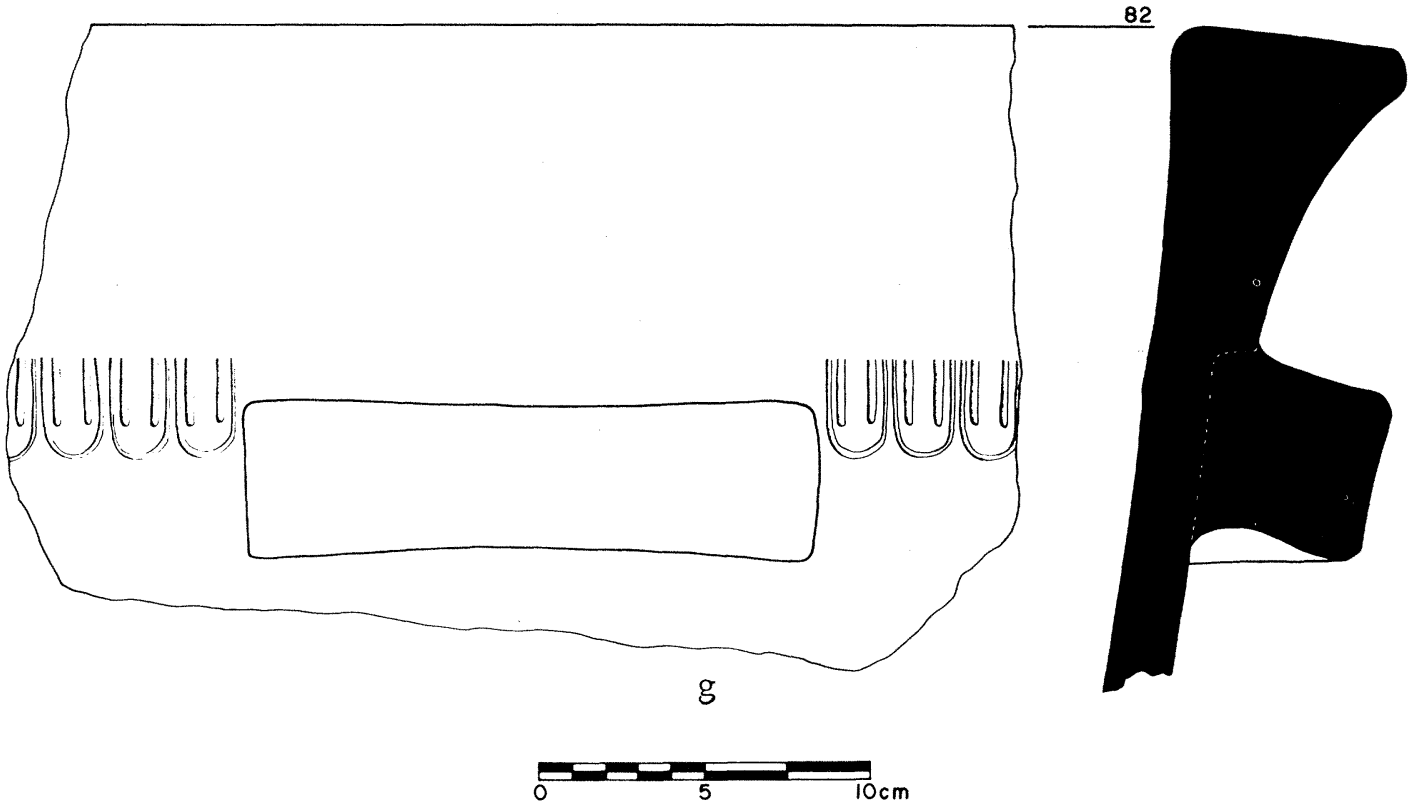

FIg. 25. Survey, ceramics, local wares: a, S 400-2-10; b, S 204-2-441; c, S 4-2-141; d, S 401-2-20; e, S 401-2-20; f, S 9398-2-32; g, S 204-2-172 
Corinthian Type A amphoras; these three impermeable wares may have been developed specially for a local product, perhaps oil. ${ }^{187}$

Roman fine wares are notably rare. Our finds include such overseas imports as Italian sigillata (Fig. 26:a, b) ${ }^{188}$ and African Red Slip wares (Fig. 26:c), ${ }^{189}$ as well as more local products (Fig. 26:d). ${ }^{190}$ Roman and Late Roman coarse wares include dolia (Fig. 26:g), ${ }^{191}$ bowls (Fig. 26:h-j), ${ }^{192}$ cooking pots (Fig. 26:e, f), ${ }^{193}$ and a few identifiable transport amphoras. Part of an arch support for the vaulted firing chamber of a kiln from Site 512 (P1. 97:d) is similar to those in the Roman kiln at Kokkinovrysi west of Corinth and in several such kilns in the province of Elis. ${ }^{194}$ An abundance of Roman sherds and characteristic finger-marked tile at the site confirms the date of the kiln, although it is not clear whether it was used to fire pottery or tile.

Diagnostic Byzantine and Frankish glazed wares include Green and Brown Painted (Pl. 96:e), ${ }^{195}$ Slip Painted (Fig. 27:a, Pl. 96:e), ${ }^{196}$ Measles Ware, Metallic Ware, and those employing sgraffito and techniques of incision (Fig. 27:b, Pls. 96:f, g and 97:e). ${ }^{197}$ A kiln used to fire Middle Byzantine or Frankish glazed pottery was recognized at Site 510 from fragments of hard-baked, coarse, yoke-shaped kiln separators (Fig. 27:c-e) ${ }^{198}$ of a kind used in Byzantine pottery kilns of the 11 th century at Corinth ${ }^{199}$ and fragmentary conical "legs"

${ }^{187}$ Edwards, pp. 144-145; Koehler, 1978 (footnote 179 above), p. 231; Vandiver and Koehler (footnote 179 above), esp. pp. 204-214. I have benefited from discussion of these wares with Professors Carolyn Koehler and Kathleen W. Slane.

${ }^{188}$ Fig. 26:a: S 9413-2-214, from Phlius, Italian sigillata cup (Haltern 12) with mask appliqué. Fig. 26:b: S 7-2-118, Italian sigillata cup rim with applied S-spiral; cf. Slane, 1986 (footnote 173 above), no. 50, p. 285. ${ }^{189}$ S 9413-2-492, from Phlius; cf. J. W. Hayes, Late Roman Pottery, London 1972, pp. 112-118, ARS Form 67 or 68 .

${ }^{190}$ S 7-2-213, Argive plate rim, late Hellenistic to Early Roman; cf. M. Sève, "Un puits argién du hautempire," Études argiénnes (BCH-Suppl. VI), Paris 1980 (pp. 295-321), no. 6, pp. 305-306, fig. 14.

${ }^{191}$ S 7-2-211.

${ }^{192}$ Fig. 26:h: S 9389-2-16, Late Roman folded-rim bowl. Fig. 26:i: S 7-2-123 and Fig. 26:j: S 504-2-127, both of the 5 th century after Christ.

${ }^{193}$ Fig. 26:e: S 7-2-212, Early Roman; cf. Wright, 1980 (footnote 173 above), no. 72, p. 153, fig. 4. Fig. 26:f: S 400-2-33, Late Roman; cf. P. Aupert, "Objets de la vie quotidienne à Argos en 585 ap. J.-C.," Études argiénnes (footnote 190 above, pp. 395-457), nos. 269-285b, p. 433, fig. 43.

${ }^{194}$ S 512-2-75, identified by K. Slane. The kiln at Kokkinovrysi was excavated in 1964 by G. Weinberg; see the brief accounts in G. Daux ("Chronique des fouilles et découvertes archéologiques en Grèce en 1964," $B C H$ 89, 1965 [pp. 683-1007], pp. 689-690) and Megaw ([footnote 178 above] pp. 8-9). For kilns in Elis see H. Schleif and R. Eilmann, "Die Palaestra," in E. Kunze and H. Schleif, IV. Bericht über die Ausgrabungen in Olympia, Berlin 1944 (pp. 8-31), pp. 23-26; J. P. Michaud, "Chronique des fouilles en 1970," BCH 95,

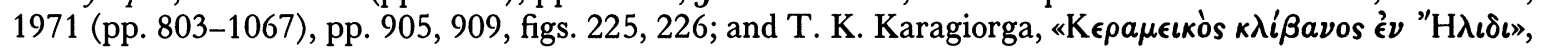
$A A A 4,1971$, pp. 27-32.

${ }^{195}$ S 9388-2-37 (green paint); S 9388-2-46 (green glaze); S 9388-2-47 (green and brown glaze).

${ }^{196} \mathrm{~S}$ 9388-2-51, cup with button base, dotted-style slip painted, green glaze inside and out; cf. C. H. Morgan II, Corinth, XI, The Byzantine Pottery, Cambridge, Mass. 1942, no. 725, p. 244.

197 Pl. 96:f: S 7-2-29; incised sgraffito in the medallion style; cf. ibid., p. 149, fig. 125, probably by the same hand. Pl. 96:g: S 9142-2-182, yellow glaze; S 9142-2-177, strainer, green glaze over white slip; S 9142-2-165, incised sgraffito, green glaze; S 9142-2-179, brown stripes over white slip; S 9142-2-172, sgraffito, green glaze; S 9142-2-175 (Fig. 27:b), incised sgraffito, green glaze. Pl. 97:e: S 7-2-31; incised fish, white slip, yellow-green glaze.

${ }^{198}$ Fig. 27:c: S 510-2-77. Fig. 27:d: S 510-2-79. Fig. 27:e: S 510-2-15.

${ }^{199}$ Morgan (footnote 196 above), pp. 21-22, fig. 17:j-l. 
31

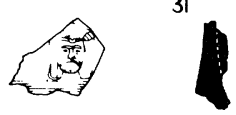

a

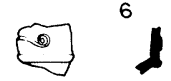

b

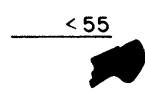

c

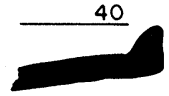

d

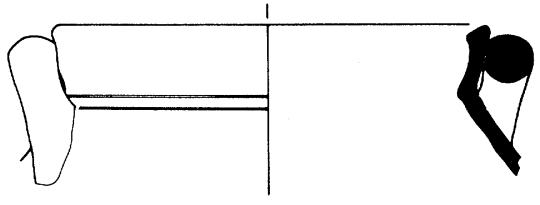

e

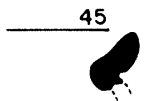

f

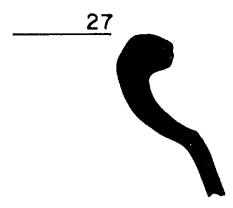

g
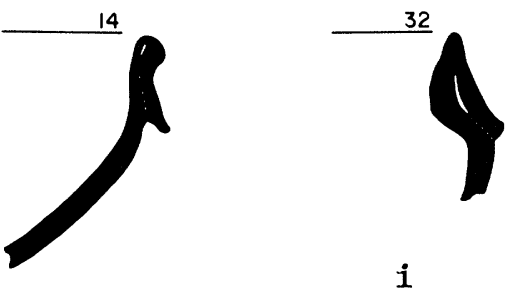

i

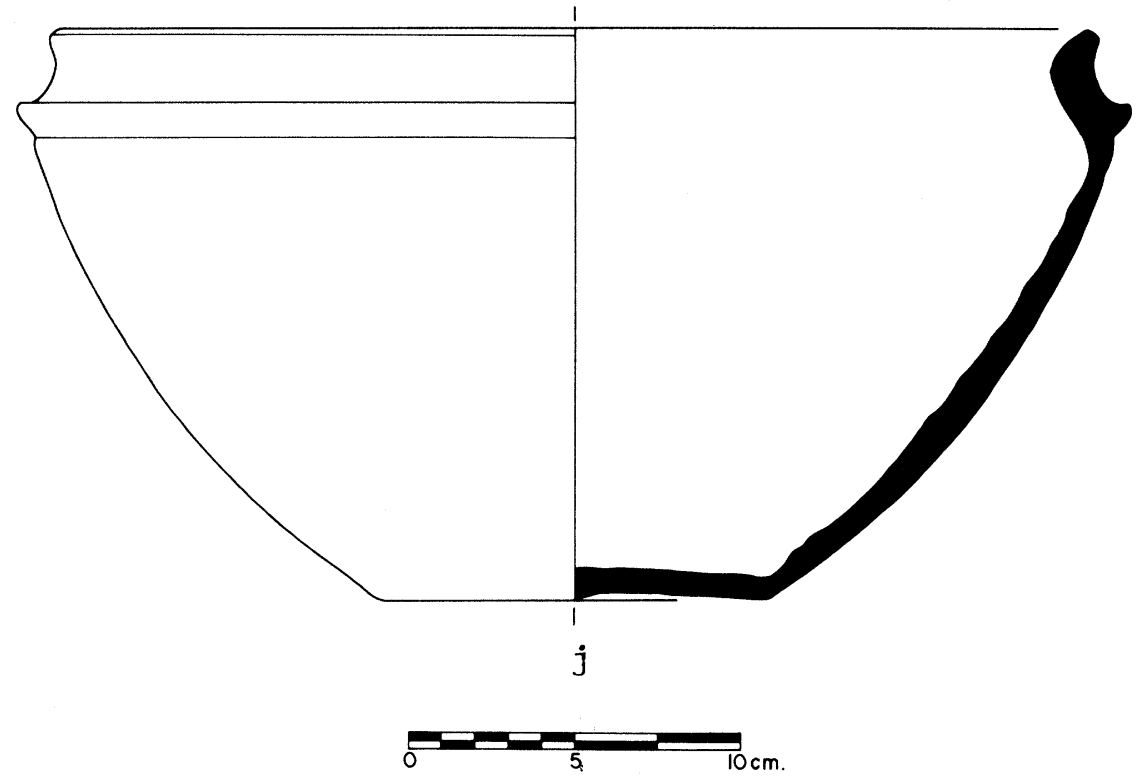

Fig. 26. Survey, ceramics, Roman fine wares: a, S 9413-2-214; b, S 7-2-118; c, S 9413-2-492; d, S 7-2-213. Roman coarse wares: e, S 7-2-212; f, S 400-2-33; g, S 7-2-211; h, S 9389-2-16; i, S 7-2-123; j, S 504-2-127 


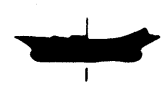

a

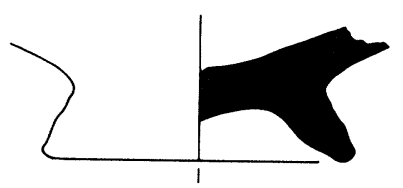

b

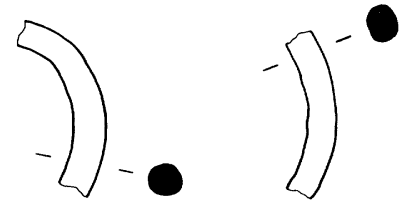

c

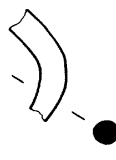

e

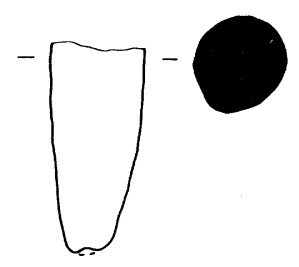

$\mathrm{f}$

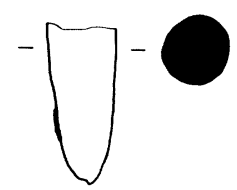

g

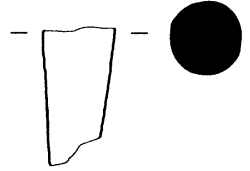

$\mathrm{h}$
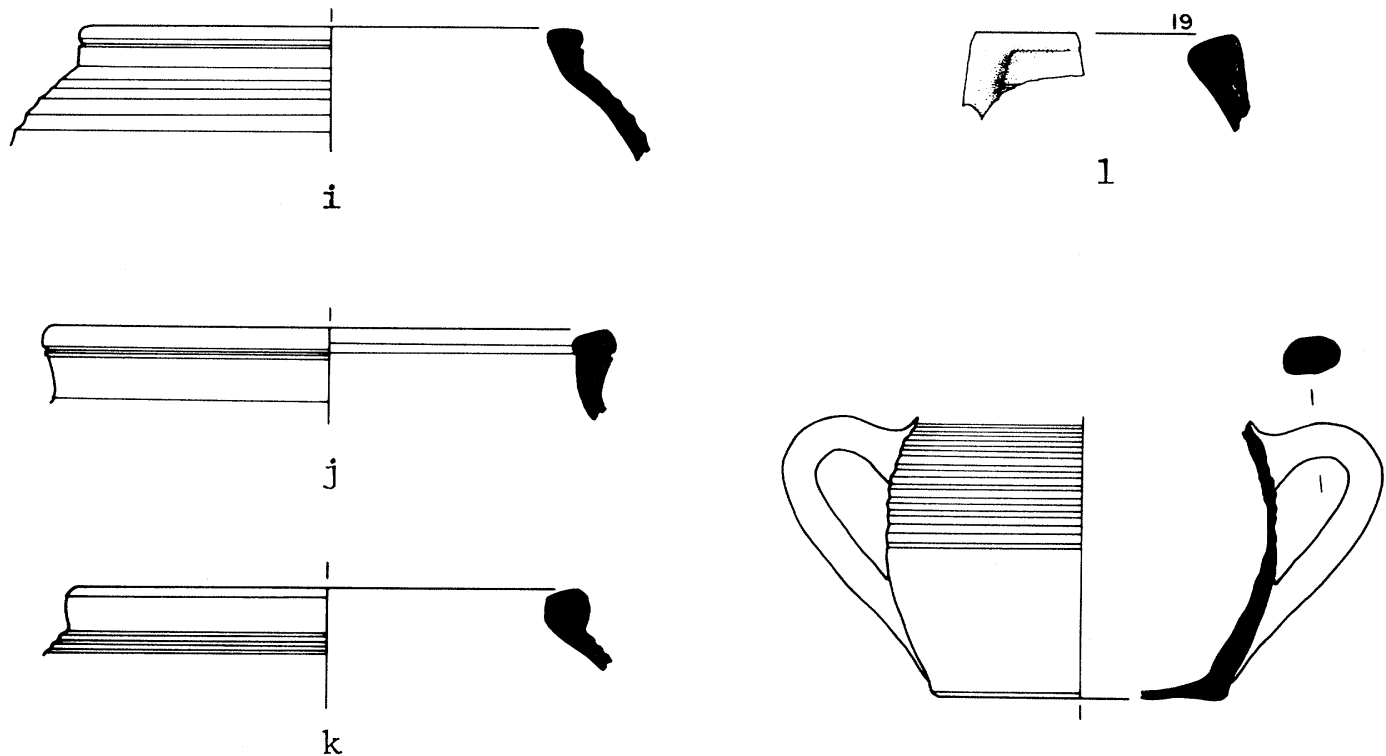

m

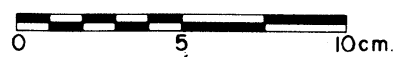

FIG. 27. Survey, ceramics, Byzantine and Frankish: a, S 9388-2-51; b, S 9142-2-175; c, S 510-2-77; d, S 510-2-79; e, S 510-2-15; f, S 510-2-43; g, S 510-2-108; h, S 9388-2-28; i, S 502-2-76; j, S 9339-2-17; k, S 203-2-103; 1, S 7-2-308; m, S 9110-2-3 
of the same fabric to which small patches of glaze occasionally adhere (Fig. 27:f-h, Pl. 96:e, bottom); ${ }^{200}$ the latter must be kiln supports, and similar pieces were recently excavated in Mediaeval kiln debris at Corinth. ${ }^{201}$ Glazed sherds (Pl. 96:e, top) which might have been made in the kiln include slip-painted fragments in the dotted and linear styles, Green and Brown Painted, and fine and wide sgraffito styles, all with close parallels at Corinth. ${ }^{202}$ Byzantine and Frankish matt-painted wares are found, including monochromatic (Pl. 97:f $)^{203}$ and polychromatic (Pl. 96:h) ${ }^{204}$ varieties, the latter employing red and white as well as the more common black paint on a smooth red ground. Middle Byzantine cooking pots are among the most abundant and diagnostic finds (Fig. 27:i-m; Pl. 96:e, top). ${ }^{205}$

In summary, preliminary analysis of ceramic finds indicates that during the historic period the region around Nemea depended primarily on Corinth, Argos, and other near-by or strictly local centers for most of its ceramic materials. Imports are strikingly rare in all periods, a pattern that seems to hold equally for fine wares, coarse wares, and transport amphoras. The survey has produced important evidence of local production throughout this long period. That Phlius produced its own pottery and figurines during the Archaic and Classical periods is indicated by the distinctive fabric and style of materials from the new votive deposit there; kiln debris of the Roman and Mediaeval periods provides indisputable evidence for local production at several sites in the region during later times. Local affinities are observed in the region's fondness for blister ware during the Classical and Hellenistic periods, whether or not that distinctive ware was manufactured there or brought in from Corinth and Argos or other near-by centers.

At this time it is not possible to differentiate between rural and urban use of pottery within the area except to observe greater diversity at Phlius and other large centers. When viewed as a region, however, our discoveries stand out, especially when compared with results of similar surveys in other parts of Greece, notably on the island of Keos and in the Southern Argolid. While distance from the sea and the difficulty of overland transport might help explain why the inland region received relatively fewer imports during historic times than these island or coastal areas, no doubt other factors played a role in the apparent isolation of the Nemea region. ${ }^{206}$ This geographical factor may be illustrated by contrasting

${ }^{200}$ Pl. 96:e, bottom: S 9388-2-28, S 9388-2-78, S 9388-2-72, S 9388-2-74. Fig. 27:f: S 510-2-43. Fig. 27:g: S 510-2-108 (glaze adhering to the side). Fig. 27:h: S 9388-2-28.

${ }^{201}$ Excavated in 1986; I am grateful to Dr. C. K. Williams, II for bringing this material to my attention and allowing me to examine it briefly during its initial processing.

${ }^{202}$ Pl. 96:e, top: S 9388-2-37; S 9388-2-46; S 9388-2-47; S 9388-2-51; S 9388-2-76; cf. Morgan (footnote 196 above), pp. 95-103.

${ }^{203}$ S 9134-2-1; cf. T. S. MacKay, "More Byzantine and Frankish Pottery from Corinth," Hesperia 36, 1967 (pp. 249-320), pp. 279-288; M. Piérart and J.-P. Thalmann, "Céramique romaine et médiévale," Études argiénnes (footnote 190 above), nos. B37 and B41, p. 480; nos. D9, D10, and D11, p. 482.

${ }^{204}$ S 9556-2-75 and S 9556-2-76; cf. MacKay (footnote 203 above), nos. 64, 70-72, p. 280.

${ }^{205}$ Fig. 27:i: S 502-2-76, rim. Fig. 27:j: S 9339-2-17, rim. Fig. 27:k: S 203-2-103, rim. Fig. 27:1: S 7-2-308, rim with attached lugs. Fig. 27:m: S 9110-2-3, lacking rim. Pl. 96:e, top: S 9388-2-60. For the group cf. MacKay, op. cit., pp. 288-300.

${ }^{206}$ Sutton in Cherry et al., Archaeological Landscape; Sutton in Munn, Pullen, and Runnels (footnote 63 above). 
the dearth of transport amphoras other than Corinthian in the Nemea region during the first millennium B.c. with their relative abundance on Keos. The survey of northwestern Keos yielded a large number and variety of amphoras during this period, but the islanders, living in an area of restricted natural resources, were highly dependent upon imports for their survival. The richer and more diverse natural resources of the Nemea region may have provided a base of self-sufficiency that did not require heavy dependency on external areas. This of course is an issue that has been of general interest to the project as a whole and cannot be answered merely by study of the ceramic finds from the survey. That such questions, however, among others, can be defined and explored in this preliminary study well illustrates the utility of systematically gathering and studying surface collections.

INDIANA UNIVERSITY

ROBERT F. SUtTon, JR.

Department of Classical Studies

Cavanaugh Hall 501B

425 University Blvd.

Indianapolis, IN 46202-5140 


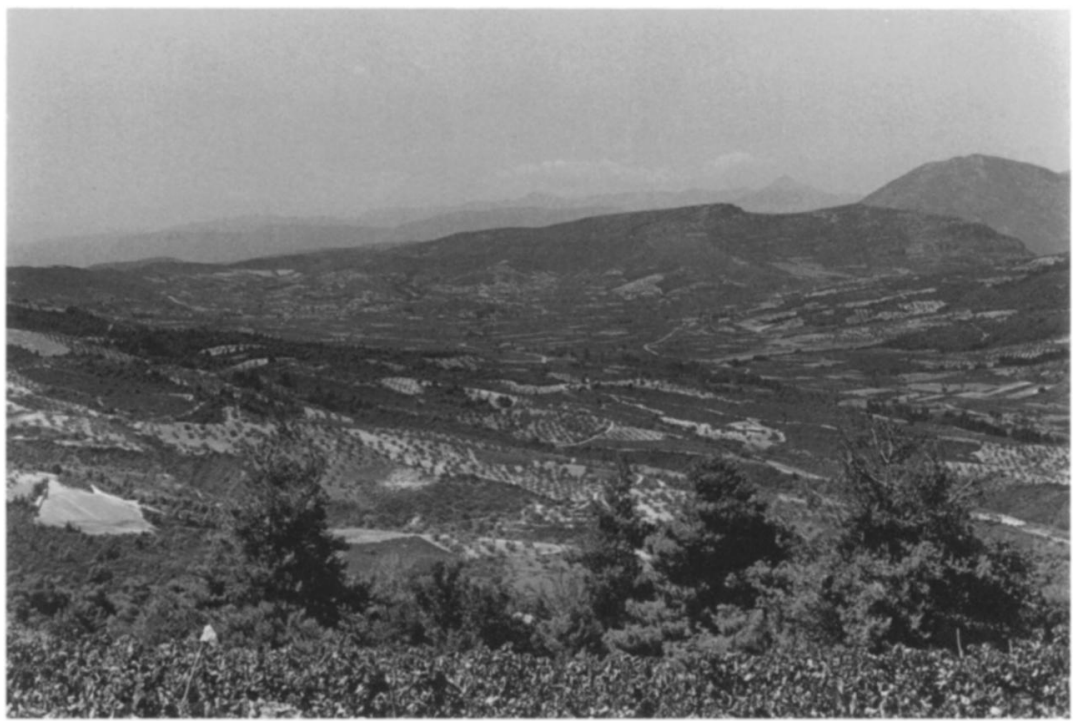

a. View of the Nemea Valley from the northeast, taken from Mt. Phoukas

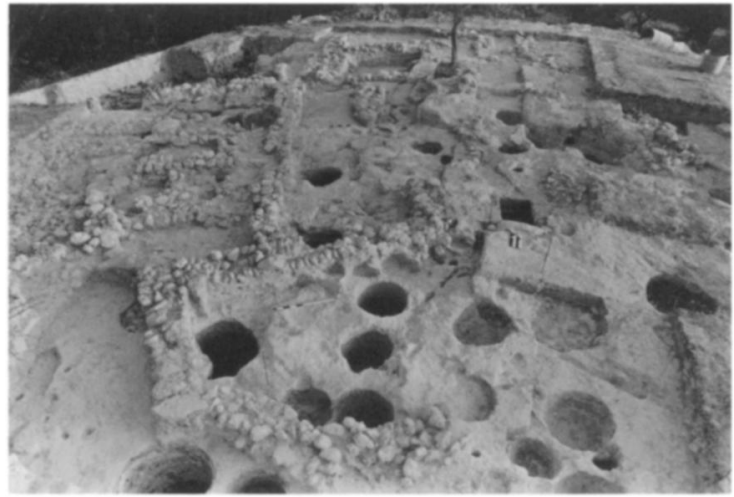

b. Tsoungiza, view of EU5 from south

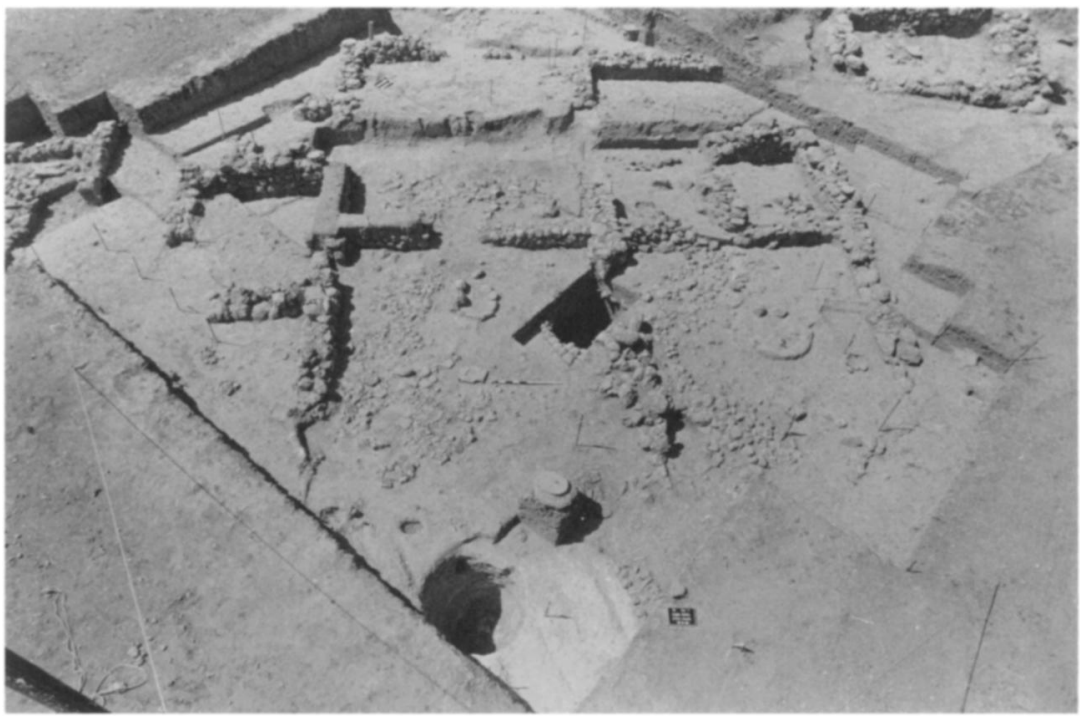

c. Tsoungiza, view of EU7 from south

James C. Wright et al:: The Nemea Valley Archaeological Project 


\section{PLATE 94}

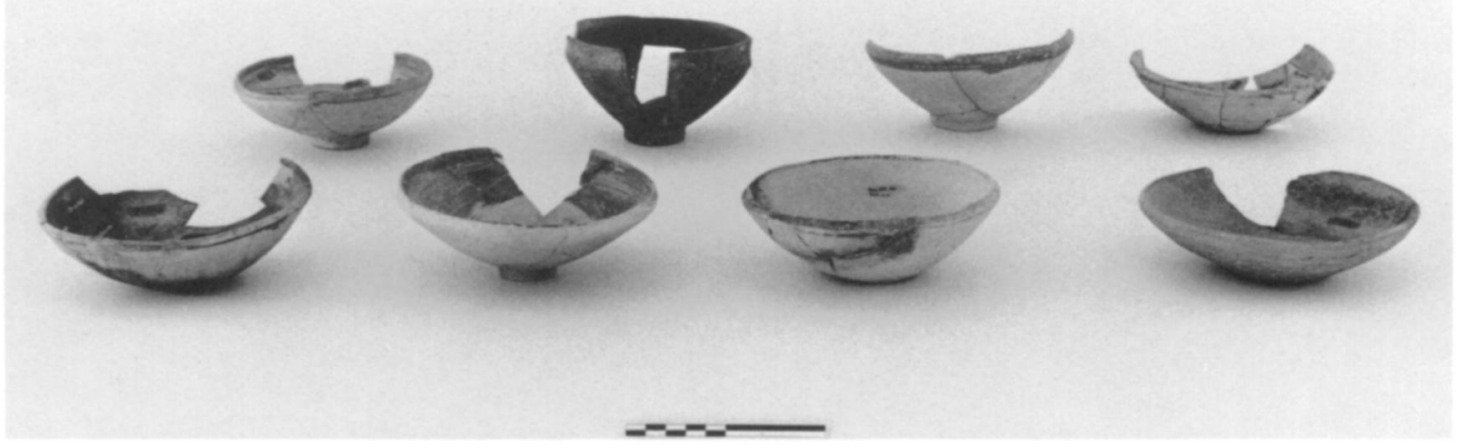

a. EU5, "burnt room" at north, bowls from floor. Top: 757-2-4, 757-2-6, 757-2-7, 757-2-5.

Bottom: 757-2-9, 757-2-10, 757-2-2, 757-2-8

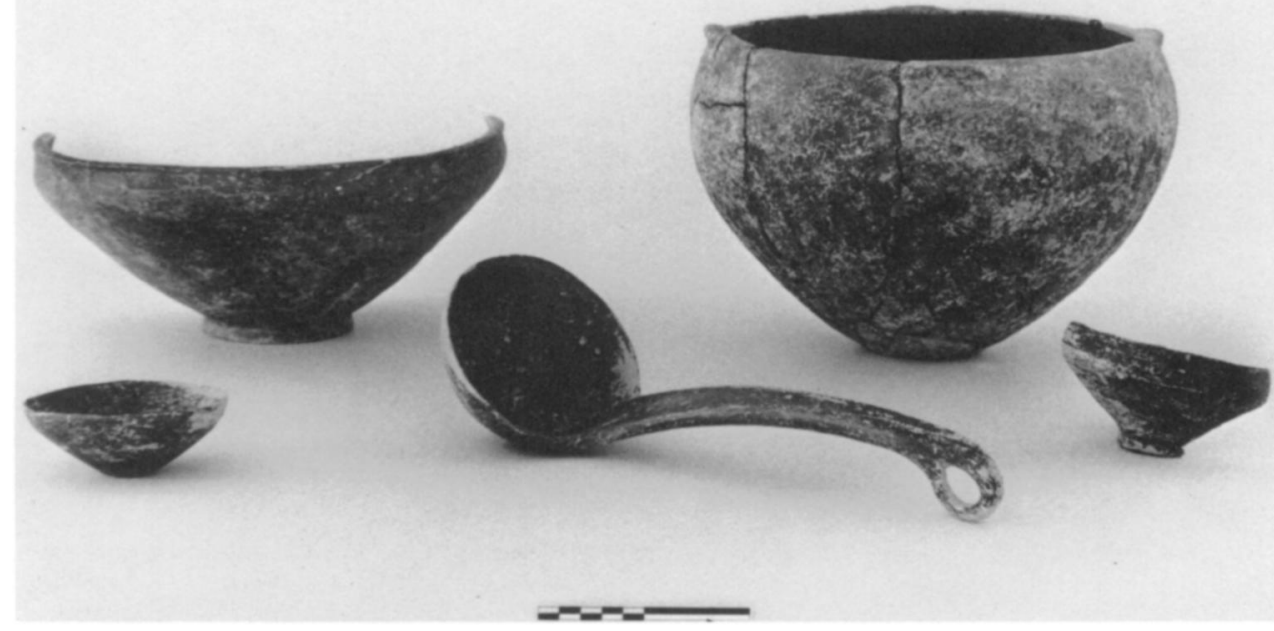

b. EU5, Pit 56, vessels. Top: 1948-2-4, 1948-2-1. Bottom: 1948-2-3, 1948-2-2, 1948-2-5

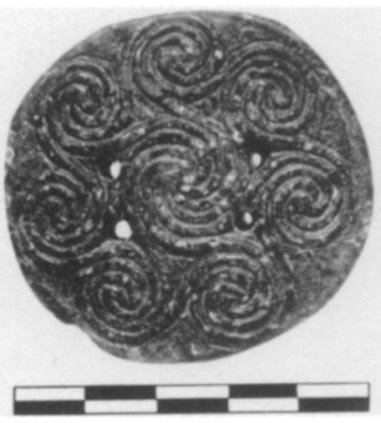

c. EU5, lid of steatite vessel 745-8-1

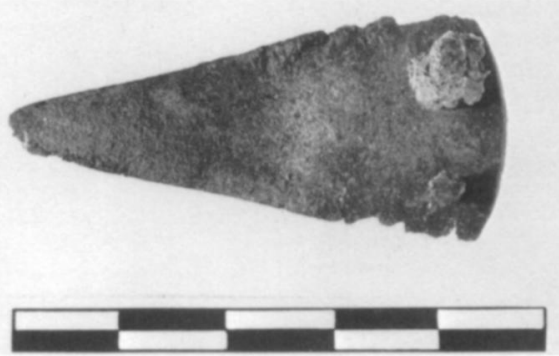

d. EU5, bronze dagger 2016-5-1
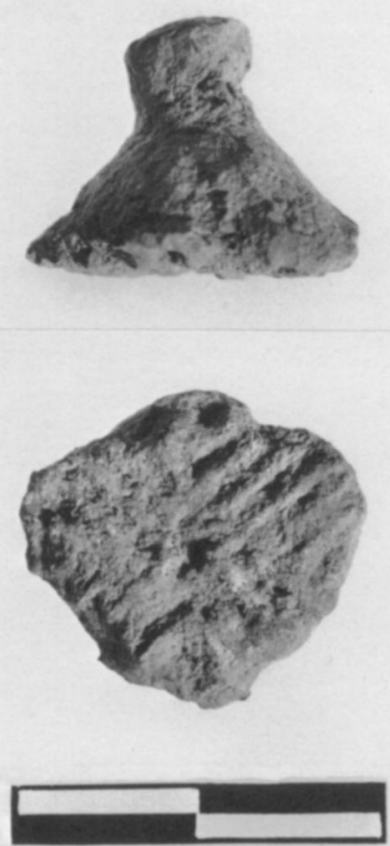

e. EU5, lead stamp 890-5-1
Tsoungiza

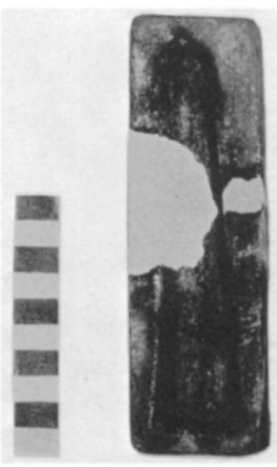
archives)

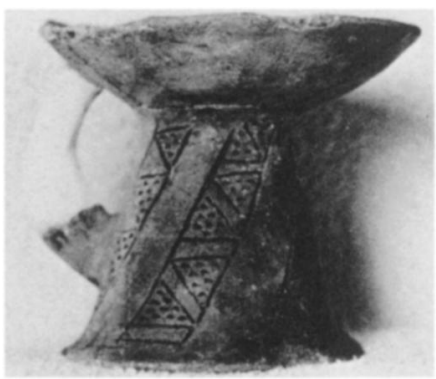

g. EU5 (Trench P, the "well", 1927), incised pedestal-footed shallow cup (photo Harland archives) 
PLATE 95

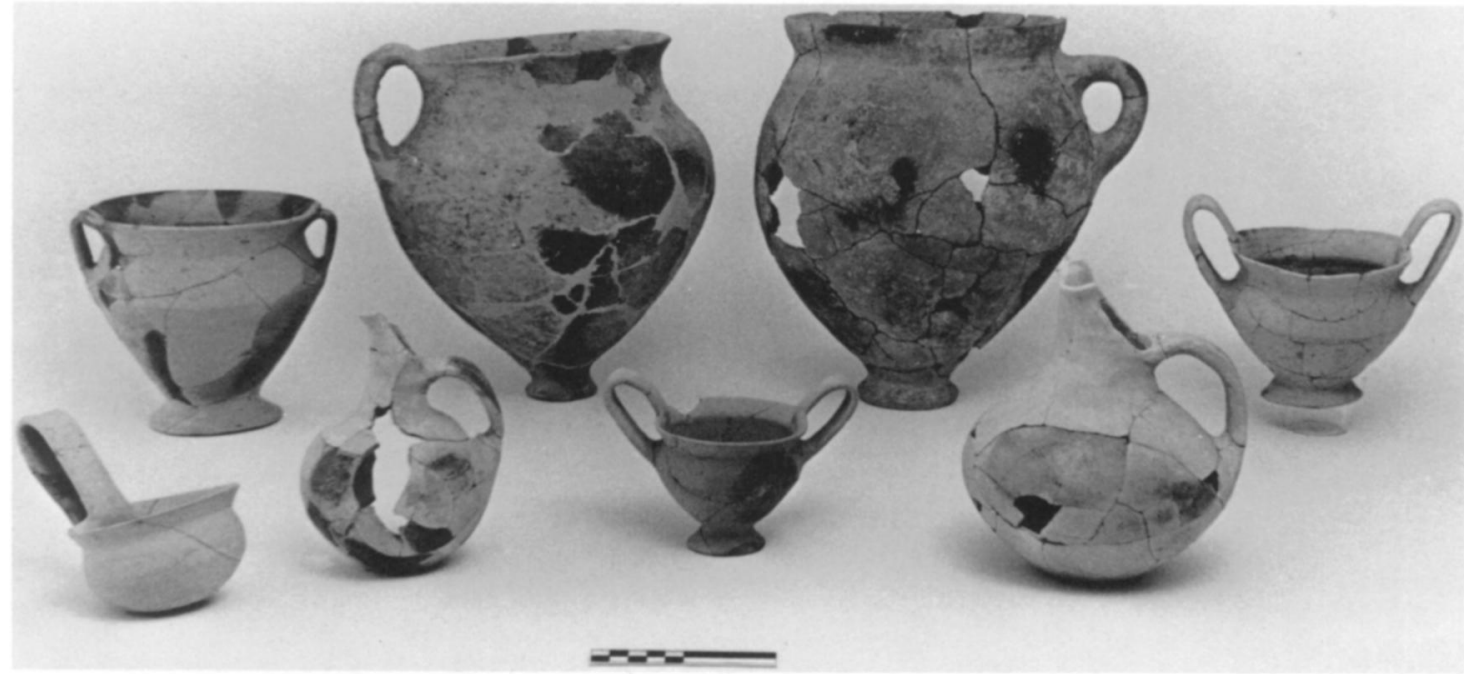

a. $\mathrm{EU1}=\mathrm{EU} 7$, floor deposit from front room of southwestern building.

Top: P 716, P 724, P 740, P 722. Bottom: P 741, P 723, P 708, P 685
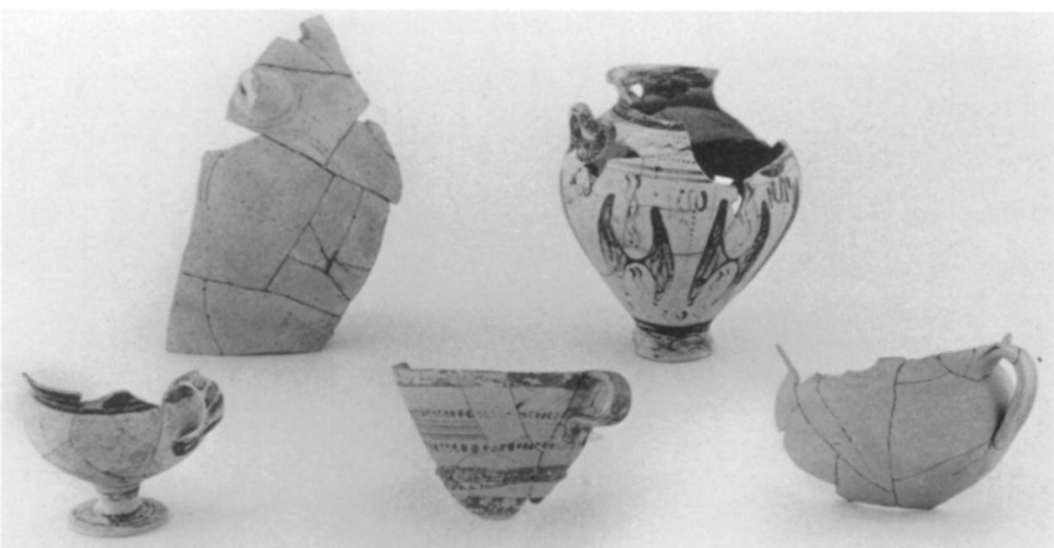

b. EU10, LH IIA deposit. Top: 1767-2-3, 1759-2-2. Bottom: 1774-2-2, 1776-2-1, 1767-2-1

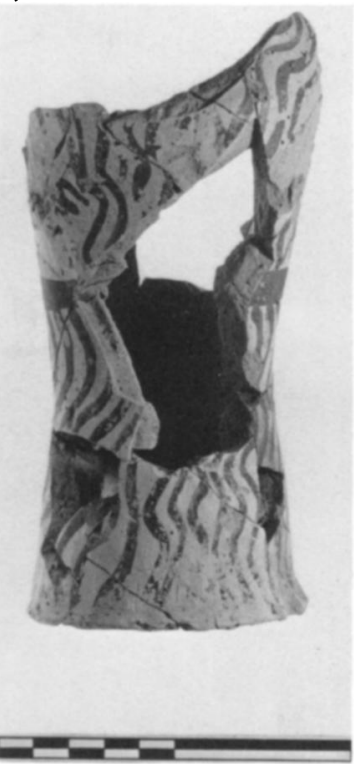

e. EU9, fragment of figure 1581-2-1
Tsoungiza

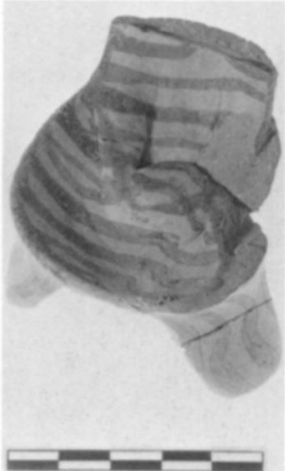

f. EU9, "breadmaker" figurine 1559-2-1
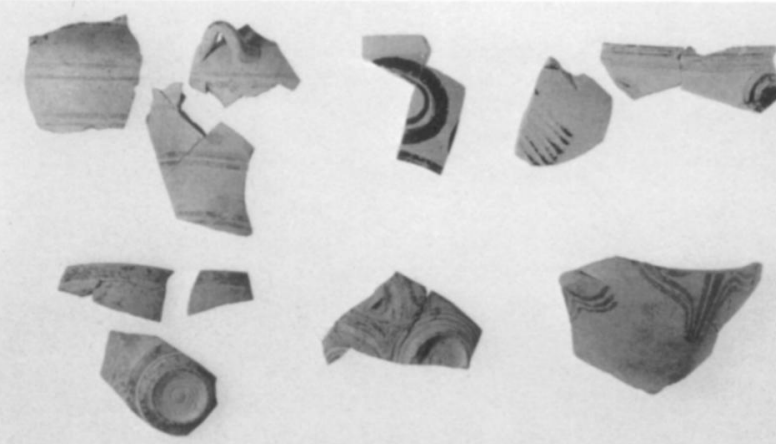

c. EU2, floor deposit. Top: 308-2-9, 309-2-3, 308-2-10. Bottom: 308-2-7, 308-2-12, 308-2-3

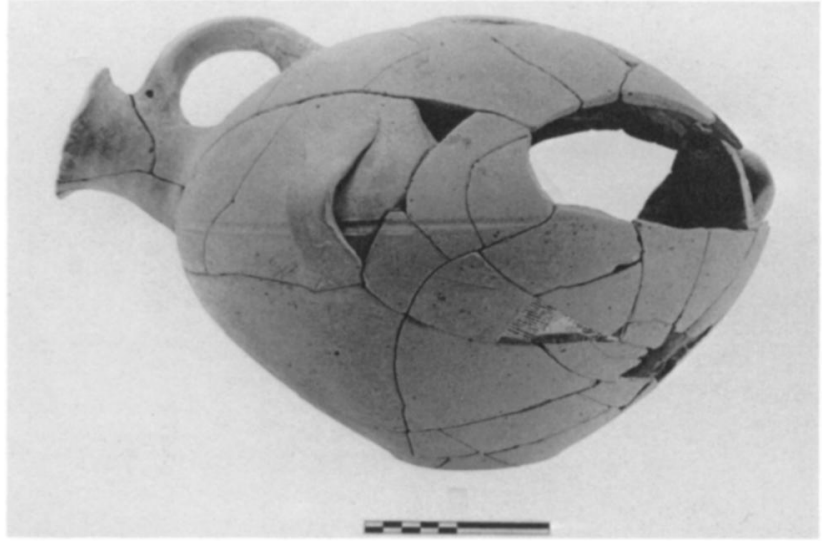

d. EU2, floor deposit: askos 223-2-2 
PLATE 96

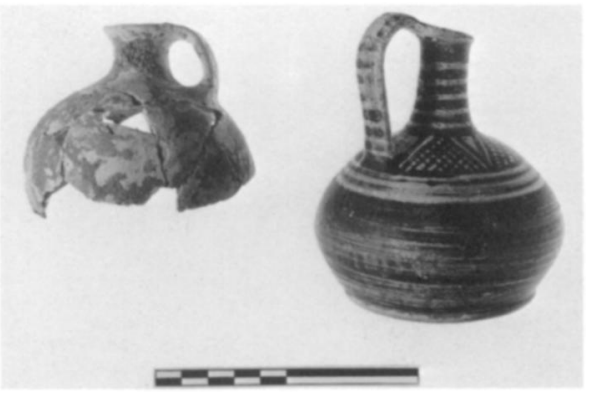

a. S 9413-2-476, S 9413-2-468

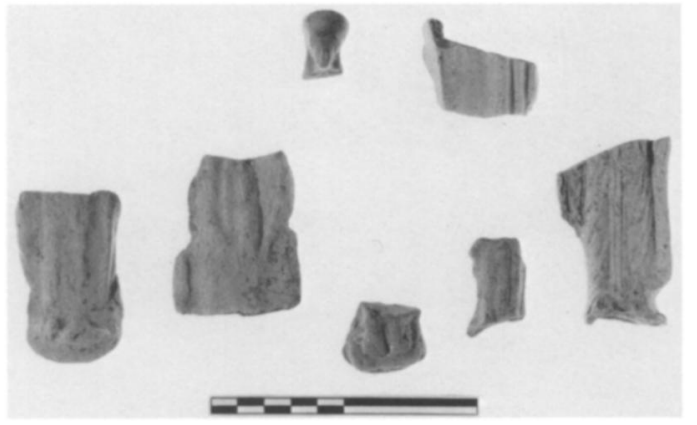

c. Top: S 9413-2-307, S 9413-2-288.

Bottom: S 9413-2-292, S 9413-2-306,

S 9413-2-284, S 9413-2-313, S 9413-2-142
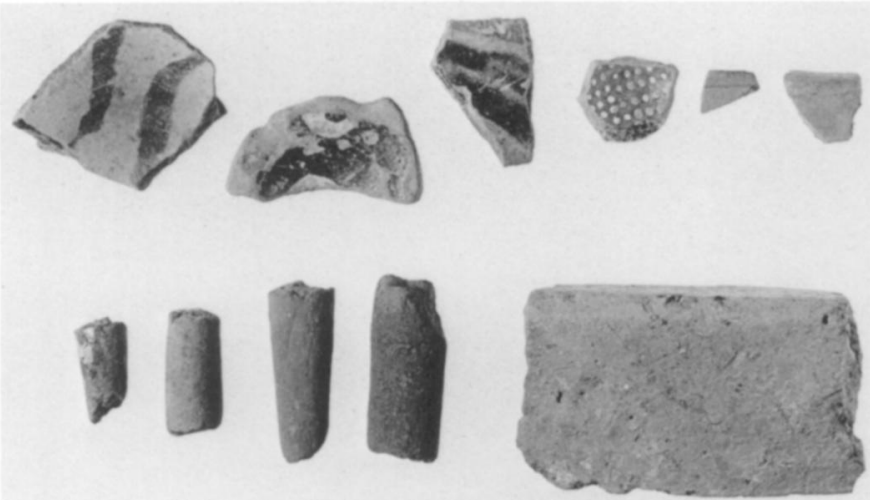

e. Top: S 9388-2-37, S 9388-2-46, S 9388-2-47, S 9388-2-51, S 9388-2-76, S 9388-2-60. Bottom: S 9388-2-28, S 9388-2-78, S 9388-2-72, S 9388-2-74, S 9388-2-6

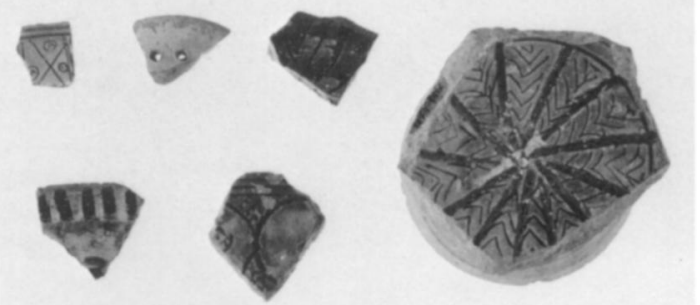

g. Top: S 9142-2-182, S 9142-2-177, S 9142-2-165, S 9142-2-175.

Bottom: S 9142-2-179, S 9142-2-172

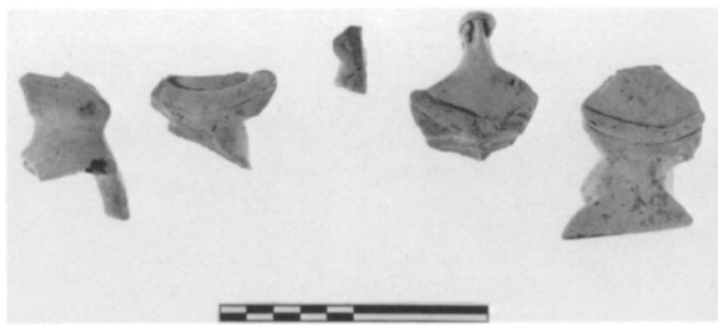

b. S 9413-2-287, S 9413-2-305, S 9413-2-280, S 9413-2-309, S 9413-2-301

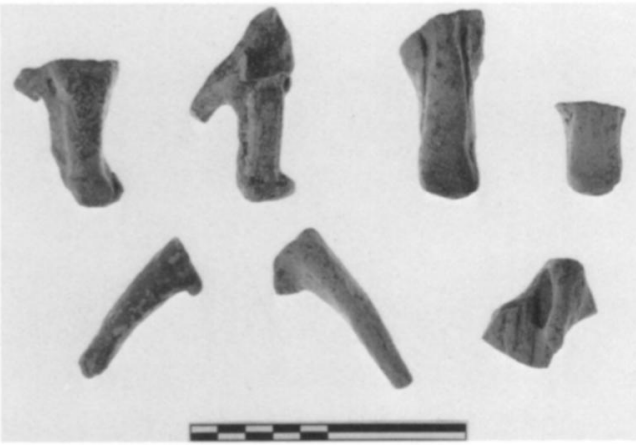

d. Top: S 9413-2-300, S 9413-2-310, S 9413-2-295, S 9413-2-187.

Bottom: S 9413-2-319, S 9413-2-293, S 9413-2-290

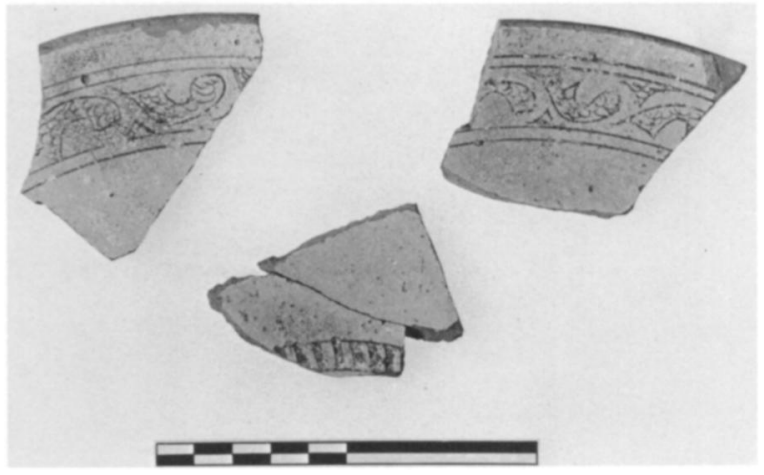

f. S 7-2-29
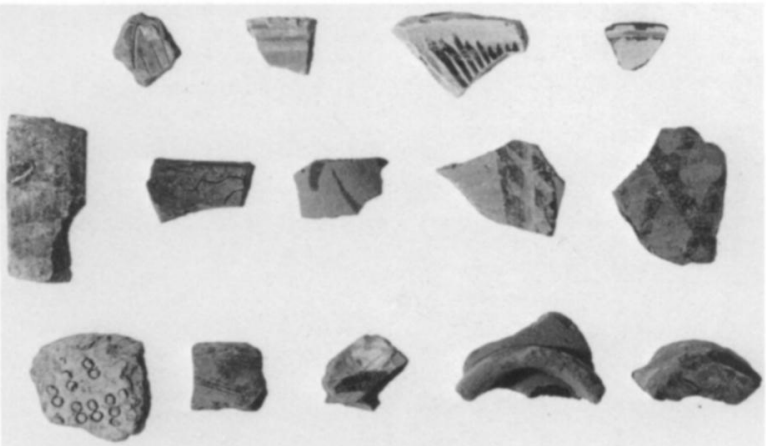

h. Top: S 9556-2-19, S 9556-2-28, S 9556-2-47, S 9556-2-20. Middle: S 9556-2-23, S 9556-2-50, S 9556-2-73, S 9556-2-75, S 9556-2-76.

Bottom: S 9556-2-65, S 9556-2-29, S 9556-2-17, S 9556-2-23, S 9556-2-26

James C. Wright et al: The Nemea Valley Archaeological Project 

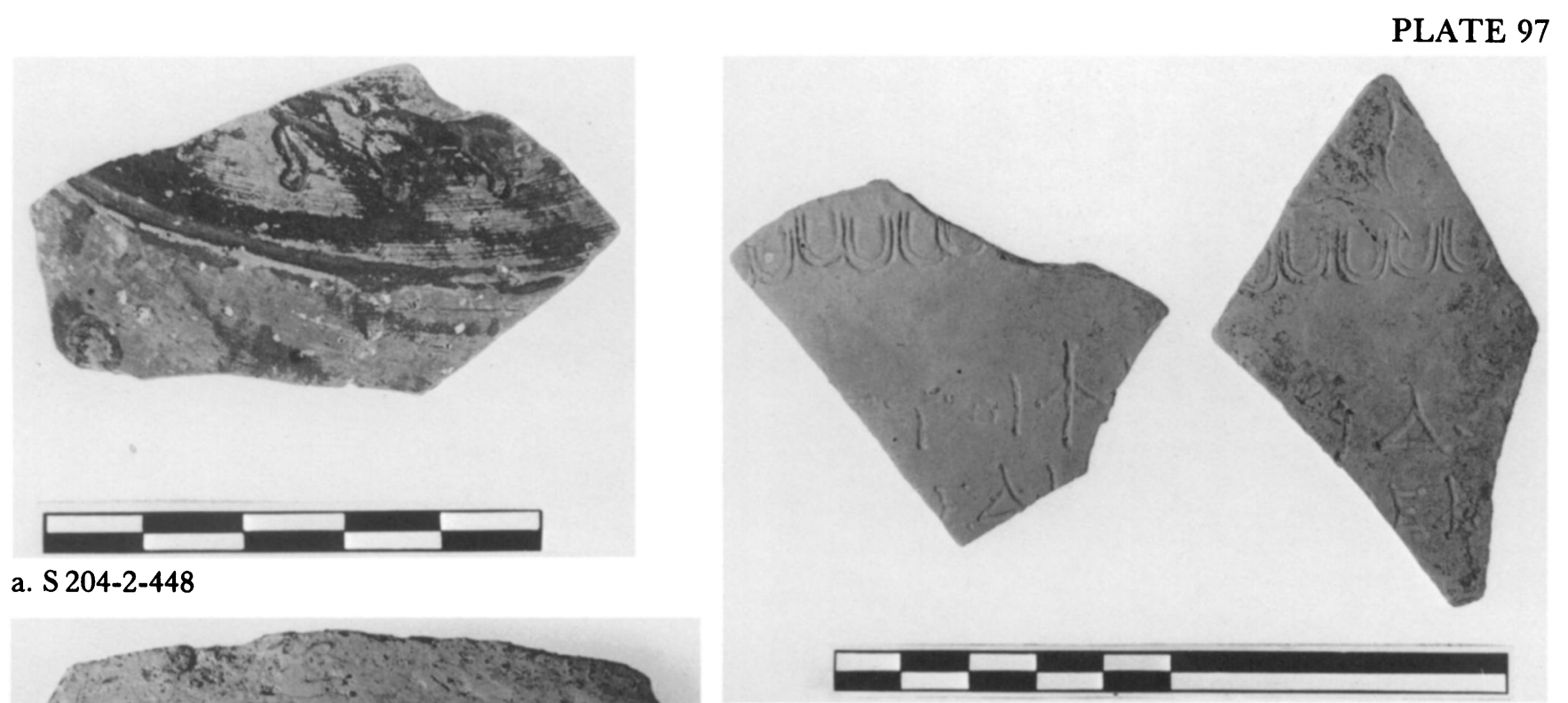

a. S 204-2-448

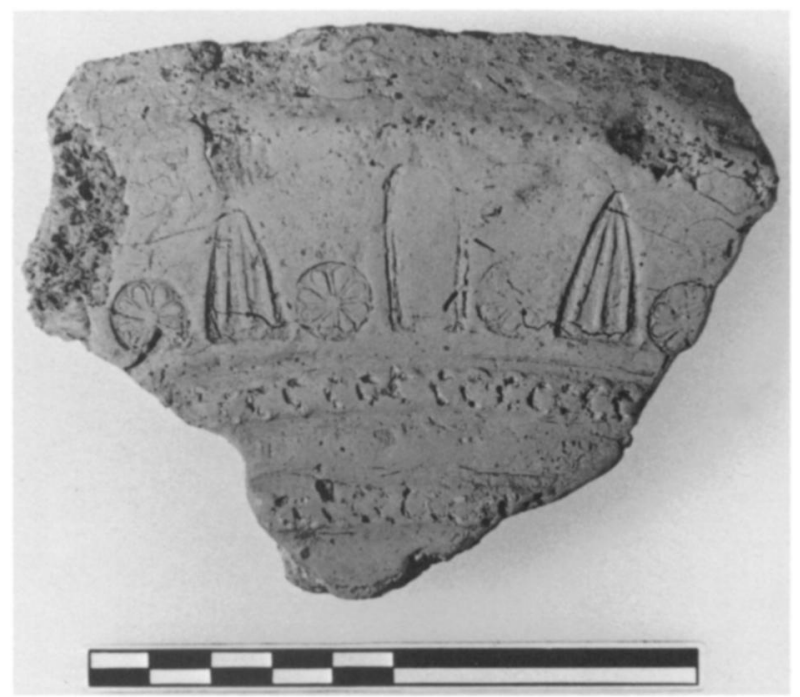

b. Left: S 904-2-1. Right: S 904-2-2
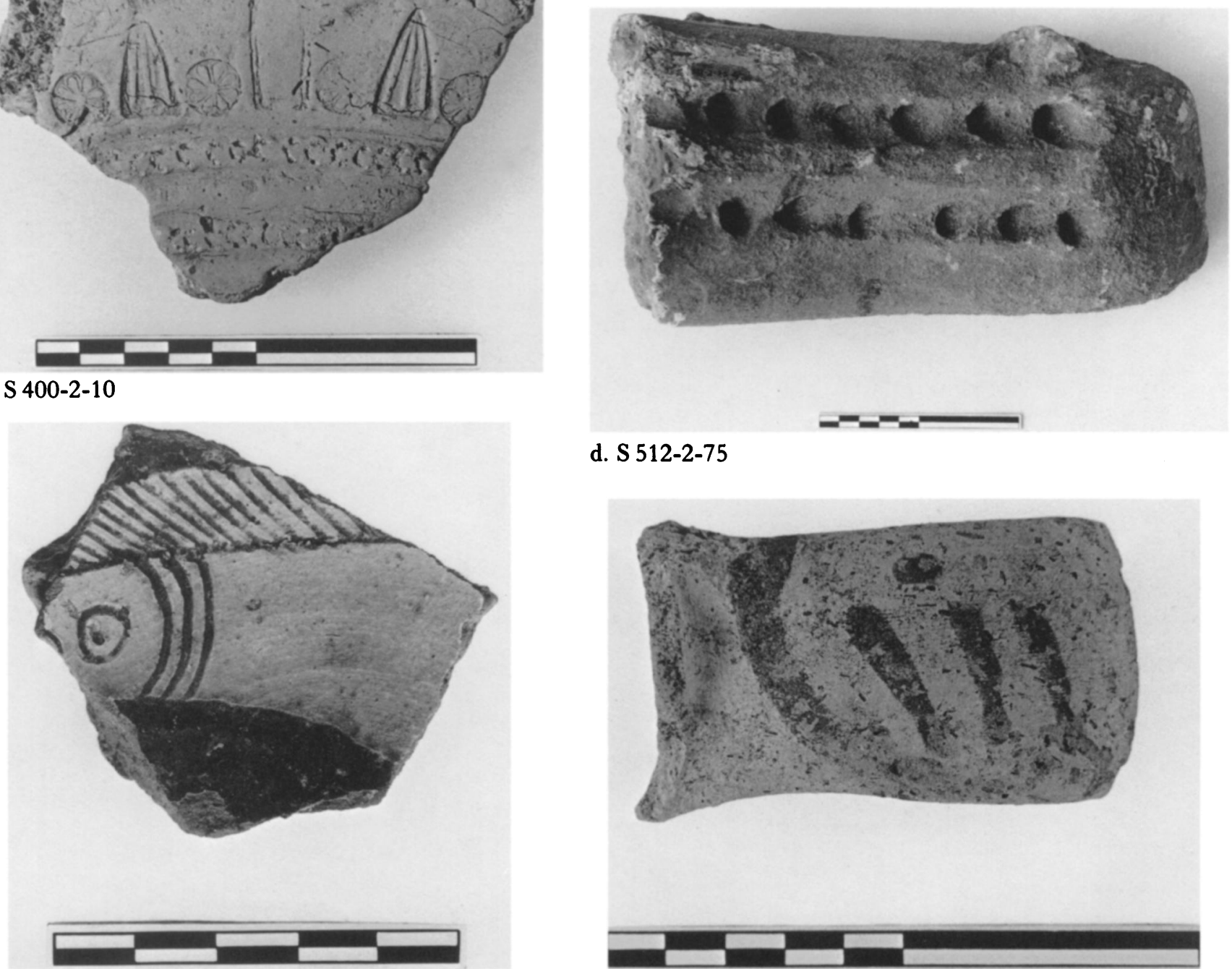

d. S $512-2-75$

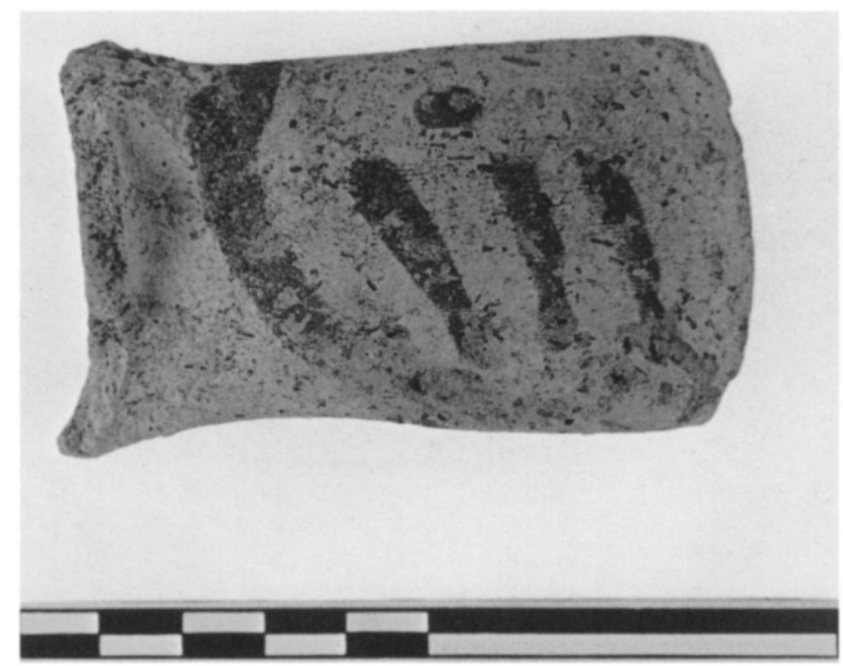

e. S 7-2-31

f. S 9134-2-1

James C. Wright et al.: The Nemea Valley Archaeological Project 